\title{
THE END OF THE SEA WALL
}

SHANNON MCSTAY 2017

A 120 point thesis submitted to the Faculty of Architecture and Design, Victoria University of Wellington, in partial fulfilment of the requirements for the degree of Master of Architecture (Professional) 


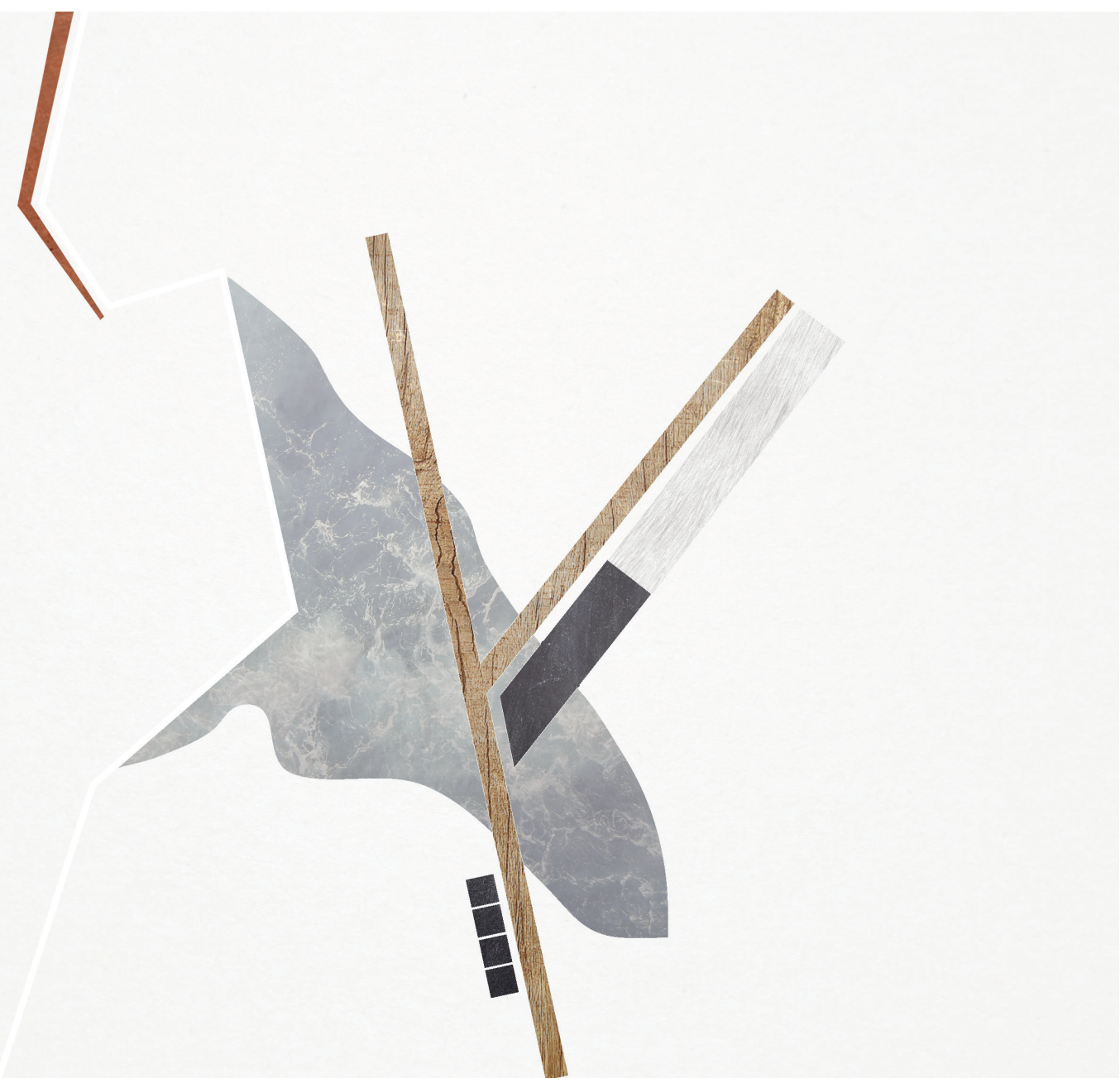

Layout collage 1.

Collaged image explores potential relationship between sea wall, wetlands and built form. Looks at how the building masses might sit alongside the boardwalk system. 
Dad, for being at the receiving end of my meltdowns.

And lastly Mum, my guardian angel, I'm sure it was an entertaining view from up there. 


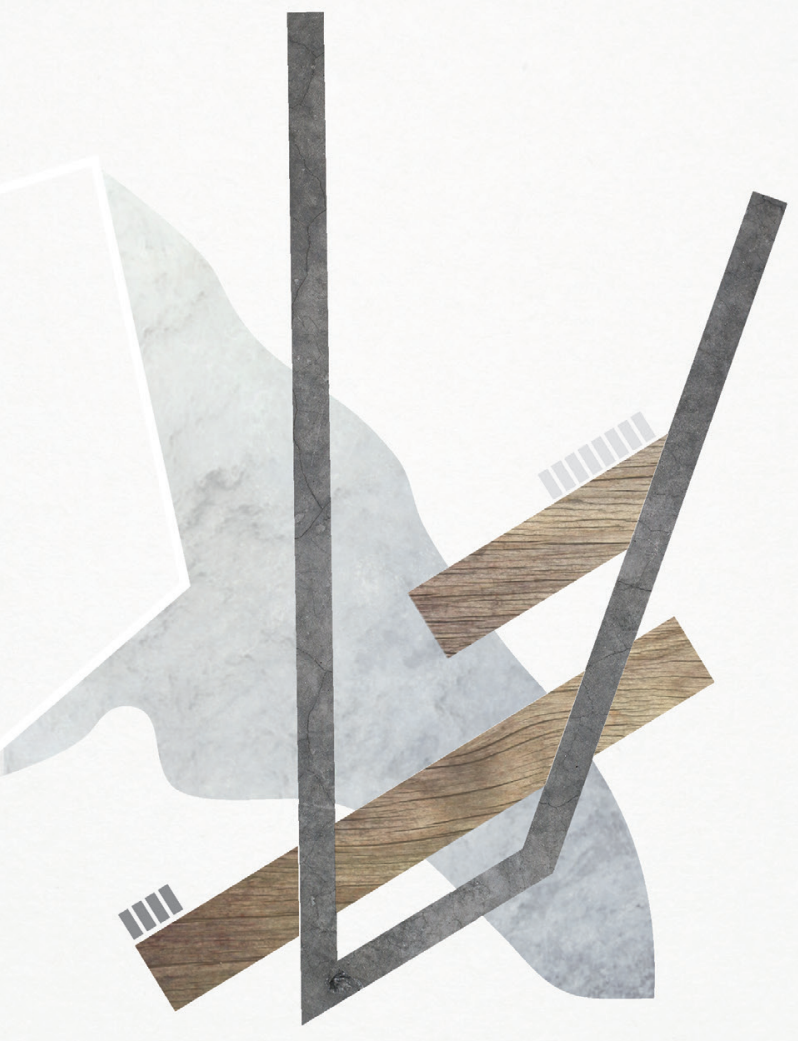

Layout collage 2

Collaged image explores possible relationship between built form and boardwalk system. In this iteration, the boardwalk system runs through the building masses, encouraging visitors to engage with the spaces. 
FIGURE 3

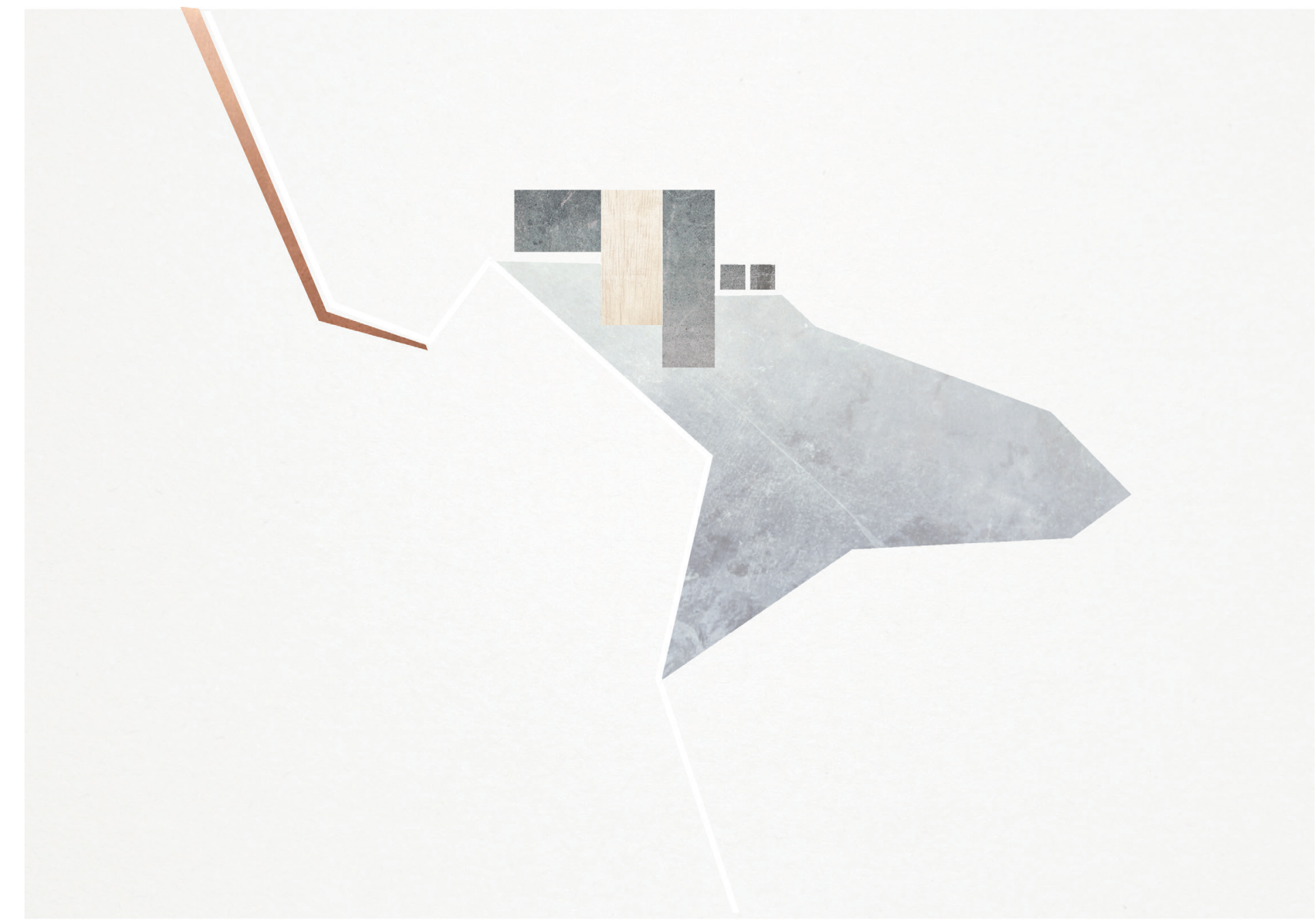

Layout collage 3.

Collaged image looks at relationship between built form and wetland system. Explores having the built form sitting on the edge of the dunes over wetlands.

However without the boardwalk system, the relationship between the building and wetlands is compromised. 
FIGURE 4

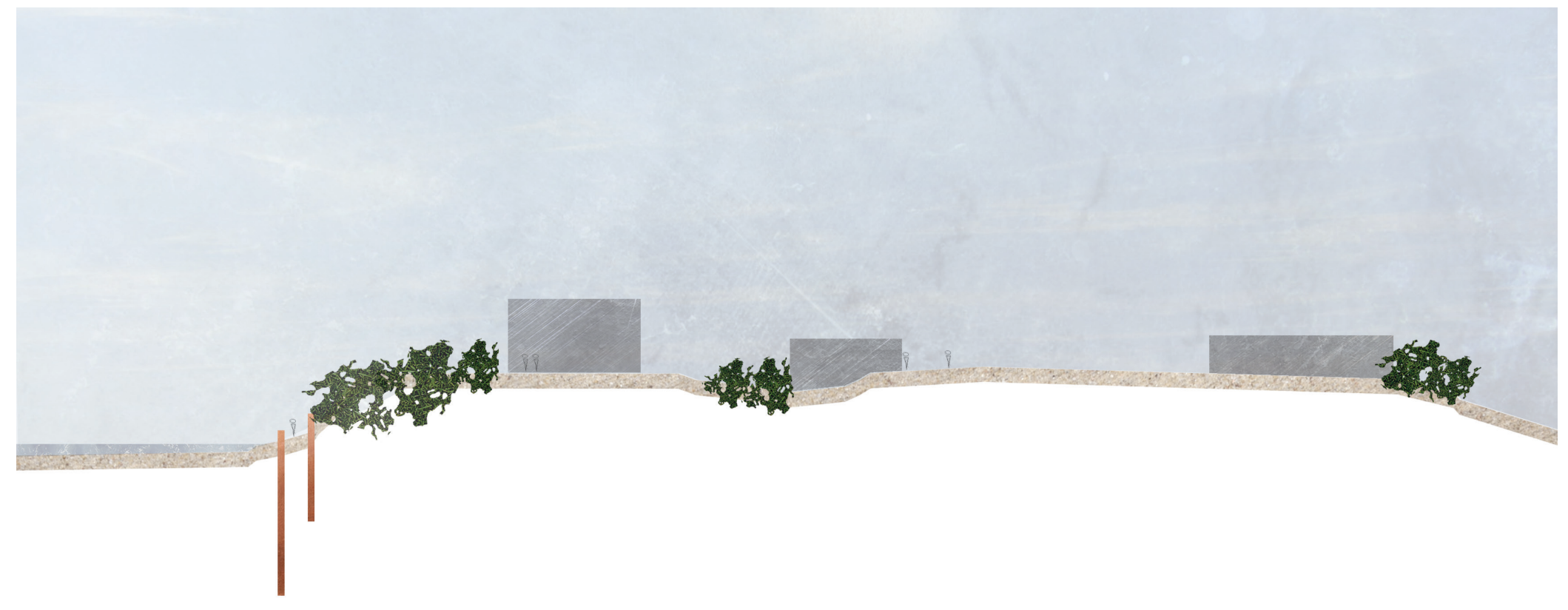

Section of site.

Section view through existing site at Raumati

South. Shows how

planting and sea wall are

relied on to retain land. 
With climate change becoming more widely understood, we are beginning to see how this phenomenon is impacting on our ability to live coastally. Coastal properties represent some of the most expensive real estate in the country, however these properties are being battered by increasing storm surges causing coastal erosion and decay to the land on which they sit. This is resulting in people fighting to keep their homes out of the water, along with an increasing need for a solution to keep the water out of their homes. In Raumati, sea walls began appearing in the 1950s with people blocking their individual properties from the ocean with wooden log walls. These walls have continued to get larger, higher and more solid until they have become the rock accumulation, stone path and concrete walls that stand today along almost the entire length of the Kapiti Coast.

The impact of such walls is that, while they protect the land immediately behind them, they cause greater issues further down the coast, causing sections of the coastline to deteriorate at a far more accelerated rate. The aim of this project will be to put an end to the Kapiti sea wall by addressing the site at the southern end of Raumati where this erosion is becoming increasingly evident. Here, the delicate sand dunes are being eaten away by heightened storm surges and an ever-increasing sea level.

Rather than looking at it as a negative effect, this thesis will explore the opportunities that are opened by this decay. The project proposes the reinstating and re-wetting of the once drained wetlands that lie behind the natural dunes. Above these wetlands, a ranger's hut will act as a home, embassy and church within Queen Elizabeth Park. This allows for a greater sense of custodianship, with more people coming, going and staying within the park. The project outcome will be a building that combines public and private spaces. It will allow for the fluctuation in sea levels to interact with and become a part of the building, rather than being excluded through traditional approaches to dealing with climate change on coastlines. Hence, this ranger's hut will put an end to the sea wall. 


\begin{tabular}{|c|c|}
\hline Abstract & 7 \\
\hline Introduction & 11 \\
\hline Aims \& objectives & 13 \\
\hline Scope \& limitations & 15 \\
\hline Focus & 15 \\
\hline Methodology & 17 \\
\hline Research question & 19 \\
\hline The Project & 23 \\
\hline The site & 25 \\
\hline Challenges & 27 \\
\hline Strategies & 31 \\
\hline Precedents & 35 \\
\hline The Design Part 1: Wetlands & 41 \\
\hline Response to site & 45 \\
\hline History & 47 \\
\hline Role of wetlands & 49 \\
\hline Reinstatement & 51 \\
\hline Vegetation & 53 \\
\hline
\end{tabular}


The Design Part 2: Ranger's Hut

Ranger's Hut as Home 60

The family 63

Public \& private

Community home

Ranger's Hut as Embassy 74

Custodianship

Hosting 79

Learning 85

Gateway

Ranger's Hut as Church 94

Meeting place 97

Celebrating history

A new relationship

Sustainability

Conclusion 111

The Process 113

Bibliography 149

List of Figures 152 


\section{INTRODUCTION}

In New Zealand, there is a huge desire to live coastally, with waterfront homes being amongst the most expensive real estate. However, these homes are some of the most at risk of collapse, as storm surges and a rising sea level batter the coastline. In order to prevent this, people build sea walls. Unfortunately, while sea walls protect the land directly behind them, they only accelerate the erosion further down the coastline.

Situated between the settlements of Paekakariki and Raumati, both protected by sea walls, Queen Elizabeth Park is home to the last remaining stretch of unprotected dunes on the Kapiti Coast. Once a part of a huge system that stretched from Paekakariki to Foxton, the dunes are being dramatically eroded, particularly at the northern end, due to the large sea wall sitting adjacent to Raumati South. 


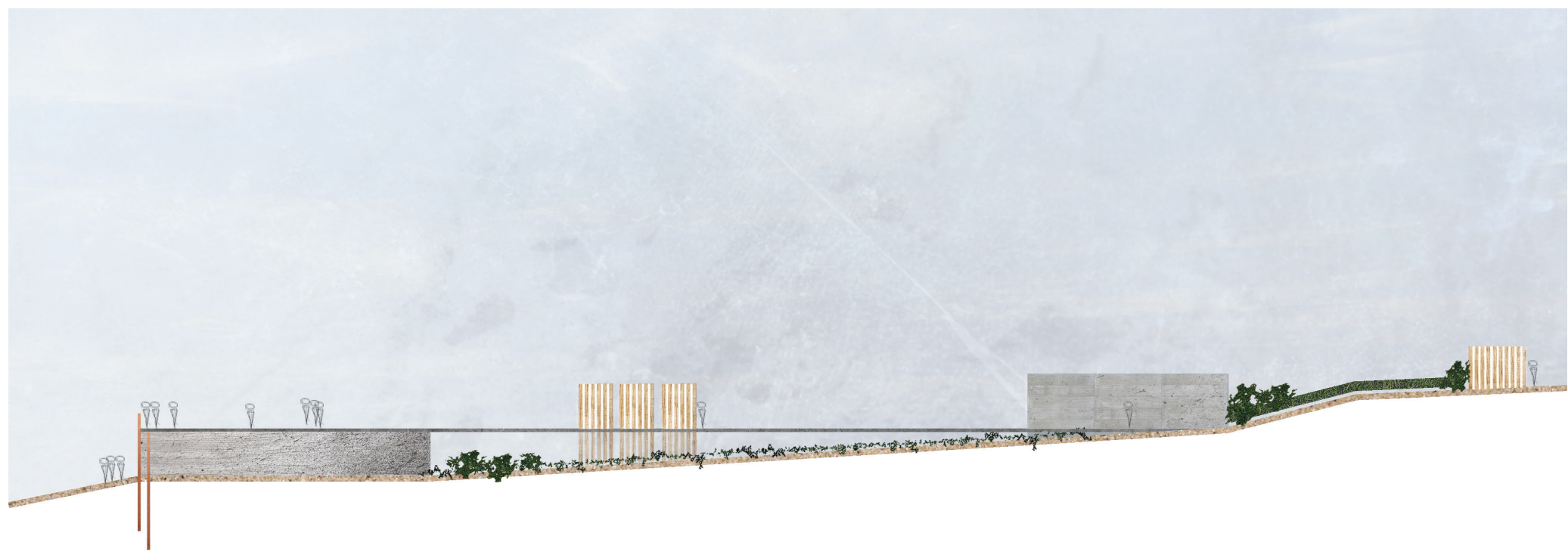

FIGURE 5

Concept section.

Section explores how a sea wall structure might be used to bring people closer to the water line. However, this approach causes a vertical divide at the coastline between the beach and the walkways above. 
The aim of this project is to propose an architectural solution that will put an end to any further extension of the Raumati sea wall. Rather than removing the wall completely, which would put the existing homes in the suburb at risk, it will propose a solution that works with the decay that is evident where the sea wall ends and meets with Queen Elizabeth Park.

This will be achieved by creating an architecture that is resilient; meaning that it is able to absorb changes in variables and still persist. The two main variables the project will face are: (1) environmental effects, (climate change and natural disasters); and (2) the way in which people inhabit the site.

The project will aim to bring people closer to the coastline and dunes and encourage them to interact with the landscape. Traditionally dune protection sees people being kept away, however this creates a disconnect between people and the environment as people tend to ignore roped off sections in favour of the shortest route to the water. By bringing people closer and immersing them in the unique environment, the project aims to create a better understanding and respect for the natural systems in the site. 


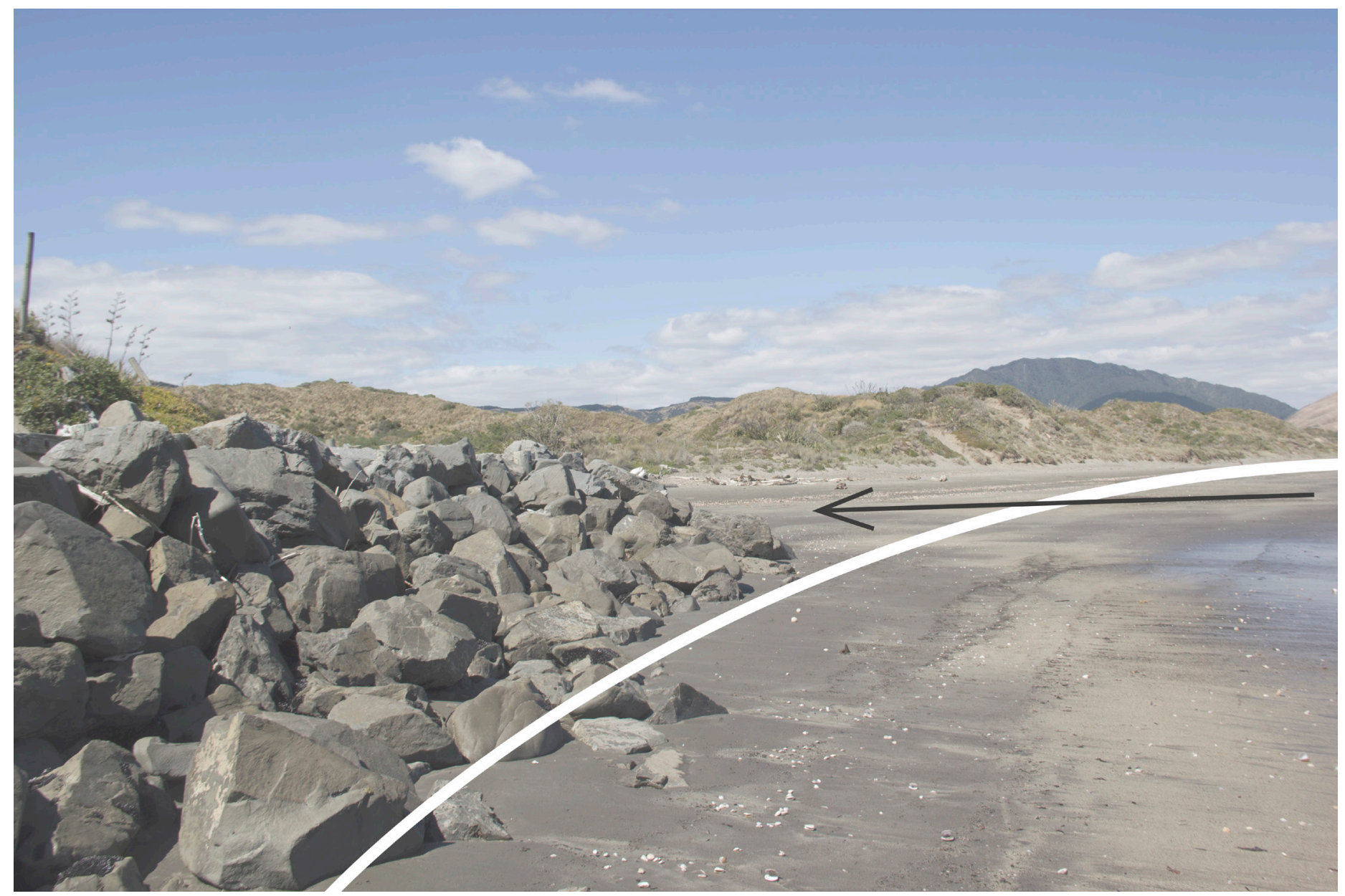

The end of the wall.

Site at northern end of Queen Elizabeth Park. In the foreground, the rock formation pictured is the end of the current Raumati sea wall. The background of the images shows where the coastline has receded. 
The scope of the project will be specific to the issues at the northern end of Queen Elizabeth Park, rather than to all sites where coastal erosion accelerated by sea walls is evident. The project will be to develop an architectural model which uses strategies of educating people and creating a resilient design to address the greater issue, of a weakened coastline due to human impact on the site. A major limitation of the project is that it is being addressed from the perspective of an architect, rather than landscape architect. This means that while there has been an attempt to understand the major issues relating to landscape architecture, the primary concern is the built form.

The focus of this project is the relationship between the built and coastal environments of Raumati and Queen Elizabeth Park. The challenge will be to create a proposal which is not only relevant to the environmental conditions and human activity currently within the site but an architectural implementation which is able to adapt and evolve as time progresses. The focus will be on resilient design which is able to absorb changes, and to create an awareness within the community, through architectural strategies, about how the way human activity impacts the coastal environment. 


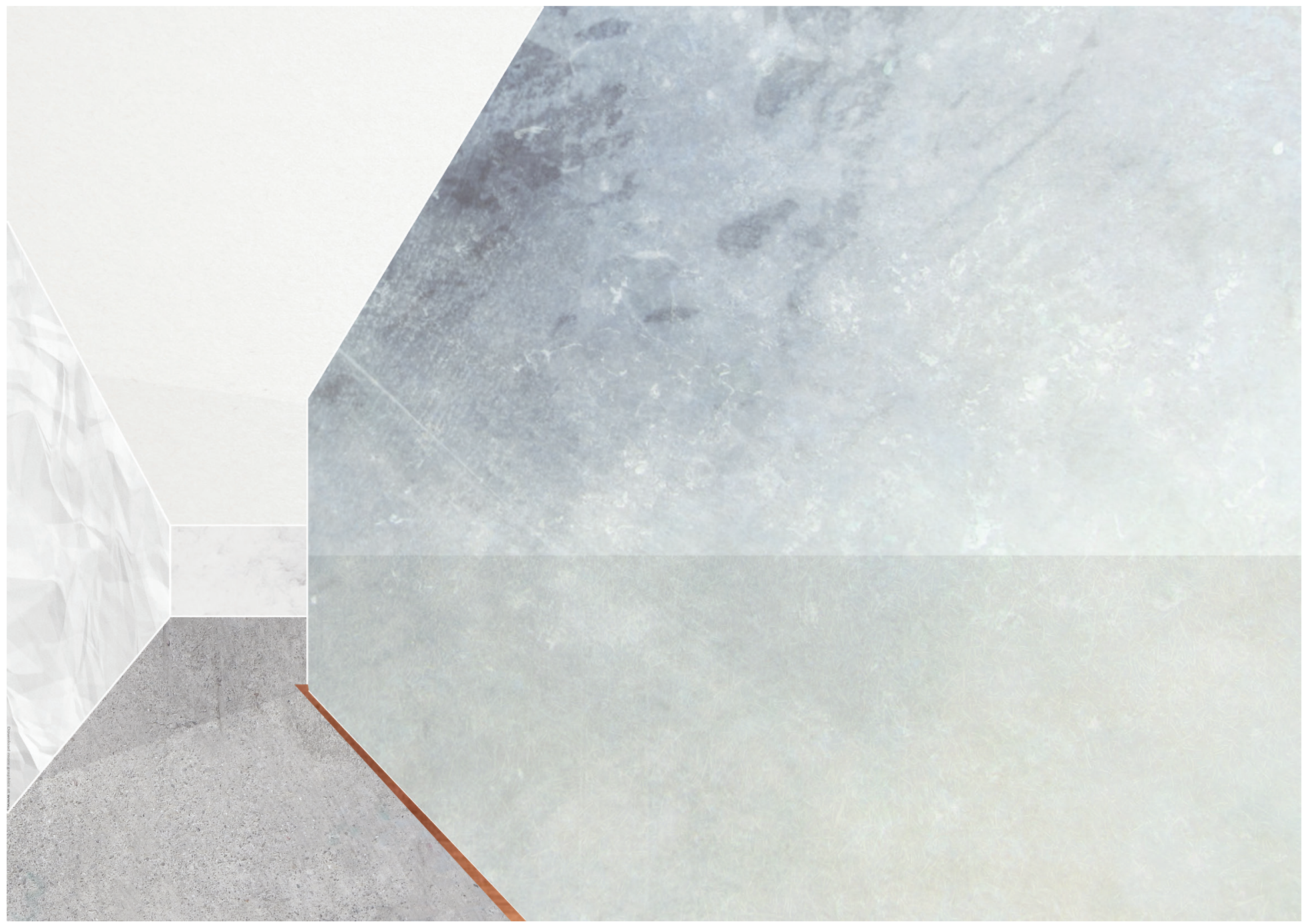

Interior/exterior

threshold.

Exploration of how glass might be used to create

an almost seamless

connection between

interior and exterior. 
The main methodology for this project will be research by design. This method sees design as a particular way of thinking or approach to knowledge, which helps to understand the broader issue. In this project the design will lead the research, rather than being the outcome of the research. ${ }^{1}$

Within this general approach, quantifiable methodologies will be used to define the site and understand its unique conditions as they will be a significant design driver. This will include using government data and GIS services to gain information regarding site, climate and coastal conditions. The methodology will also explore various scales, looking at the immediate site, and also its wider impact on the coast. This will take place alongside a highly iterative process of modelling, drawing, and mapping.

The abstract and highly textured digital drawing style will also be a key part of the methodology. This method is used throughout the design process to explore the relationships between different elements of the design, and their relationships to the site and broader context. While the images are geometrically abstract and without much construction detail, they are evocative of materials. They put an emphasis on space and material, but less on construction and tectonics.

Reflection will also be an important part of the methodology. This means reflecting on design decisions at every stage, as well as critical reflection of relevant texts and precedents.

1 Frayling, Christopher. "Provocation by Sir Christopher Frayling Part 1: Research Through Design Evolution." By Abigail Durrant and James Price, 2015. Vimeo video, 7:08. Posted Jun. 4, 2015. https://vimeo.com/129775325 


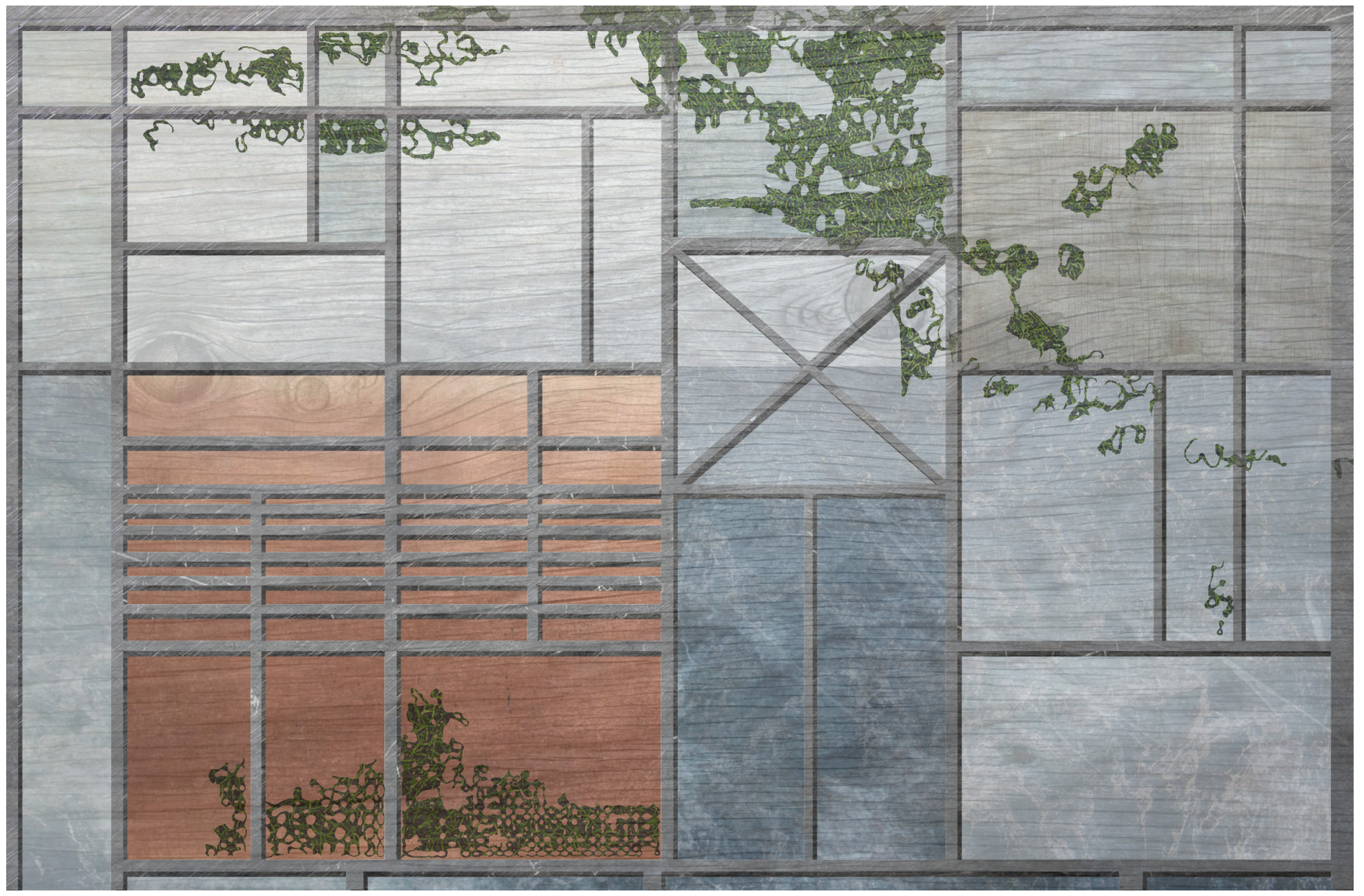

Study of a wall 1.

Explores how solid

surfaces can be broken up using shape and texture. 
How might architecture facilitate public education about the relationship between coastal inhabitation and delicate landscapes? 


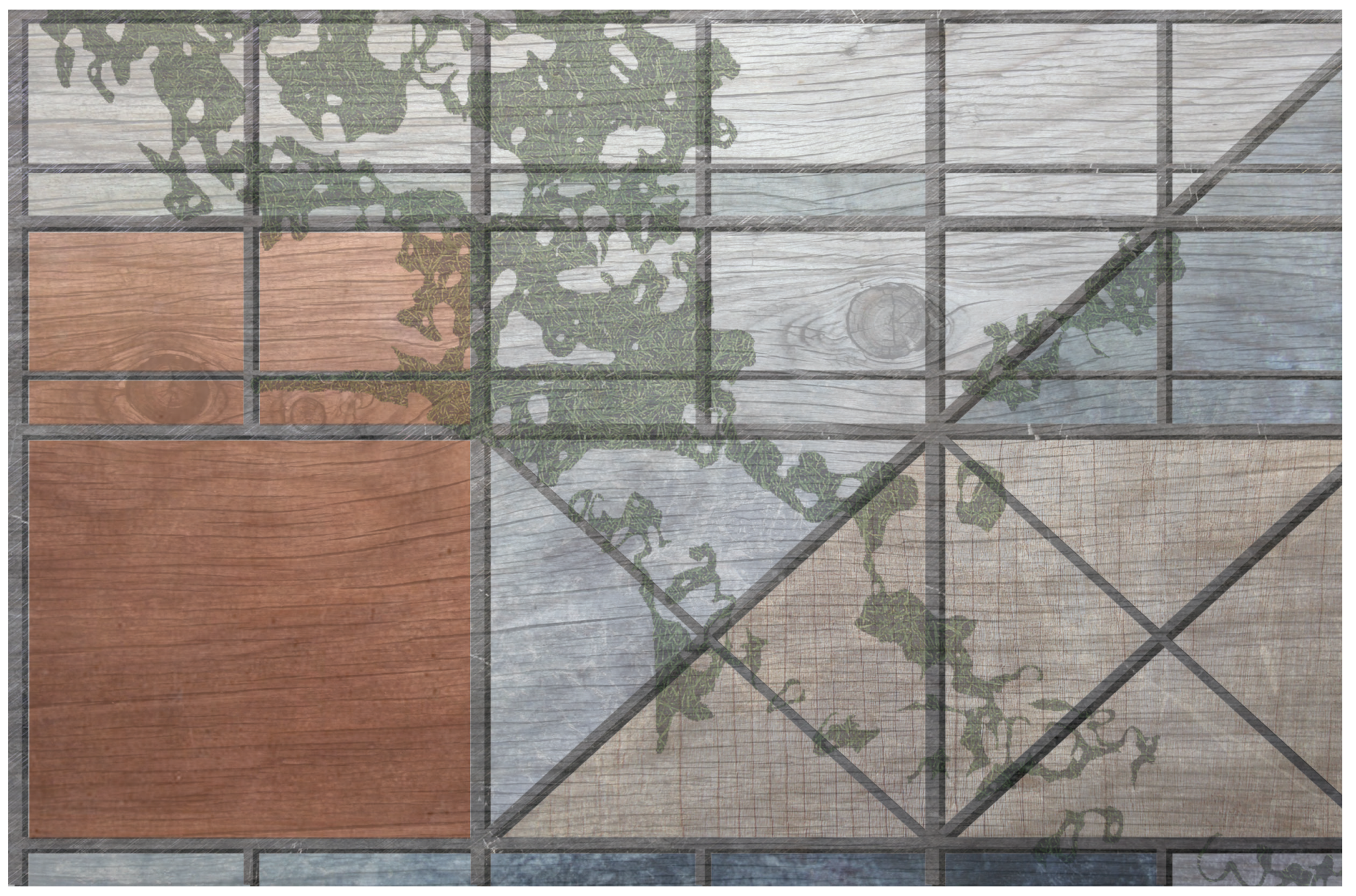

FIGURE 9

Study of a wall 2.

The repetitive patterns in this design break up the wall in a way that appears much less fragmented than the previous iteration. 

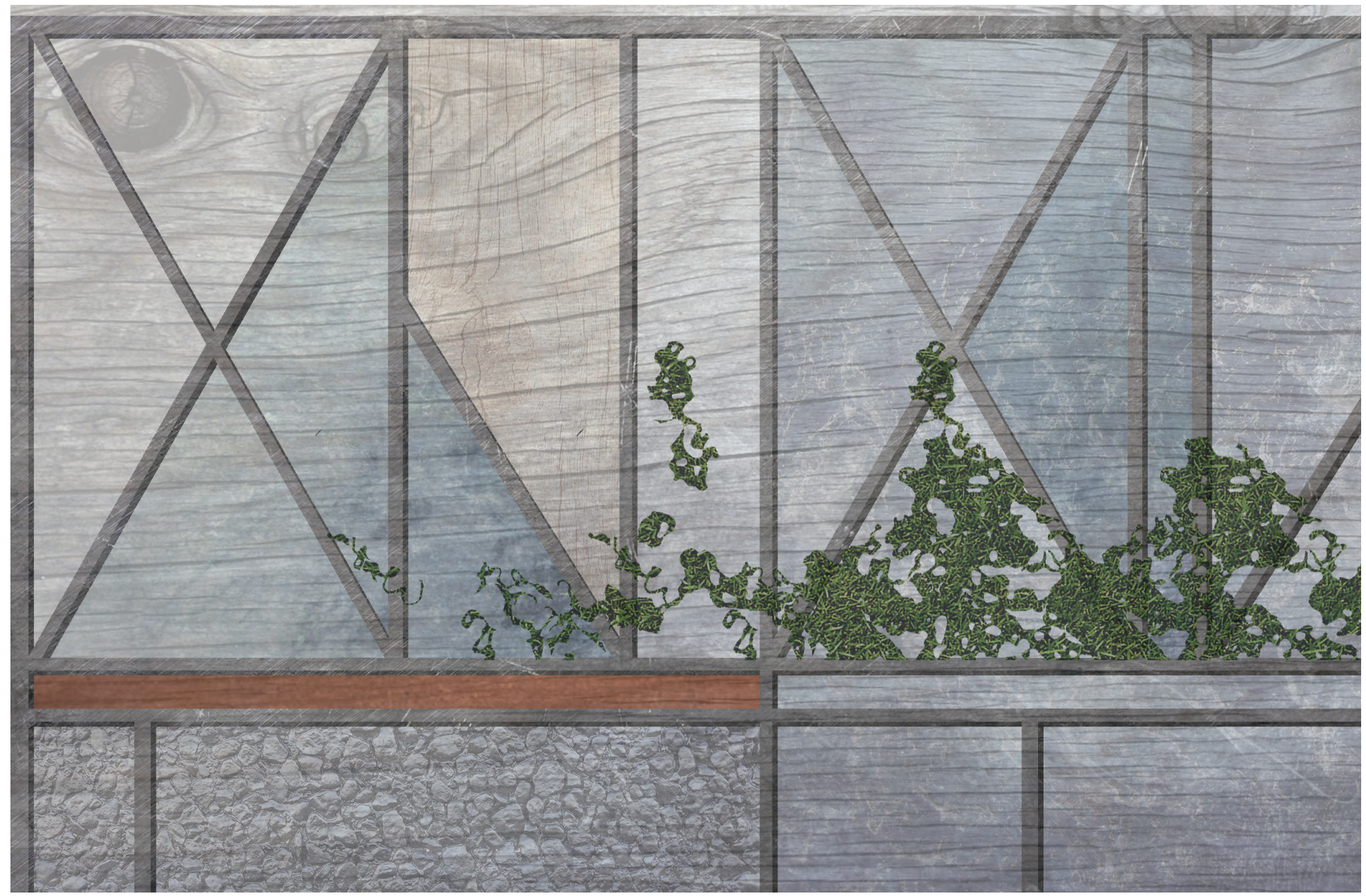

FIGURE 10

Study of a wall 3.

Using larger sections causes the wall to read as being more solid, the simplicity would also be more suitable when repeated on a large scale. 


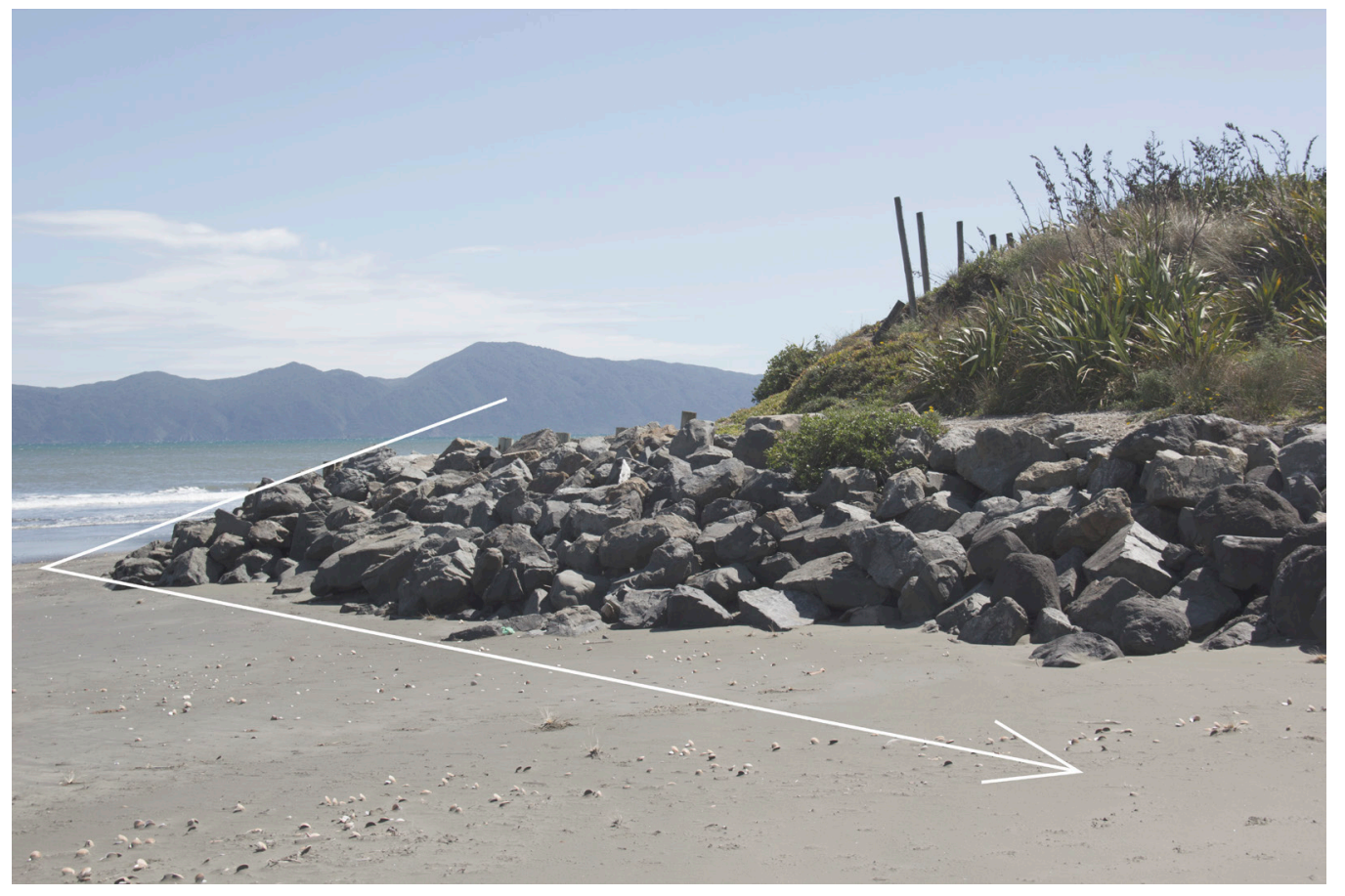

FIGURE 11

The wall.

Site photo showing rock formation and pathway at the end of the Raumati Sea wall. The rock

formation is an attempt to soften the damage where the sea wall ends, however it is still solid enough that it pushes the damage further into the park.

FIGURE 12

The decay.

Site photo showing where the dune structure has been decayed because of the sea wall disrupting natural systems. The wall pushes the power of the water further down the site, exposing this part of the site to accelerated damage. 
THE PROJECT 
FIGURE 13

Wartime training camp.

Historic image of Queen

Elizabeth Park during

its time as a US Marine

training camp. 
At the beginning of the 19th century the Kapiti Coast was occupied mostly by the Muaupoko and Ngati Apa people, with the land that now makes up Queen Elizabeth Park being a significant site of occupation. ${ }^{2}$ During this time the land was mostly covered by forest, but had waterways running through the dunes which enabled canoes to be paddled from Paekakariki to Waikanae. ${ }^{3}$ Upon the Treaty of Waitangi signing, Maori began leaving the area. Subsequently, land was cleared and wetlands drained to create more farmable land for the European settlers. ${ }^{4}$ The railways were installed in the late 1880s and villages at Paekakariki, Paraparaumu and Waikanae were established soon after. In 1908 Raumati was settled. ${ }^{5}$ In 1942 the park became home to the US Marines with the establishment of three large training camps. As their training focused on preparing for beach landing defence the coastline proved ideal. On 29th October 1943, troops withdrew from the camps and within four days the camps were vacated and destroyed. ${ }^{6}$ After this time, there were proposals that saw major development including a large holiday resort with community pools, cinemas and facilities for 40,000 people to stay in the park each night. ${ }^{7}$ It was ultimately decided that the proposals would not go ahead due to the area being a "gem of national importance". ${ }^{8}$ Queen Elizabeth Park was later established in 1953 to celebrate the Queen's Royal Visit, and transferred to Wellington District Council ownership in $1990 .^{9}$

\section{Current Usage}

Fast forward to today and Queen Elizabeth Park is still a popular place for picnics, swimming, biking and horse riding. The park is also home to the tramway museum and has camping facilities at the Paekakariki end. It remains the only stretch of natural dunes along the coast and is a wonderful escape from the city.

2 "Queen Elizabeth Park - History." Greater Wellington Regional Council. Last modified Nov. 29, 2016. http://www.gw.govt. ${ }^{5}$ Ibid. Page 13

$\mathrm{nz} /$ History-4/

${ }^{6}$ Ibid. Page 14-15

${ }^{3}$ Greater Wellington Regional Council. Queen Elizabeth Park Resource Statement. Wellington: GWRC, 2008. Doi: GW/PF- $\quad{ }^{7}$ Ibid. Page 16

G-07/292. Page 5

8 lbid. Page 17

${ }^{4}$ Ibid. Page 40 

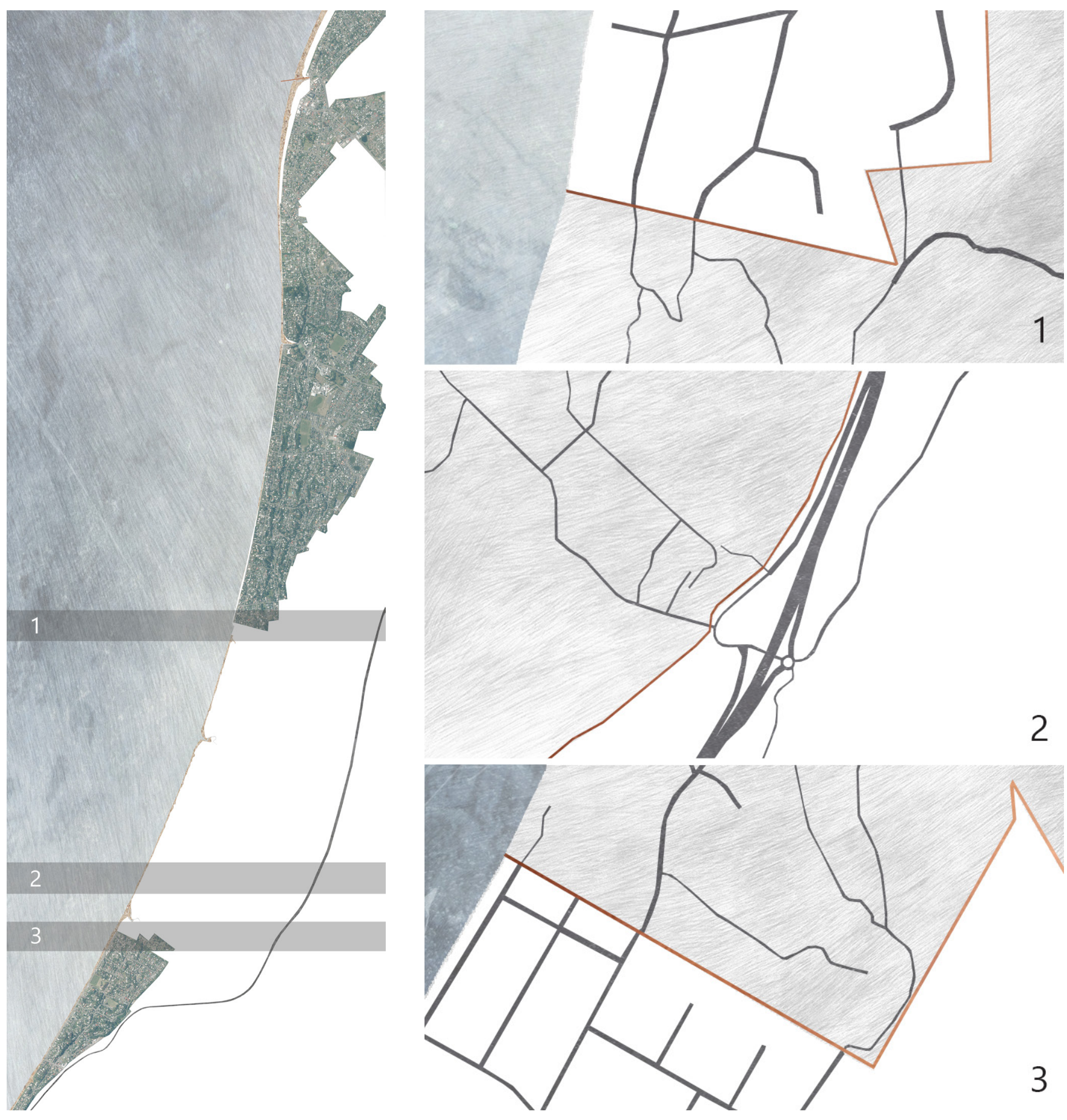

FIGURE 14

Disconnecting

communities.

The map of the Kapiti coastline shows the disconnect the park causes between Raumati and Paekakariki. The breakdowns showing each of the entry points show how multiple minor entranceway link the park to neighbouring communities. The main entry to the park is straight off SH1 via a series of confusing on and off ramps. 
A key challenge of the site is that of coastal erosion, specifically that at the northern end caused by the Raumati sea wall. Coastal erosion has been in the minds of Kapiti residents since the 2008 Shand report, which grossly overestimated the rate of decay to the area. ${ }^{10}$ This report devalued 1800 properties on the coast by using worst case scenario data and by not taking into account other data relating to accretion. ${ }^{11}$ While this has now been overturned, it is important that neighbouring properties do not feel that their own homes are being compromised by any site developments.

The area, along with the rest of the world, is also dealing with a rising sea level. While the issue may not be obviously effecting the site now, it is important that it is considered in the building design. There are also issues of increased storm surges due to climate changing which must be allowed for

People

The park also faces the challenge that it is a large open space that divides the two neighbouring suburbs of Raumati South and Paekakariki. The current main entrance comes directly off the highway into the centre of the park. Not only is this a bizarre intersection but it also means there is a lack of connection between the two communities and the park. A key challenge will be in trying to establish a better connection between the communities and park.

${ }^{10}$ Shand, Roger. Kapiti Coast Erosion Hazard Assessment. Wanganui, NZ: Coastal Systems Limited, 2008. http://www.kapiticoast.govt.nz/ contentassets/a933446e8c094de8a946d20b9f36a1de/kapiti_coast-erosion_hazard_assessment_part1_open_coast.pdf

${ }^{11}$ Blundell, Kay. "Kapiti Erosion Risk May Devalue 1800 Homes." The Dominion Post. Aug. 27, 2012. http://www.stuff.co.nz/dominion-post/news/ kapiti/7555304/Kapiti-erosion-risk-may-devalue-1800-homes 


\section{Pollution}

The pollutants recorded in Whareroa Stream by LAWA show that the water quality is considered suitable for the designated use, however its designated use is very minimal. It rates in the worst $25 \%$ of similar sites in its levels of phosphorus and ammoniacal nitrogen as well as in two tests of clarity. ${ }^{12}$ This shows that there is huge room for improvement and this will be a key challenge for the proposal to address. 
FIGURE 15

Pollution of Whareroa Stream.

Statistics sourced from Land Air Water Aotearoa show pollution and clarity levels of the

Whareroa Stream which will be redirected into the site. The levels, while acceptable, show plenty of room for improvement. 
Creating connection to land with water.

Study showing how letting water into the site rather than blocking it with a sea wall might impact the way in which visitors interact with the coastline. The concept might put the existing properties at risk, but bringing people out over the water allows them to be more aware of its actions and impact on the site by looking at it from a new perspective. 
Education \& responsibility.

One of the key strategies will be to educate people about the impact of environmental changes in the park and to place an individual sense of responsibility upon visitors. This will be achieved using a variety of different methods as a reflection of the seven different ways in which people learn (visual, aural, verbal, physical, solitary, social and logical). ${ }^{13}$ This will translate into the building design through design through exposure to designed experiences as people move through the building, and as spaces in which these learning styles can be experienced and facilitated. Creating an environment in which members of the community feel a greater connection with the landscape will also aid in the individual sense of responsibility. People are more likely to care about things that are happening in their own backyard and thus a key strategy will be in making the park feel as though it is their own backyard.

${ }^{13}$ Lepi, Katie. "The 7 Styles of Learning: Which Works For You?" Edudemic. Nov. 27, 2012. http://www.edudemic.com/styles-of-learning/ 
Resilience.

The concept of resilience is explored by Canadian ecologist, C. S. Holling. His research explores how ecosystems fluctuate and take advantage of transient periods of other systems and favourable conditions; he attributes this fluctuation to each ecological system's success in resilience and its capacity to persist. ${ }^{14}$ While his inquiry is generally looking at living organisms such as plant, insect and animal life, his position on resilience versus stability is something that can be translated to better understand resilient architecture. He defines resilience as "the persistence of relationships within a system and as a measure of the system's ability to absorb changes of variables and still persist", he contrasts this to stability being "the ability for a system to return to an equilibrium state after a temporary disturbance". ${ }^{15}$ Holling goes on to explain that using these definitions, a system can be very resilient and still fluctuate greatly or have low stability. This is where his understanding of the topic becomes relevant to that of resilience design for coastal erosion as opposed to design for environmental events such as flooding. Where flooding is generally a temporary disturbance that naturally returns to its prior state after time, the disturbance to land caused by coastal erosion does not naturally return to its original state. He understands the balance between resilience and stability as being a product of the evolutionary history of ecological systems and as a result of the range of random fluctuations they have experienced overtime. Using this logic, it is important to understand that a structure doesn't need to be permanent or stable, but rather something that is able to absorb or adjust to the changes of variables and still persist.

${ }^{14}$ Holling, C. "Resilience and Stability of Ecological Systems." Annual Review of Ecology and Systematics 4, (1973) Page 15 


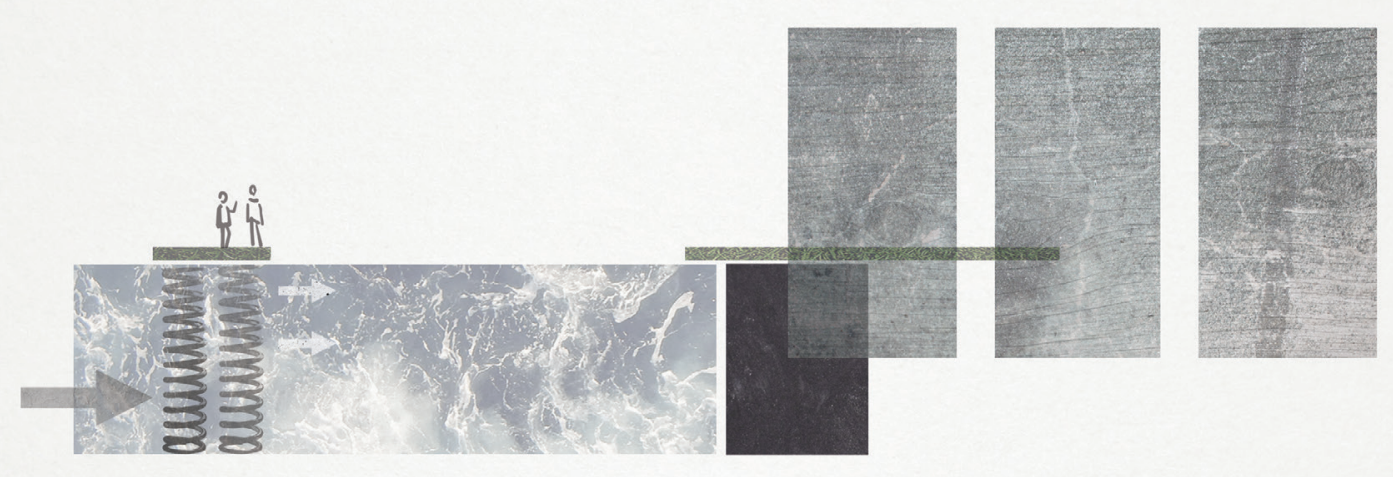

Resilience strategies.

Study showing two

approaches to resilience.

The top strategy is to

sit up above the highest

expected water levels. This

allows for fluctuation in

water levels, but means

there is a large disconnect

when levels are low.

The bottom strategy is

a vertically staggered

design which allows for

fluctuation in sea level and can be inhabited

differently as the water

levels change. 
FIGURE 18

The Retreating Village

Homes of the Retreating

Village sitting upon a

sliding system. This allows

them to sit as close to the

coastline as possible, and be pulled backward as the cliff erodes. 
The Retreating Village

Smout Allen, 2005

The Retreating Village by Smout Allen is a key precedent as it shows resilient design and managed retreat techniques.

The project lies along a rapidly decaying cliff line in Happisburgh, UK. It pays homage to the multiple homes which have been lost to the cliff by presenting each new home as a silhouette of those lost. The homes sit upon a mechanical system of pulleys and skids. ${ }^{16}$ The project is resilient in that it is able to adjust to the changes in variables as the coastline retreats and still persist, albeit in a slightly different form as the homes are pulled further back from the coastline each time. The negative to this approach is that it is only a finite solution, as the system only allows for the homes to be pulled back a certain amount before becoming redundant. 
The Dryline.

Works as a protective

system that wraps around

the bottom of Manhattan

Island. Areas of the project

are designed to adapt to

weather conditions at the

site. In this example the

flood gates sit open in

summer, partly closed in winter to provide shelter

and shut completely

during a flood to keep

water out. 
The Dryline

Bjarke Ingels Group, 2014

In contrast the dryline uses strategies of blocking to create a resilient design. The proposal is part of a larger incentive in the area that is aimed at addressing the structural and environmental vulnerabilities that Hurricane Sandy exposed in the region's communities. ${ }^{17}$ The $16 \mathrm{~km}$ long protective system wraps around the bottom of Manhattan Island. The design is resilient in that it absorbs the environmental changes that the area sees, namely flooding and increased storm surges. This approach in relation to the site in Raumati, is more successful in the way that it allows for fluctuation. The vertical levels running through the design allow for different weather severities without leaving the whole area unusable during more minor weather events. 
FIGURE 20

The Water Temple. (Left)

Explores the relationship between the visitor and

the environment by

bringing the visitor to eye level with the water level.

FIGURE 21

Church on the Water. (middle)

The large window pane enables interior and exterior spaces to become a continuation of one another.

FIGURE 22

Church of the Light. (right)

The design uses thin beams of natural light to reveal elements of the building and create 
Churches of Tadao Ando

The Water Temple, 1991

Church on the Water, 1988

Church of Light, 1999

The churches of Tadao Ando are also key to understanding and creating a new relationship between humans and the natural environment. The Water Temple explores the relationship between human and water as the visitor enters down into the building through a staircase situated in the pond, bringing them to eye level with the water. ${ }^{18}$ The Church on the Water also explores this relationship by placing the floor level at water level and the two separated by only a glass wall. In doing this Ando replaces the religious imagery usually seen in church buildings with a new representation of the Creator, nature itself..$^{19}$ Thirdly is the Church of Light, where Ando plays with and celebrates light using thin windows set back into thick walls. The building embraces the relationship between nature and architecture through the way in which light can define and create new special perceptions. ${ }^{20}$ In each of these buildings Ando is celebrated for the attention he pays to the relationship between interior and exterior spaces of his buildings. The spaces are also all successful in the way they treat the relationship between the person and the element.

18 "Water Temple." Architectuul. Accessed Nov. 20, 2016. http://architectuul.com/architecture/water-temple

19 "Church on the Water." Architectuul. Accessed Nov. 20, 2016. http://architectuul.com/architecture/church-on-the-water

${ }^{20}$ Kroll, Andrew. "A.D. Classics: Church of the Light". ArchDaily. Accessed Nov. 20, 2016. http://www.archdaily.com/101260/ad-classics-church-ofthe-light-tadao-ando 
THE DESIGN PART 1

WETLANDS 


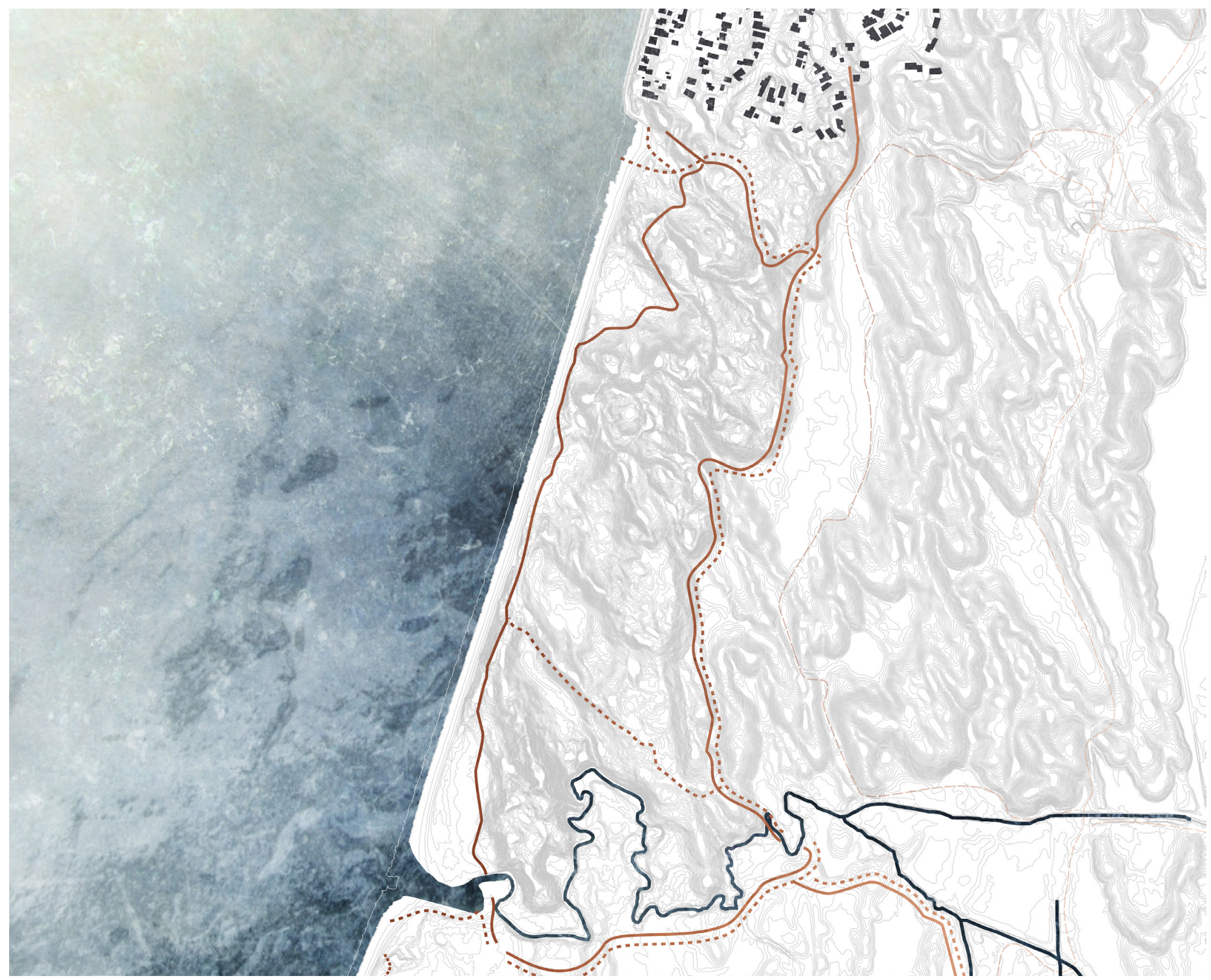

FIGURE 23

\section{Current site.}

Map details the site at present and the current system of walkways running through it. The contour lines show the large natural low in the site which sits between dune phases. 


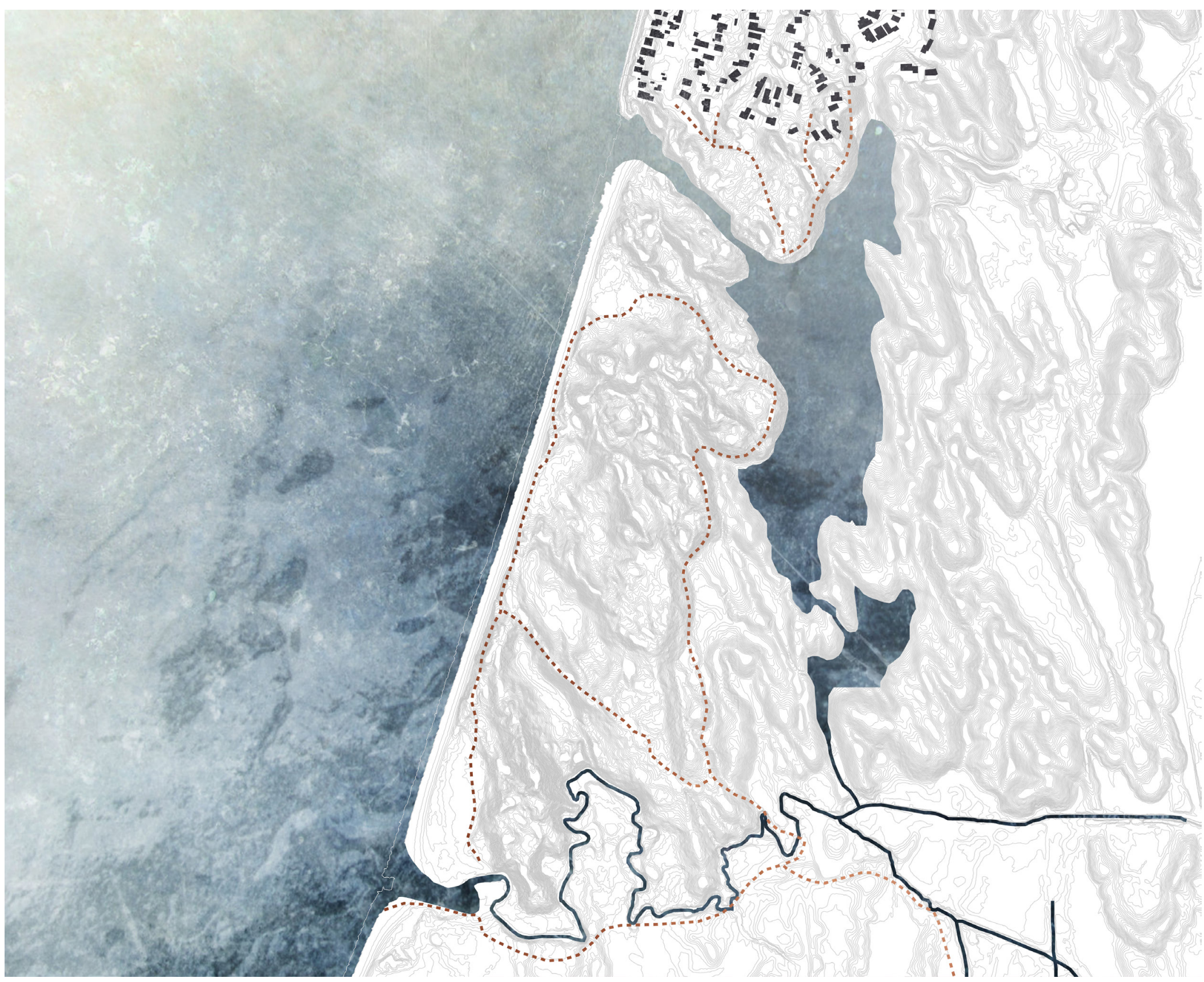

FIGURE 24

Site after wetland

reinstatement.

The reinstatement involves the re-wetting of the site,

filling the natural low area by blocking drains and redirecting the Whareroa Stream. Because of this, the walkways connecting the park to Raumati South are broken. 

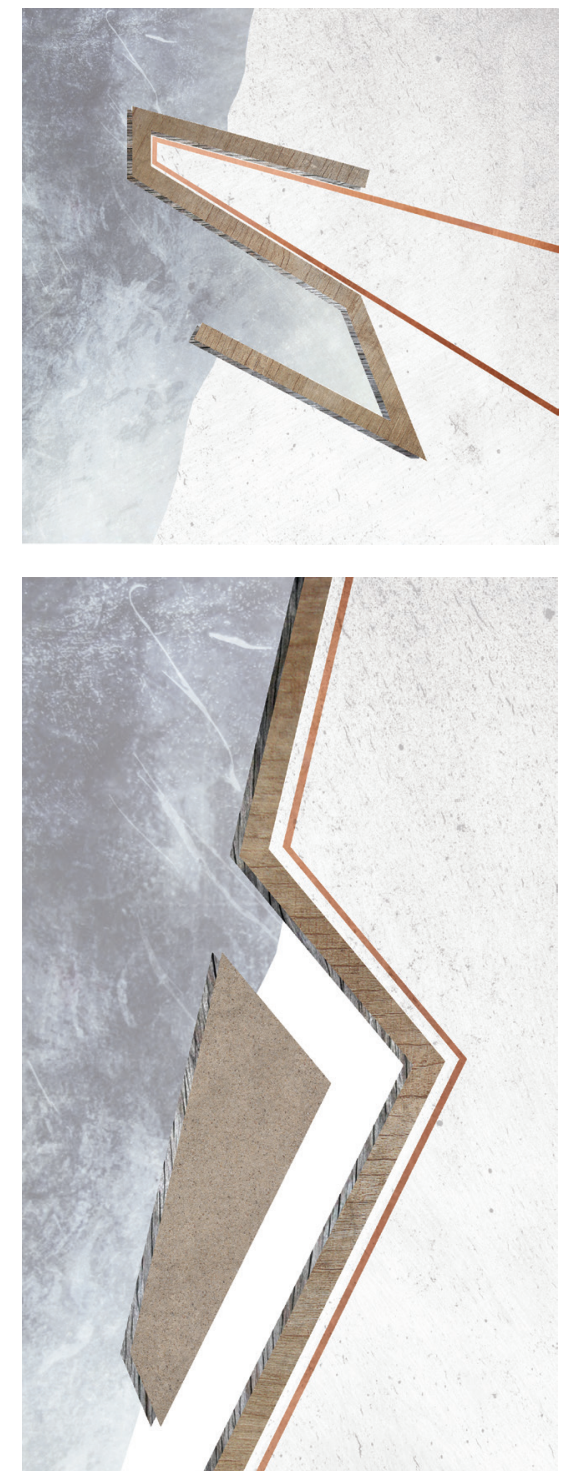
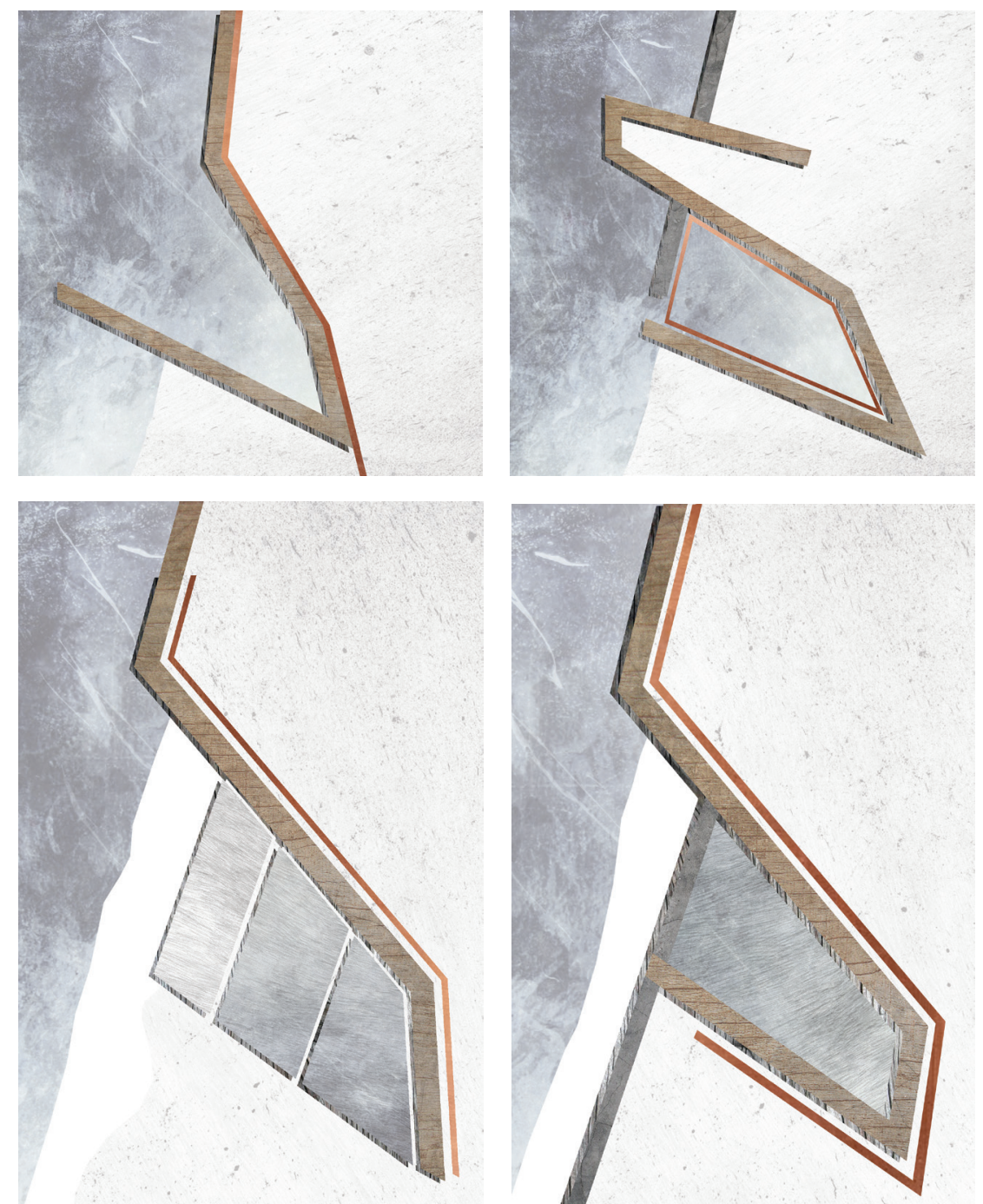

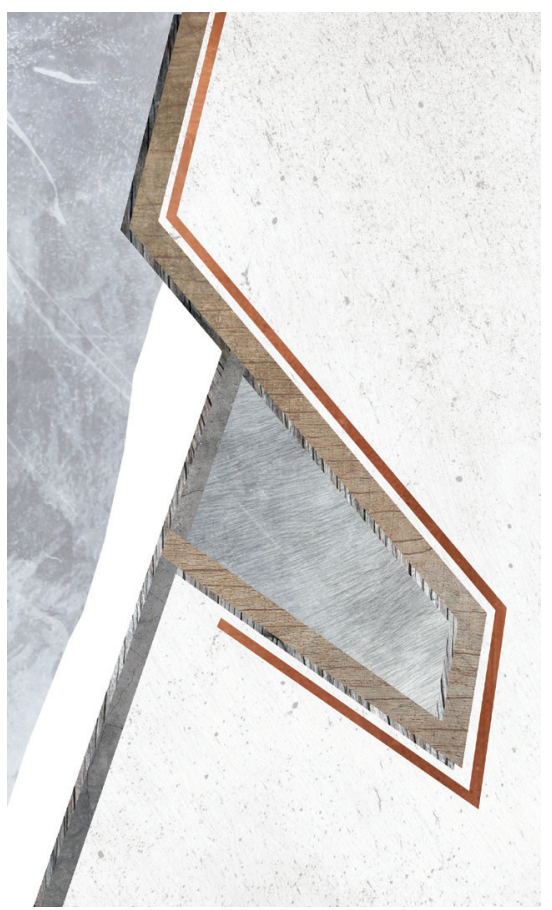

FIGURE 25

Letting the water in.

Study looking at the

second approach to

site being man made

mechanisms of letting

the water into the site.

These iterations might

create interesting spatial

qualities, but have the

potential to create even

further damage to the

natural systems of the site. 


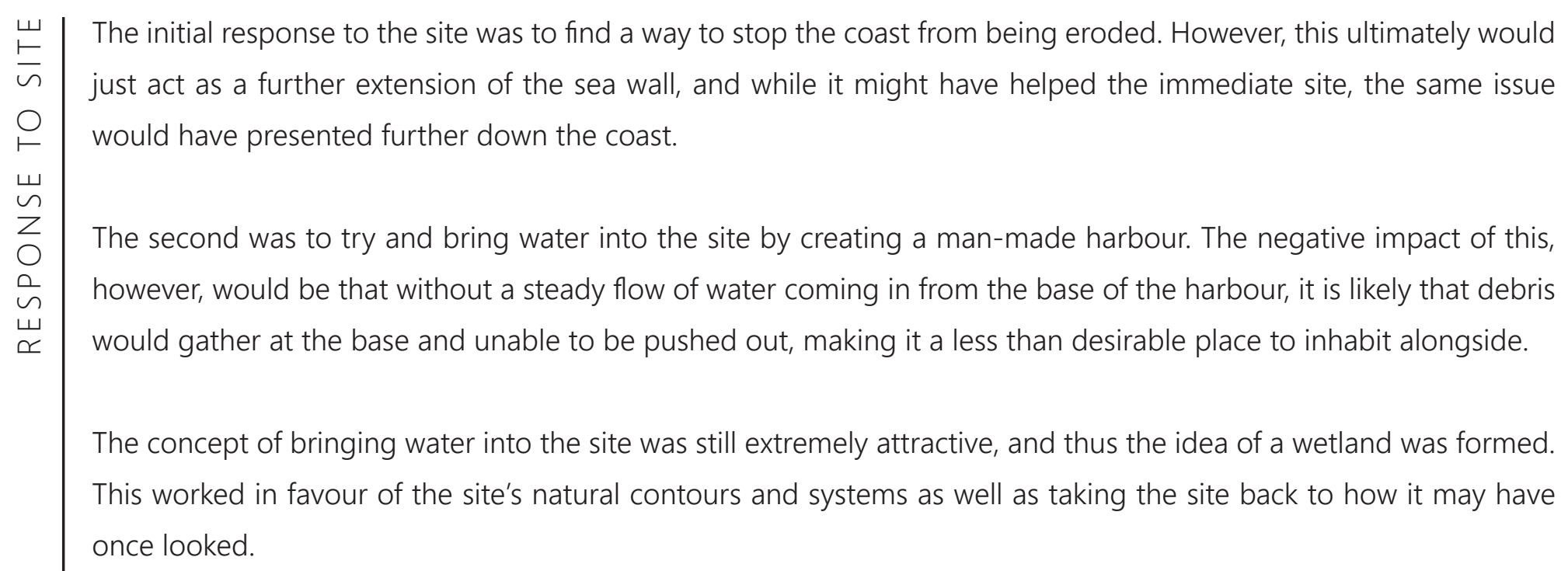




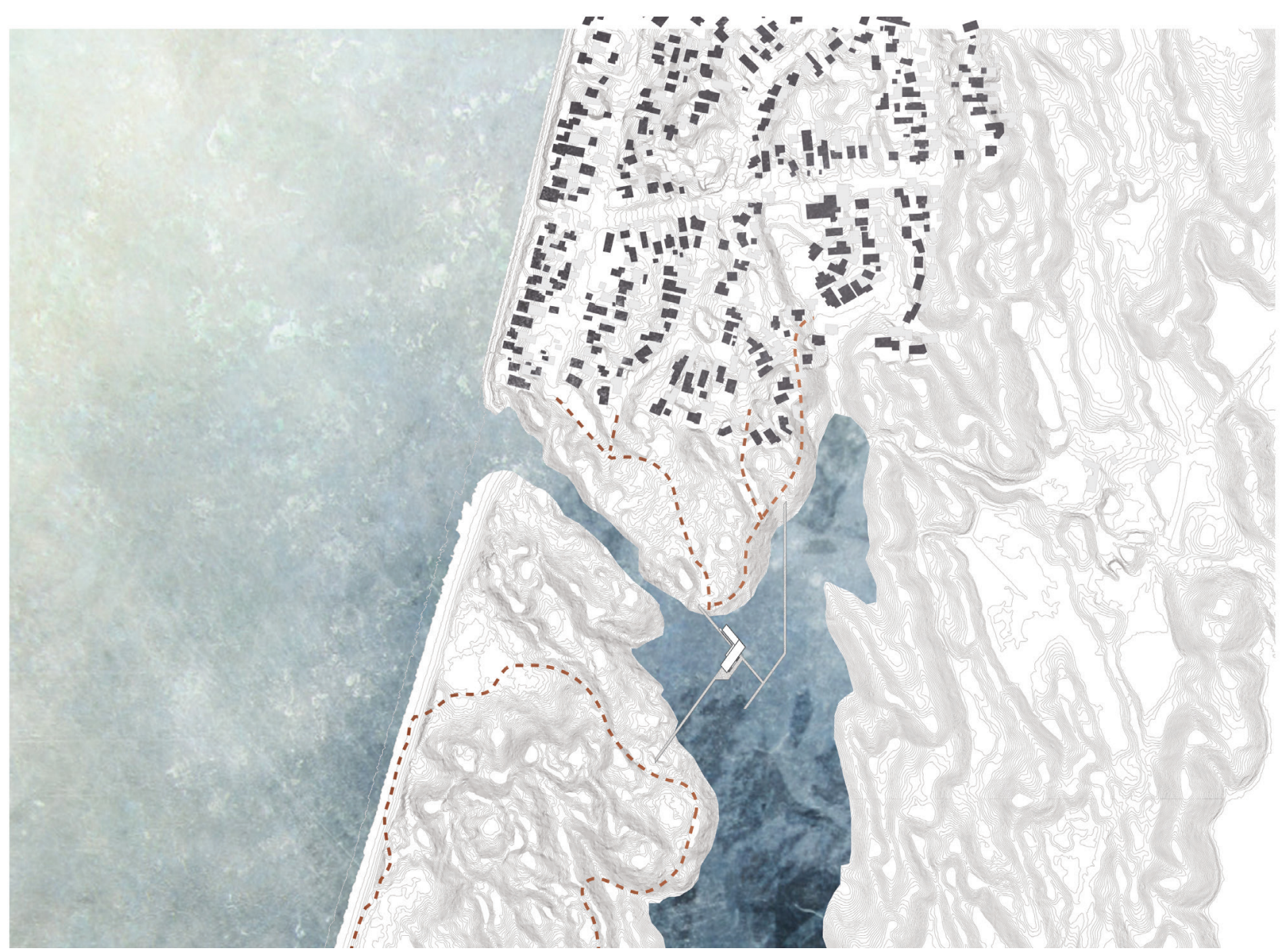

The low point.

Aerial imagery highlights the natural contours of the site and shows the natural low where the wetlands will be reestablished. 
Around 6000 years ago, the sea level was much higher than it is today, during a period known as the Climatic Optimum. As the sea level retreated, marine sands were exposed and blown to create the sand dunes. ${ }^{21}$ These have grown since then, with the coast being exposed to multiple series of dune building phases. A dune building phase is defined as the period from dune formation to its stabilisation by vegetation and soil development. ${ }^{22}$ The most recent of these phases built the Waitarere dunes which are only 160 years old and are comprised of a narrow strip of the coast, along with small patches where prior dunes have eroded. ${ }^{23}$

As the dune system increased, the drainage was compromised and the wetlands were formed. Upon European settlement, these wetlands were drained to create more land for farming, and thus a lot of native flora and fauna is now very rare and many native birds have become extinct in the region. These birds include the Little Spotted Kiwi and North Island species of Weka, Saddleback and Kokako. Habit loss is said to have been a major cause in this happening. ${ }^{24}$ There has been an attempt to reinstate some of these wetland areas in the park, however on a much smaller scale than that which would have once stood.

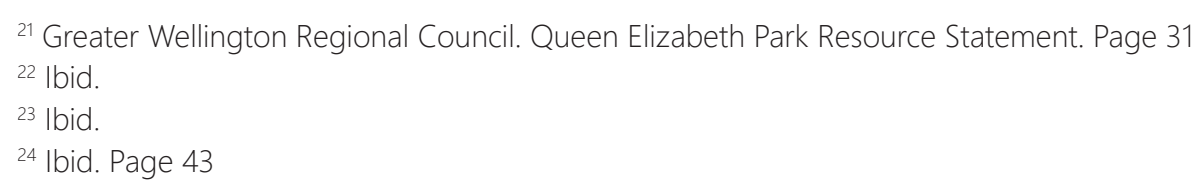


Wetland system.

Diagram showing how

wetland system removes contaminants and slows

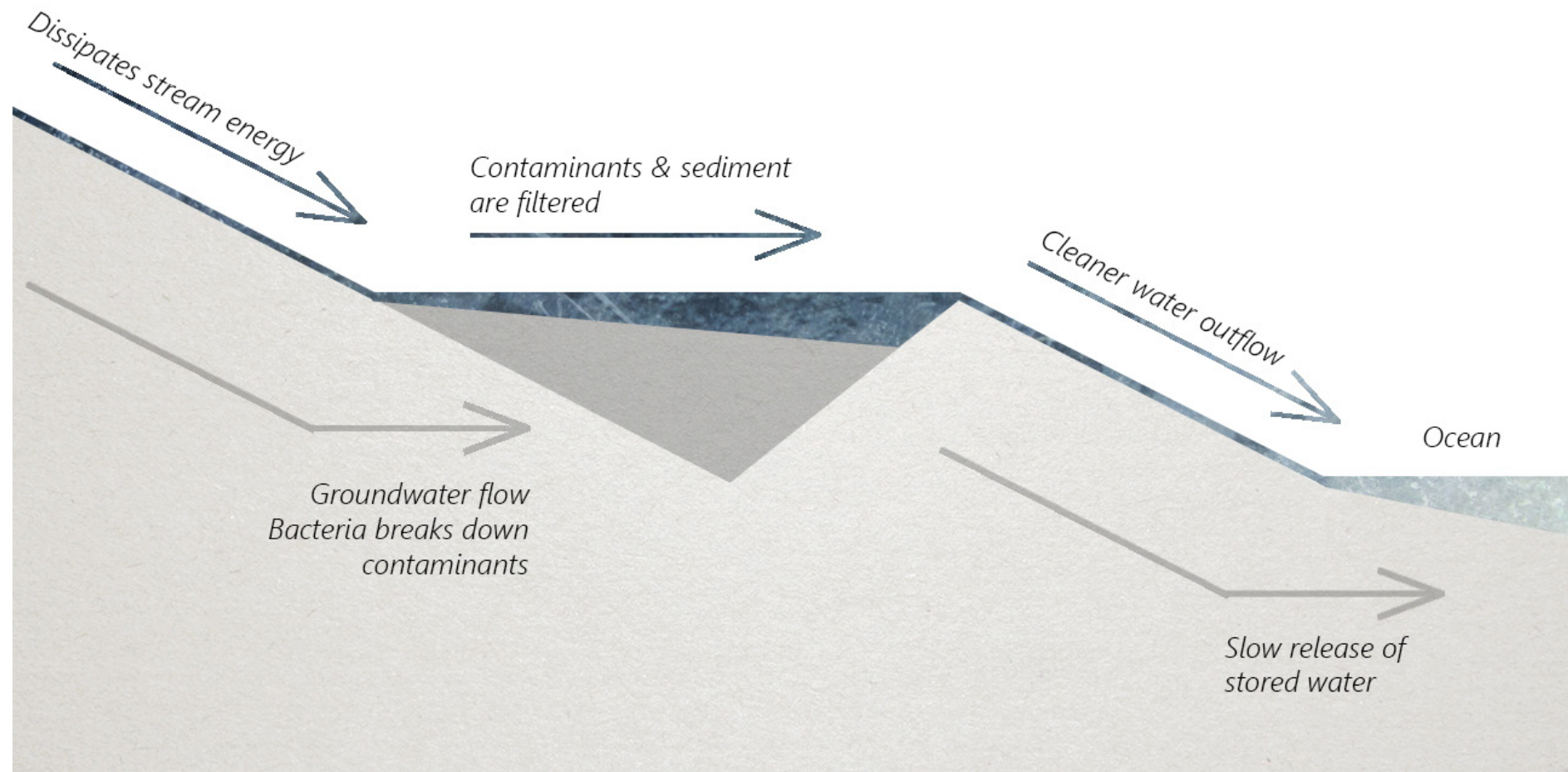


A wetland is an area of land covered in or saturated by water and supporting a natural ecosystem of plants and animals that have adapted to wet conditions. ${ }^{25}$ New Zealand has seen an $85-90 \%$ reduction in wetlands since European settlement. ${ }^{26}$ For the Maori people, they were an area of cultural and spiritual significance, providing them with food and materials for medicine, building and craft. ${ }^{27}$ Wetlands have the ability to manage climate change, with healthy peats able to absorb 2-5 tonnes of carbon per hectare each year, indefinitely locking it into their soil. ${ }^{28}$ Wetland plants are also able to slow water flow and absorb excess water during floods. This is achieved by acting as a sponge, absorbing the water during flooding and releasing it again during dry periods. ${ }^{29}$

${ }^{25}$ Greater Wellington Regional Council. Understanding the 'wet' in wetlands. Wellington, NZ: GWRC, 2005. Doi:GW/RP-G-05/35

26 "From Swamps to Wetlands." Envirohistory NZ. Dec. 6, 2009. https://envirohistorynz.com/2009/12/06/from-swamps-to-wetlands/

27 "Why Wetlands". National Wetland Trust of New Zealand. Accessed Oct. 10, 2016. http://www.wetlandtrust.org.nz/Site/Why_Wetlands.ashx

${ }^{28} \mathrm{lbid}$.

29 "From Swamps to Wetlands" 


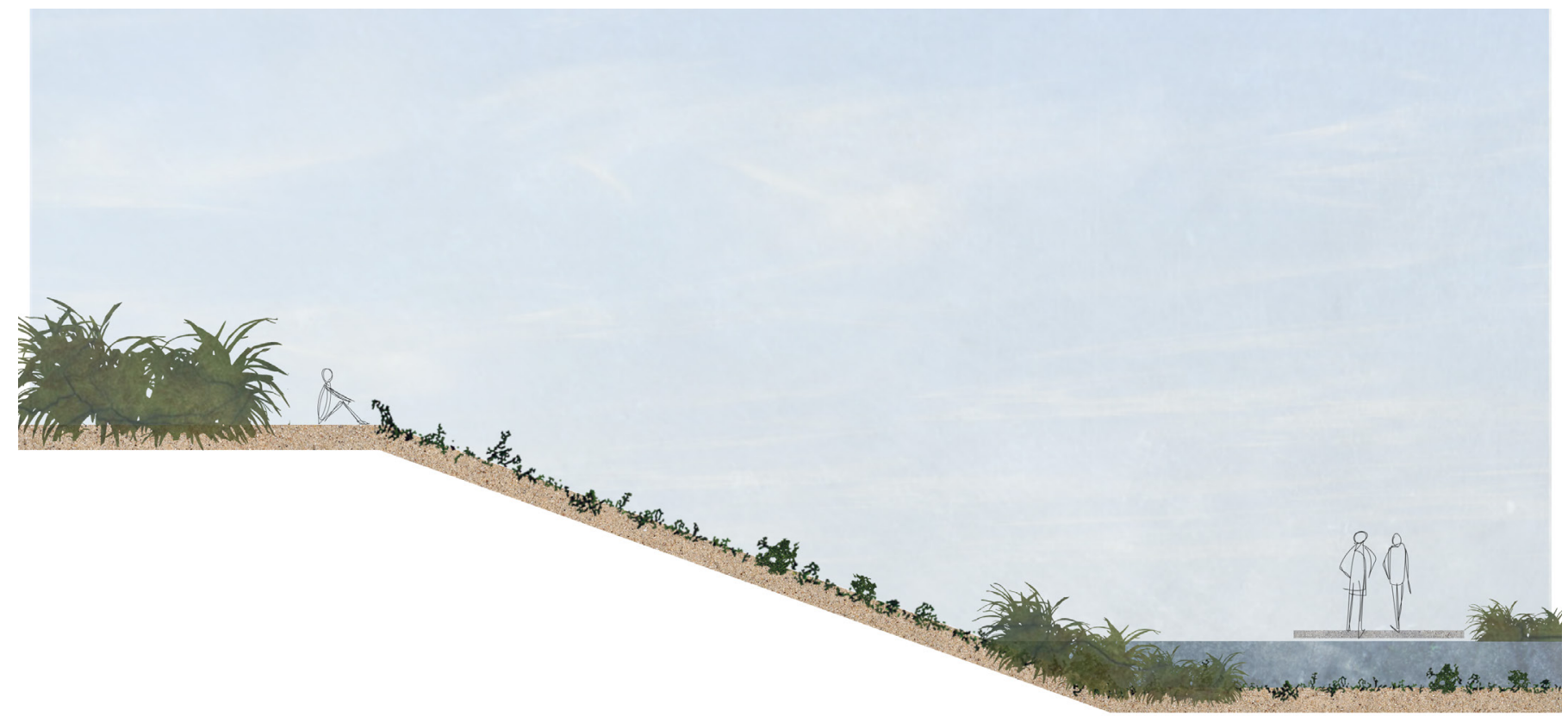

FIGURE 28

Dune to wetland in section

Reinstated wetland system sits between existing dune phases. The high dunes allow for vantage points over the wetlands, and the boardwalks facilitate a unique view of the dunes. 
The proposal sees a large area at the northern end of the park to be reinstated as a wetland zone. The new wetlands will sit between the dune phases in an area which naturally sits low in the site. The area is infrequently used at present due to it being extremely boggy during the wet seasons, and the tracks run around rather than through the area. Reinstating this area as a wetland involves blocking current drainage systems, and some human intervention to redirect the outlet of the Whareroa Stream to the site. There will also be some aid in encouraging the water flow to push through to the ocean near the current Raumati entrance to the park. This is the area which has been identified as having been extensively damaged by the sea wall. In pushing the wetland system through here, it means that any further decay caused by the sea wall will only expand the wetland system, turning the damaged site into an opportunity for improvement. 
FIGURE 29

Planting Zones.

Example by Land Care Research of how planting zones might be used to achieve water purification and control

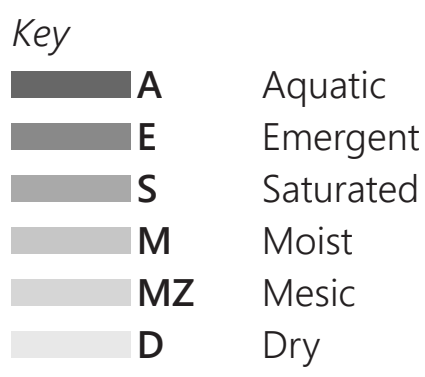


In the early 1990s an area of wetlands at MacKay's Crossing was fenced to protect it from grazing animals. As a result of this, some uncommon species of plants have been preserved. Amongst these are rare native grasses, beds of bamboo sedge, floating platelets of watermeal, buttercup and milfoil, along with several short turf plants. ${ }^{30}$ These naturally occurring plants give us a hint of what might once have lived in the wetlands and will be introduced into the new wetland system along with native flaxes which were present during Maori occupation of the site. The planting zones recommended by Land Care Research will also be considered to create the most effective planting system for water control and purification. ${ }^{31}$

${ }^{30}$ Greater Wellington Regional Council. Queen Elizabeth Park Resource Statement. Page 43

${ }^{31}$ Peters, Monica and Beverly Clarkson. "Revegetation". In Wetland Restoration: A Handbook for New Zealand Freshwater Systems. 2. Hamiltion, NZ: Print House Ltd, 2012. Doi: UDC 574(931:252.6). 
THE DESIGN PART 2

RANGER'S HUT 


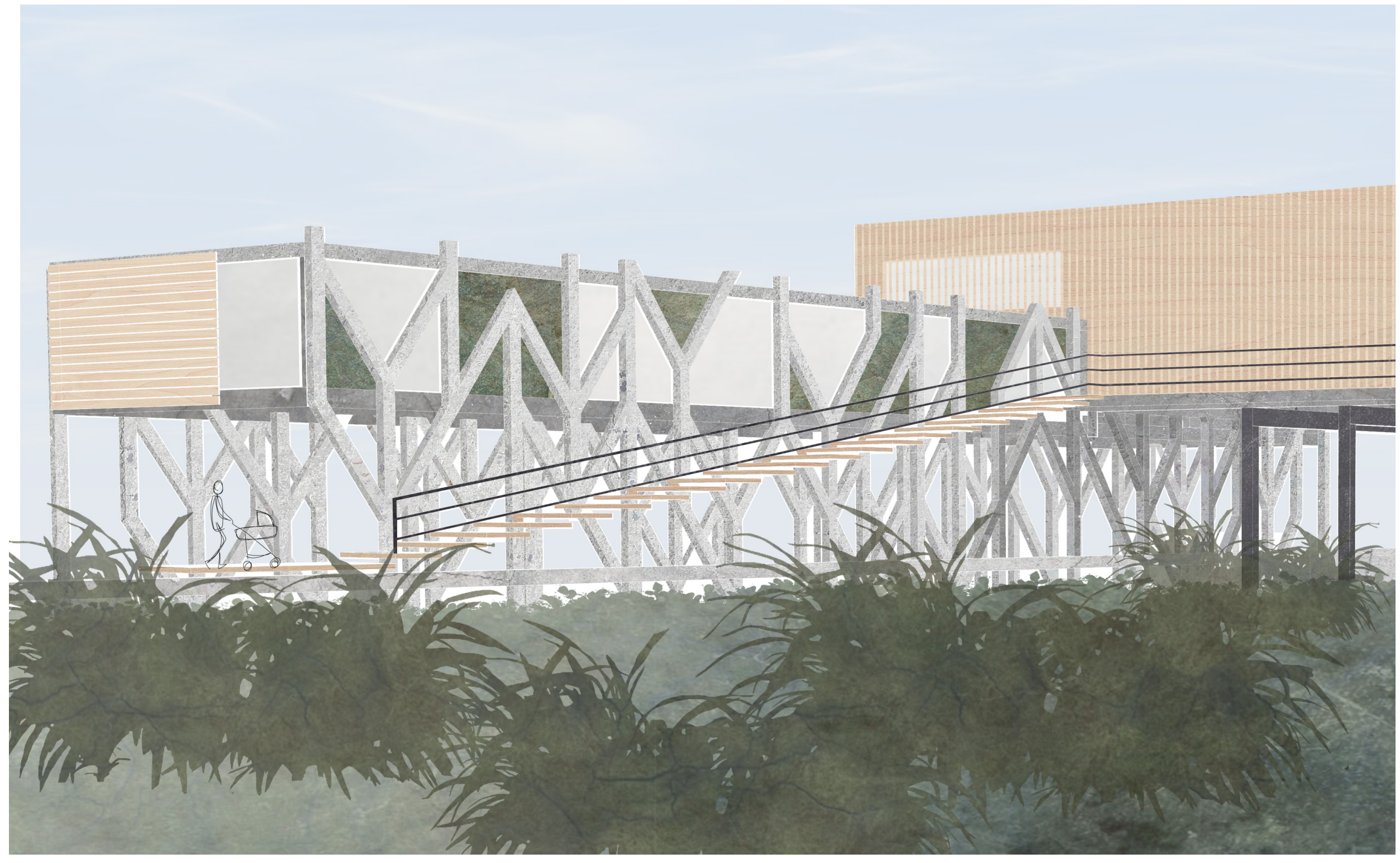




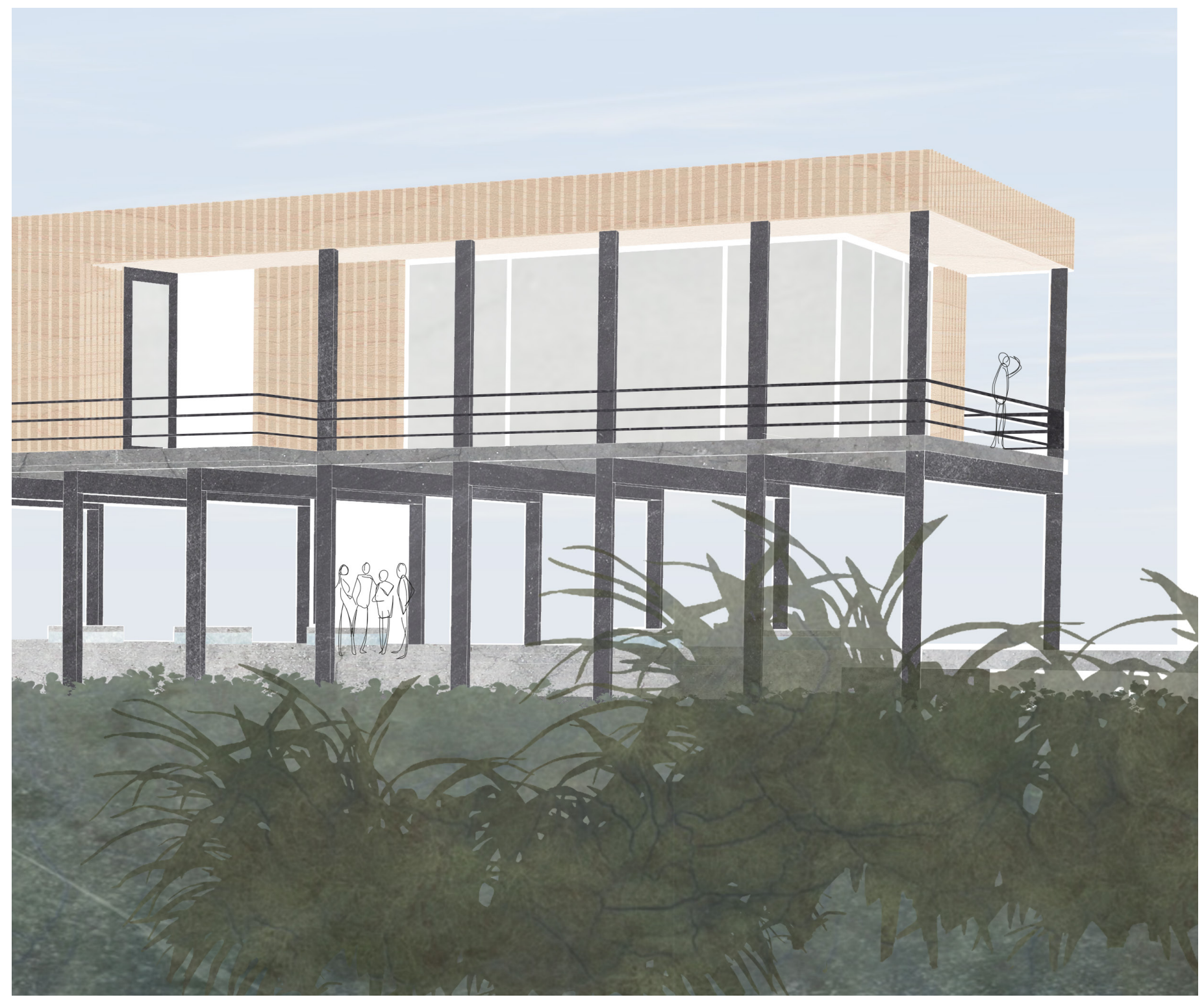

The ranger's hut.

The ranger's hut sits both above and below the

boardwalk system with an open pavilion space in the middle. 


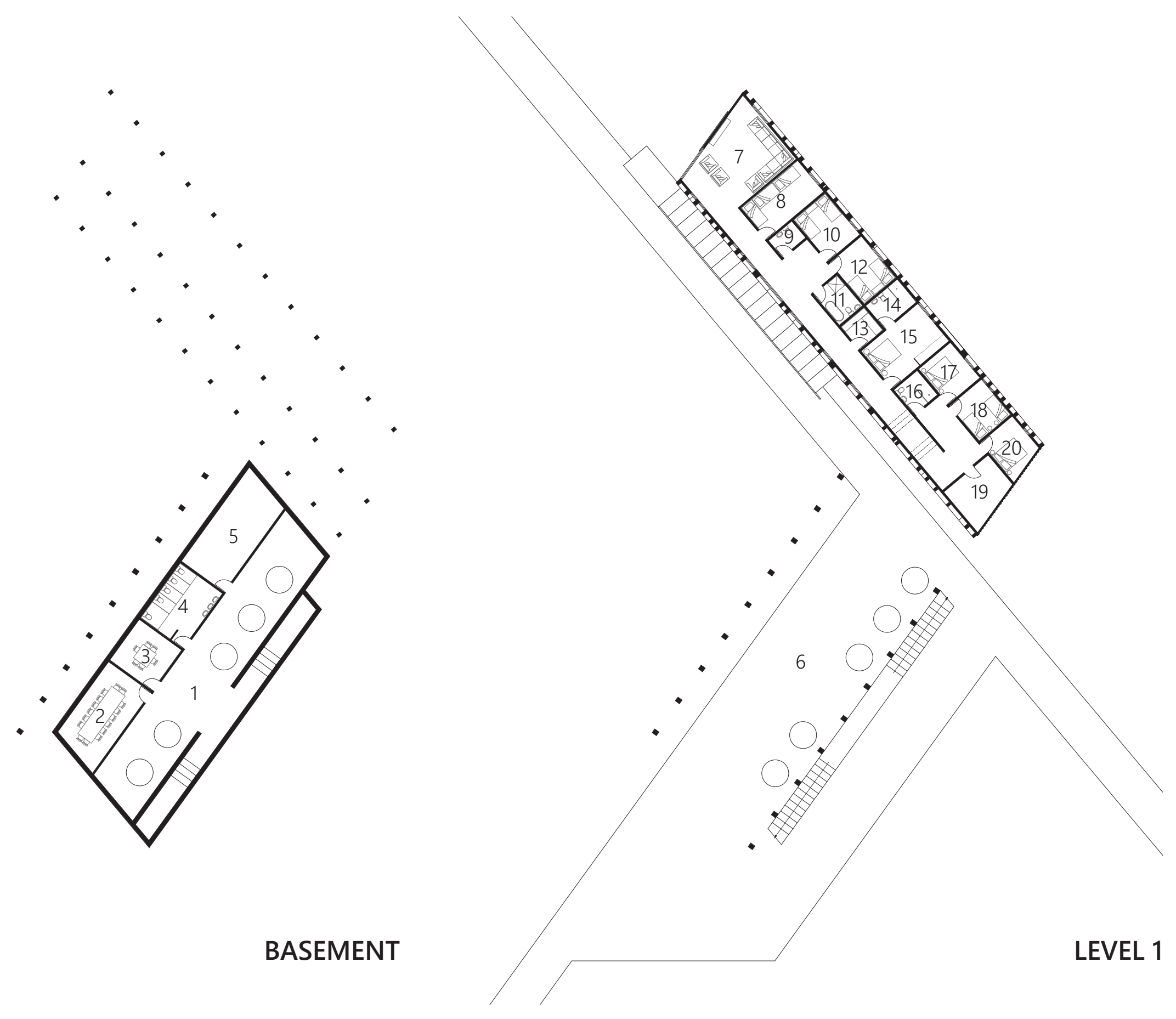




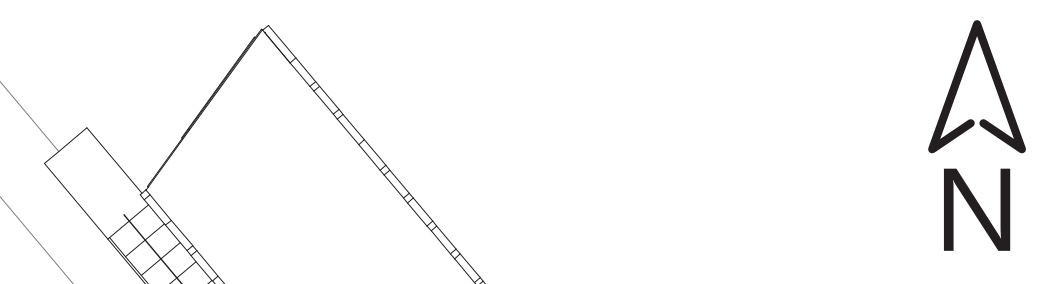

FIGURE 31

5

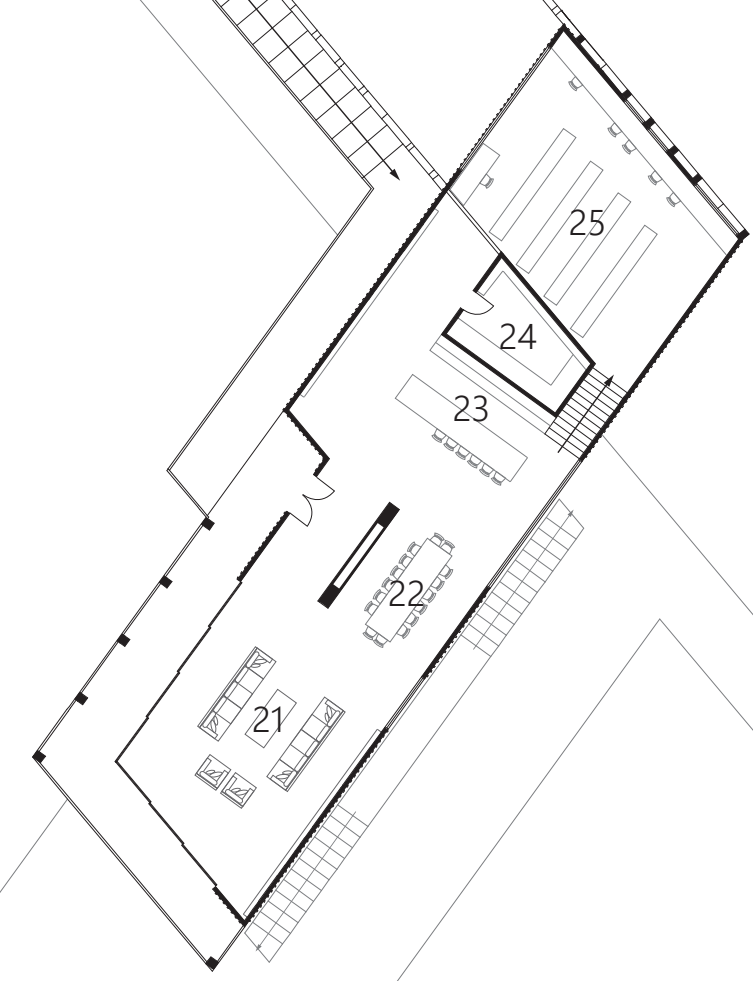

LEVEL 2

3

4

Water treatment tanks

Classroom

Meeting room

Public Toilets

Park Equipment Storage

Pavilion

Private Living Room

Children's bedroom 1

Separate Toilet

Children's bedroom 2

Bathroom

Children's bedroom 3

Laundry

Ensuite

Master Bedroom

Guest Bathroom

Guest Bedroom 1

Guest Bedroom 2

Storage

Guest Bedroom 3

Main Living Room

Dining Room

Kitchen

24 Secondary Kitchen

25 Library and Office 


\section{RANGER'S HUT AS HOME}

The word home carries many different definitions; a home being the place where one lives permanently, a social unit or an establishment providing care for people with specific needs. ${ }^{32}$ One can also feel at home; being relaxed and comfortable or in harmony with the surroundings. In describing the ranger's hut project as a home, it considers all meanings of the word and creates a space that is welcoming to anyone who enters the space, whether they live there permanently or are just coming for a short time. The feeling of arriving at a DOC hut after a long day of hiking will also be projected into the design. The overall feeling of relief, warmth and comfort, greeted by a log fire and large family whom adopt anyone who enters the building as a part of their family unit. 


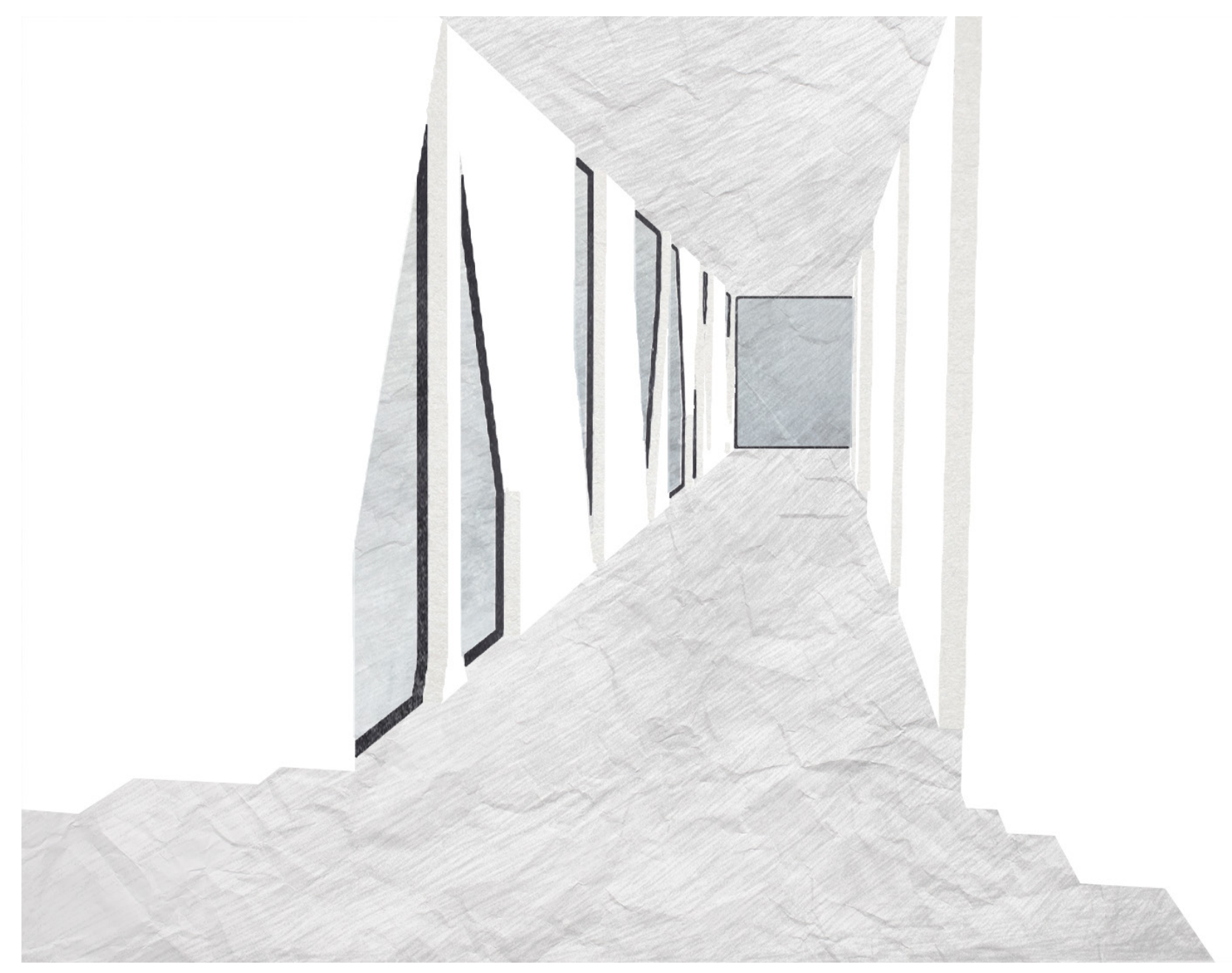

The hallway.

Long hallway running the length of the private wing of the building. Private living space sits at the end, with bedrooms sitting off to the right. 


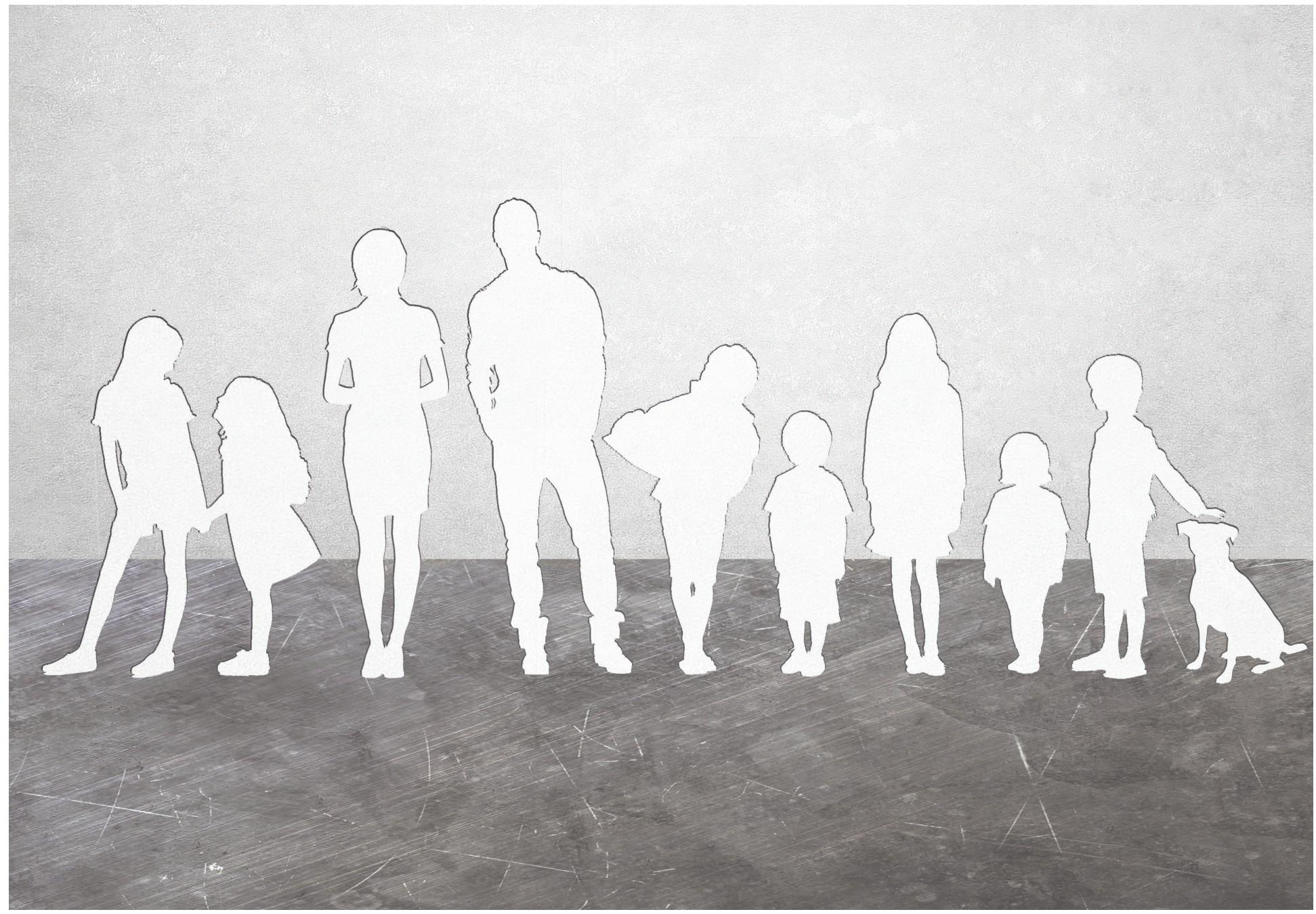

Family portrait

Image of the ranger and his family. The

large family is made up of many members with a range of unique personalities. 
The ranger lives in the 'hut' permanently with his wife, seven children and pet dog Ziggy. The family are all extremely close but within them have a very broad range of personalities and characteristics which require specific design elements.

The ranger himself is blessed with a giant personality, booming laugh and warming embrace. He inherited a large amount of family wealth when his father passed and has spent the last 10 years travelling the world; learning from other environmental centres and speakers as well as establishing relationships with people influential in environmental studies. He married his wife 17 years ago, after meeting her at a protest for women's rights. She is extremely kind and very quiet, in contrast to the large personality of the ranger. As a vegan, she spends a lot of time growing her own produce and will establish a community garden as a part of the proposal in order to teach the community about the benefits of freshly grown food. She spends her early mornings meditating while the ranger attends to park maintenance. The ranger's wife is also a trained nurse and is interested in herbal medicines as well as being able to perform first aid where necessary. They have recently returned to the Kapiti Coast where they both grew up and see it as being a great place to raise their family and share their abundance of knowledge in environmental studies they have gathered after the last few years with the community.

Their seven children are made up of four girls and three boys, the oldest being 12 and the youngest, two. Amongst them are two girls whom were adopted from Haiti after losing their parents in the 2010 earthquake. They all spend most of their time together and are home schooled by their mother. They spend as little time as possible indoors and look forward to embracing having Queen Elizabeth Park on their back doorstep, which will allow them to run, swim and kite surf as much as they desire. 
FIGURE 34
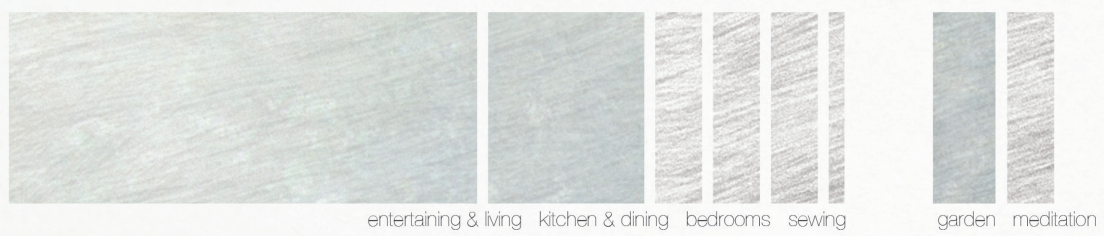

garden meditition

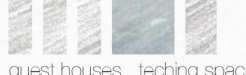

guest houses teching spaces
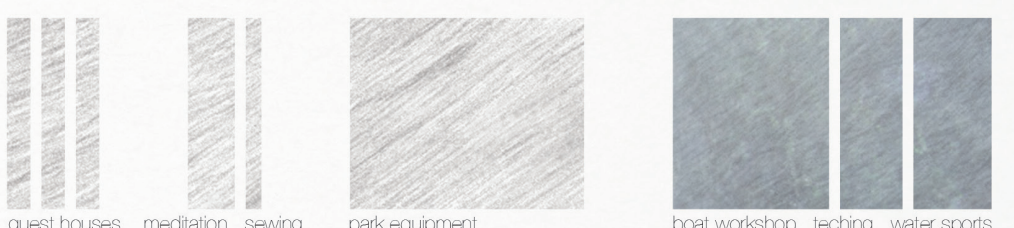

entertaining \& living kitchen \& dining garden bedrooms clascrocm
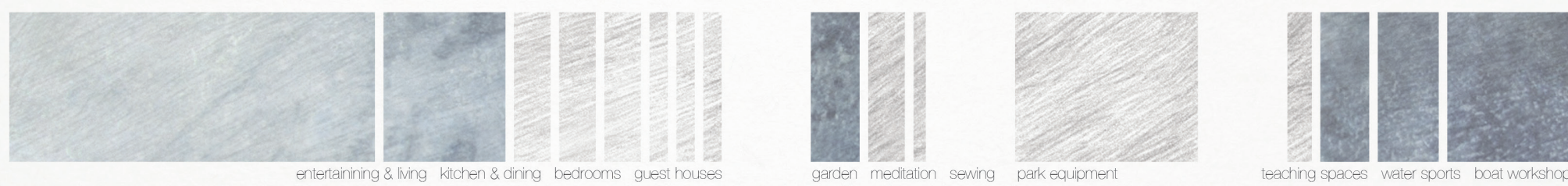

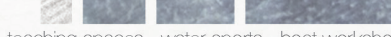
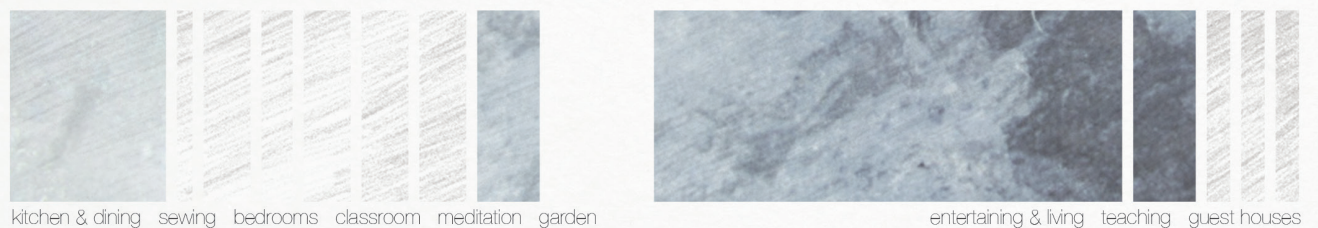

entertaning \& lling teaching guest houses
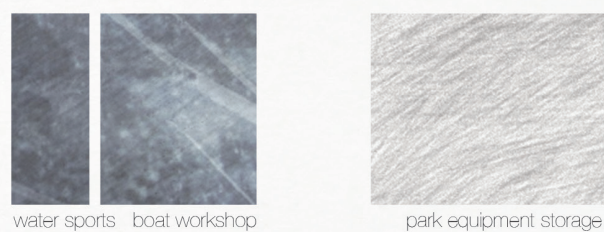

Family spatial needs.

Analysis of different needs of individual family members. Study looks at how much space each of these rooms will require and how the spaces might be grouped into public and private zones. 
FIGURE 35

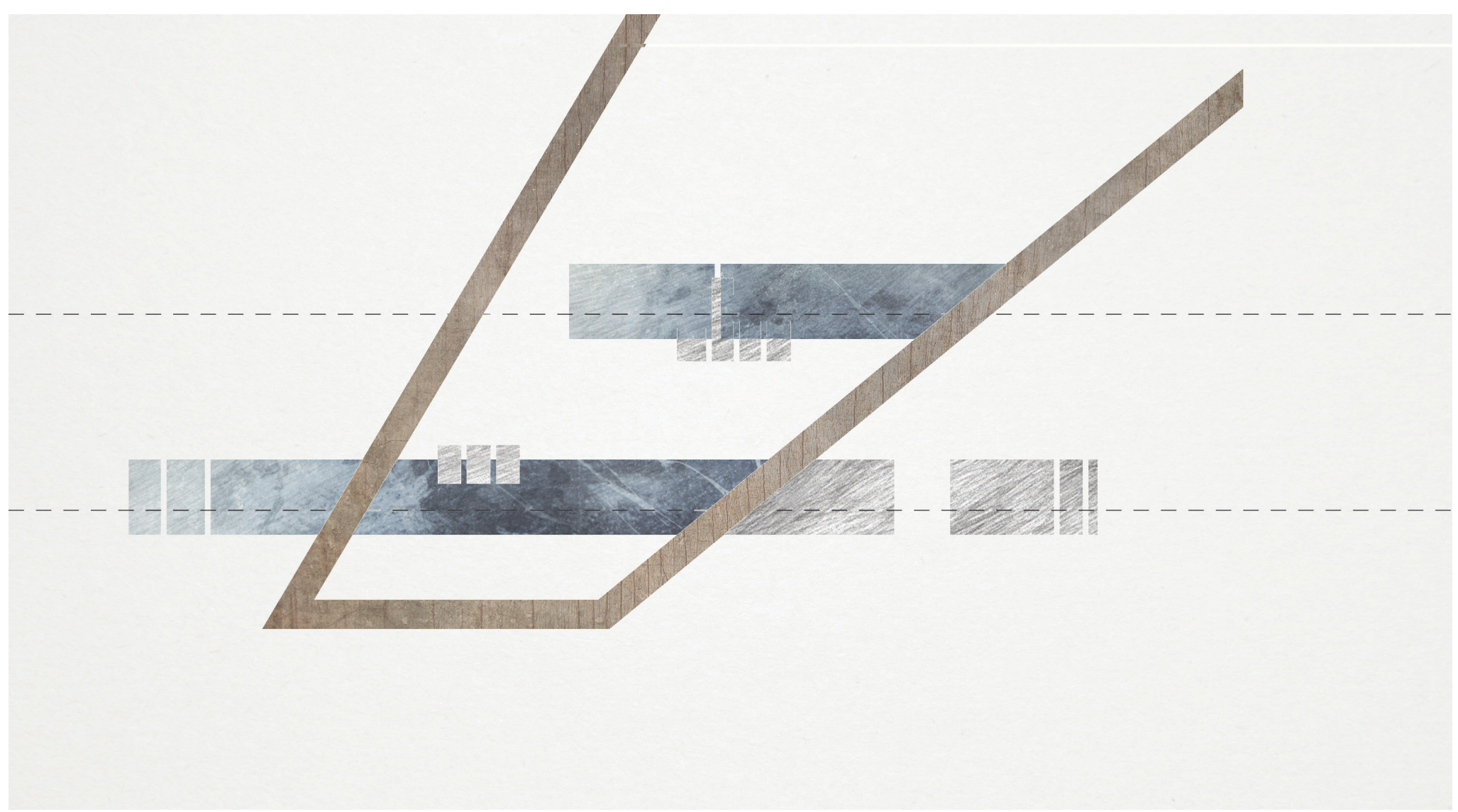

Family spaces and the boardwalks.

Study of relationship between space groupings and the boardwalk system. Looks at how running the boardwalks through the building might impact the perceptions of public space. 

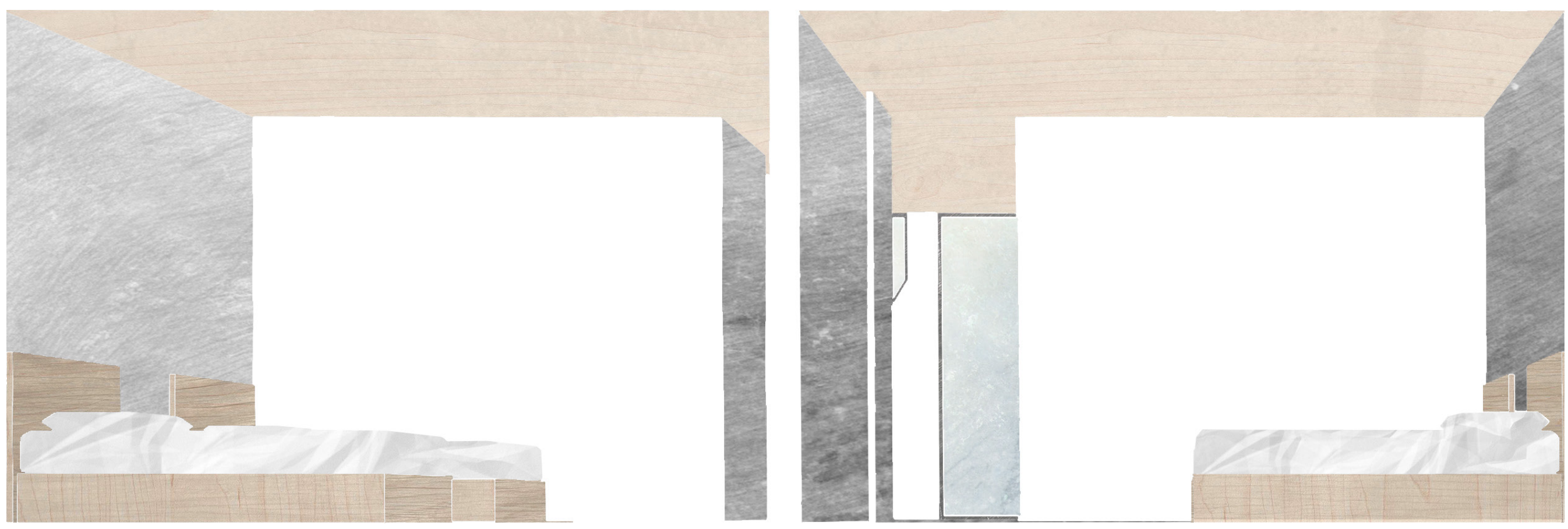
FIGURE 36

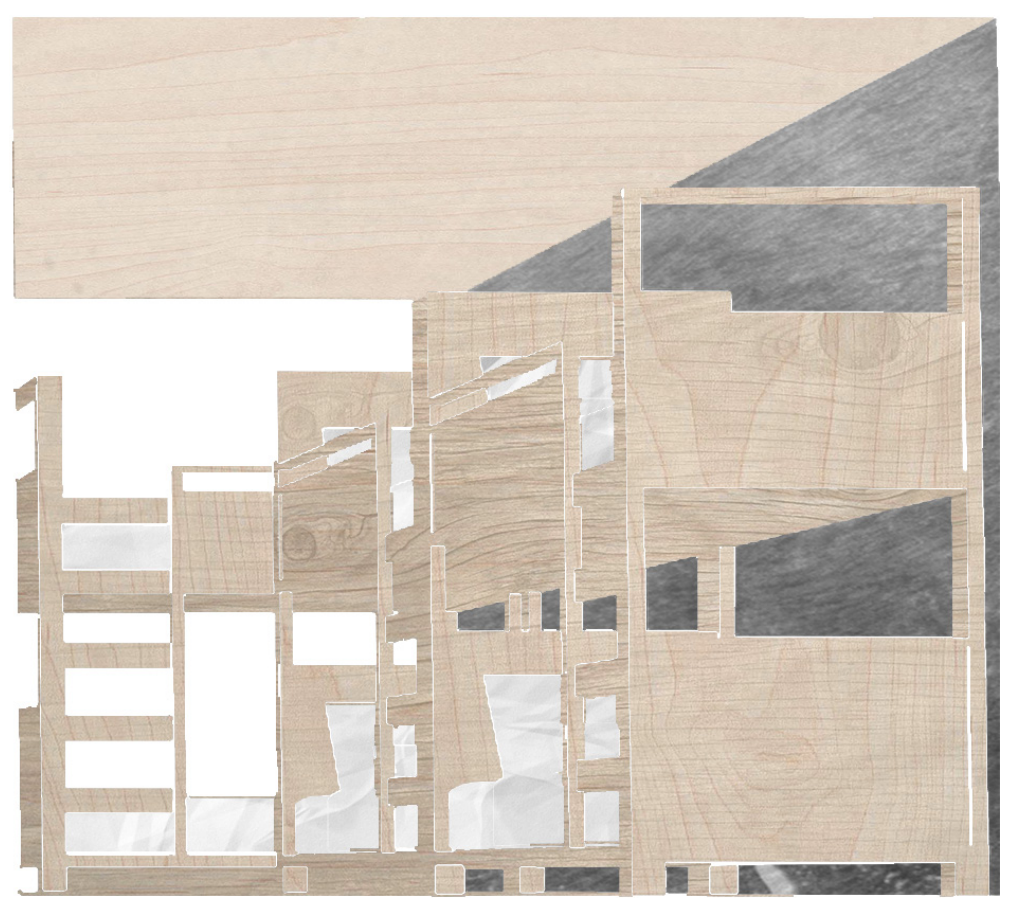

Section through children's bedrooms.

With so many children, it is vital that they

share bedrooms to save space. However, having multiple rooms allows for an increased amount of privacy for the older children. The large bunk room allows for other two rooms to be vacated if necessary to host extra guests. 


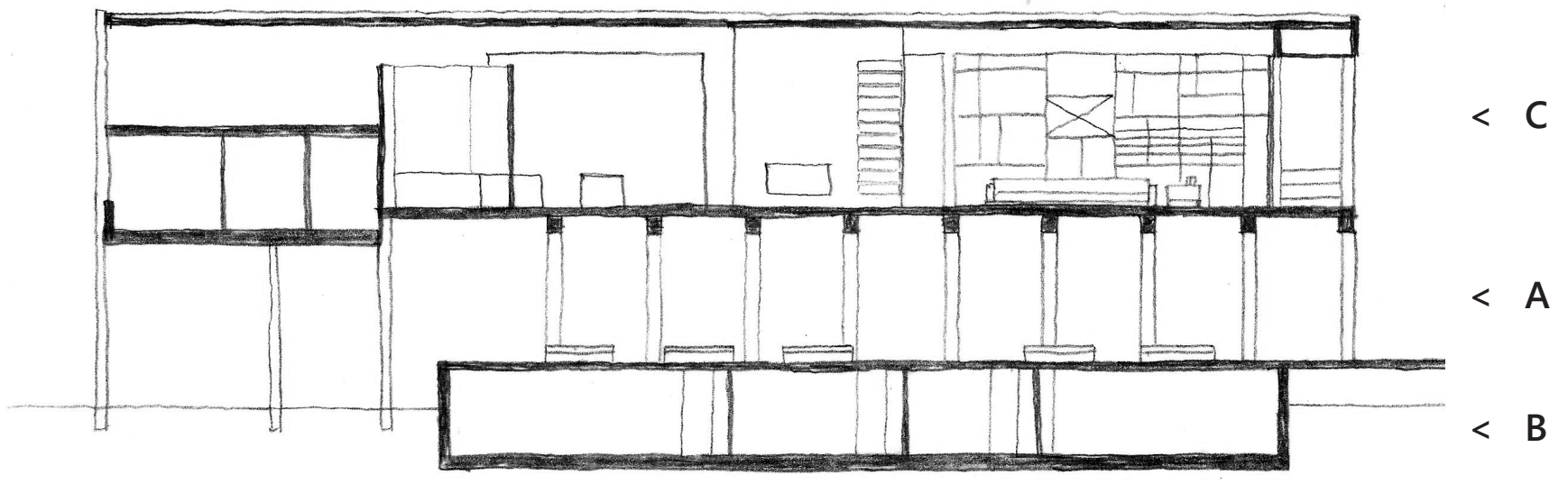

Section of the ranger's hut.

Sections running the length of each wing show how public and private spaces have been divided vertically.

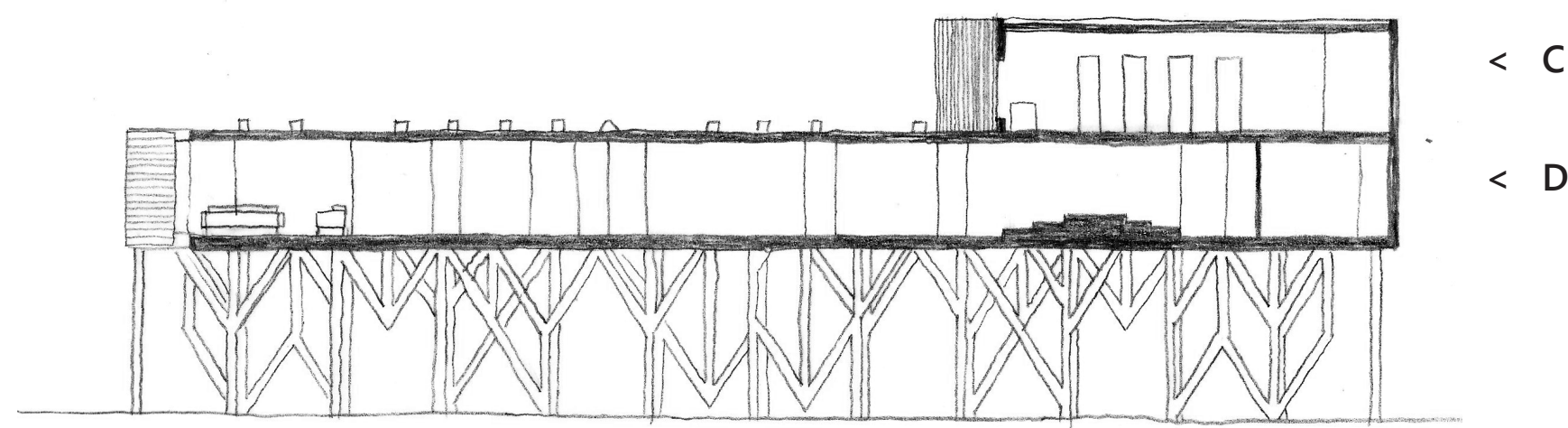


The area marked $A$ is the open pavilion space which sits between the enclosed levels. It is at the same level as the boardwalks and is the most public space. This level is mostly uninterrupted, with the exception of the columns supporting the building above and the water treatment tank lids, which act as a public seating area. The area is designed to be suitable for different activities to take place within it and will be the venue for community events as well as a space in which individuals are able to exercise, picnic or shelter from the rain.

Area B is also a public space; however, it offers a greater level of privacy for those using it. Having the water treatment tanks peeking through to the main pavilion deck encourages people to come down into the space by giving a glimpse of what is below. Sitting beneath the boardwalk, this area houses the transparent water tanks as well as public bathrooms and meeting rooms. Entry to the space will be open always, however the meeting rooms will be locked when not in use to discourage antisocial behaviour.

Area $C$ is the main living and entertaining space for the ranger and his family. It sits up above the pavilion and is accessed by a set of stairs running alongside the boardwalk system. This space is mostly private and entry will be upon the discretion of the Ranger. The home will often be opened up for people to visit with the ranger and his family hosting events and entertaining people frequently. There is also a library of the ranger's personal resources in this space which people are encouraged to use, again at the permission of the ranger. This space maintains a level of privacy in that it is still the family home will therefore be treated with the same level of respect as if it were on the roadside.

The final area $D$ is the most private space and the public are not encouraged to enter this part of the building. This area houses the family's bedrooms, bathrooms, guest quarters and has a separate private living space for the children to retreat to when their parents are entertaining. A sliding door discourages people from entering this part of the home. 

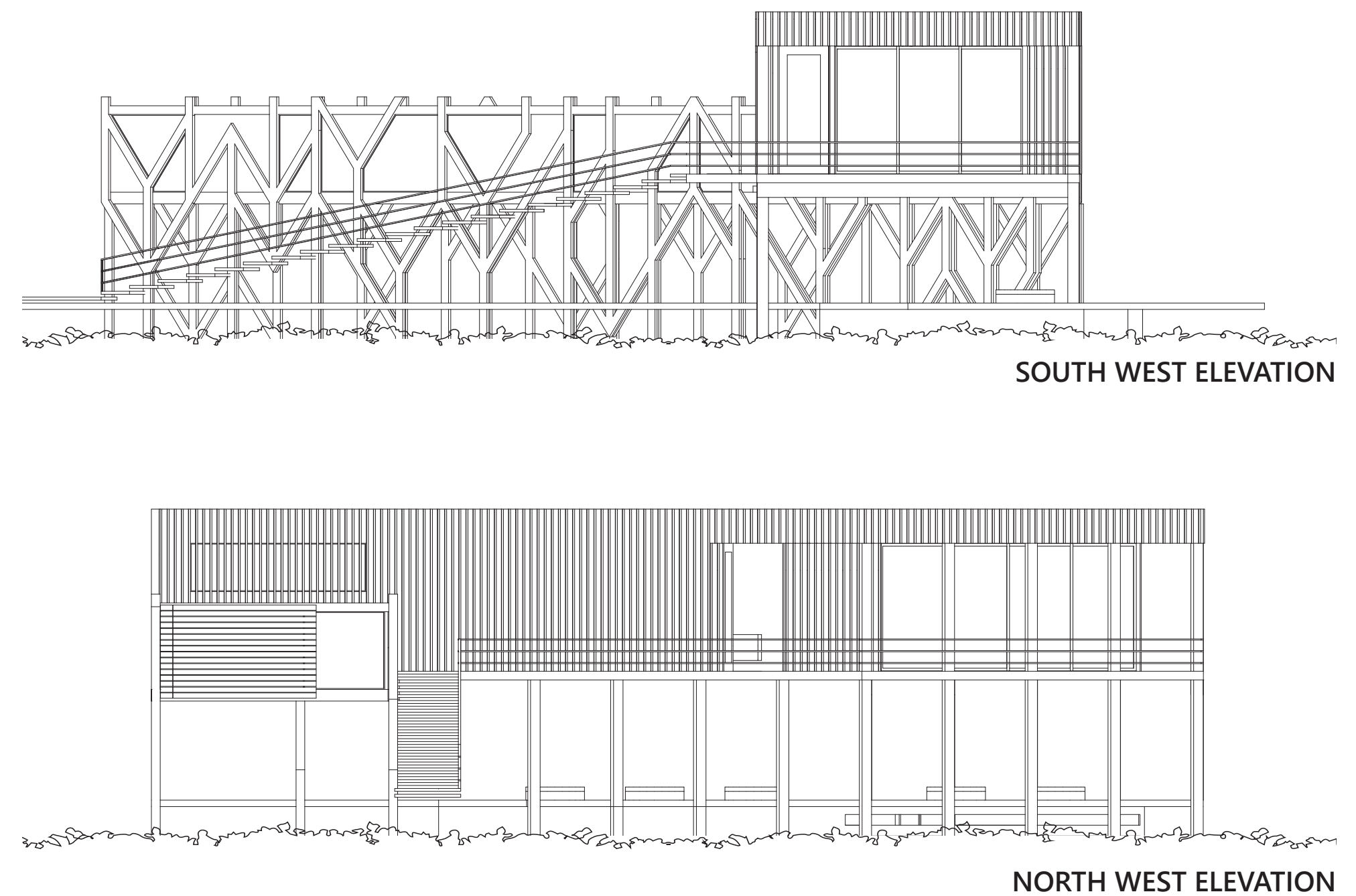


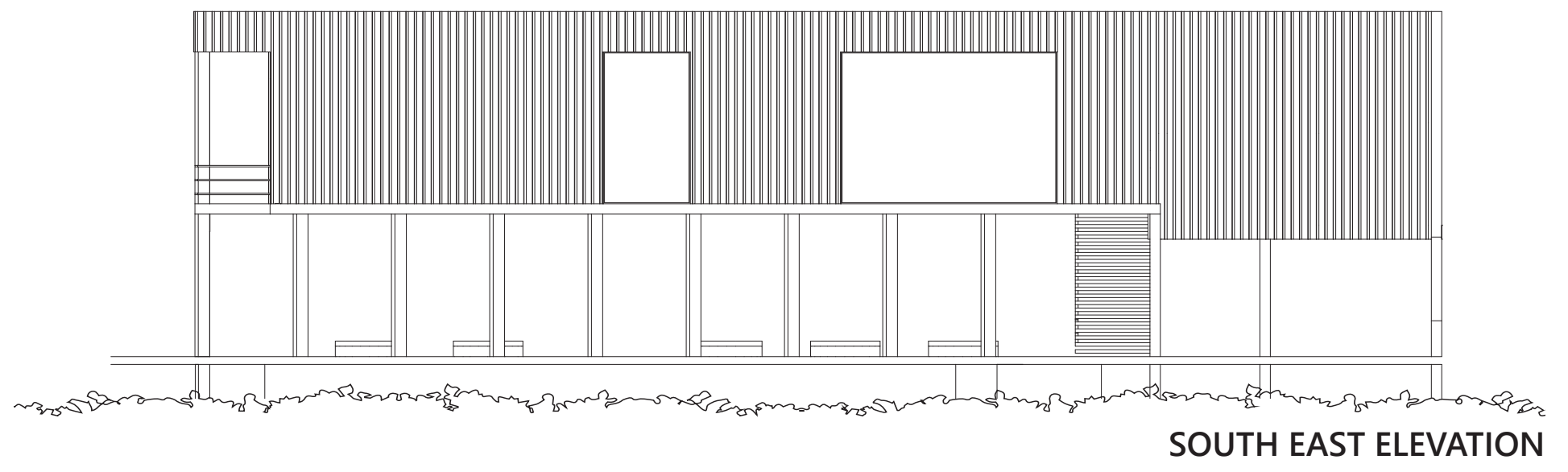

FIGURE 38

Elevations of ranger's hut

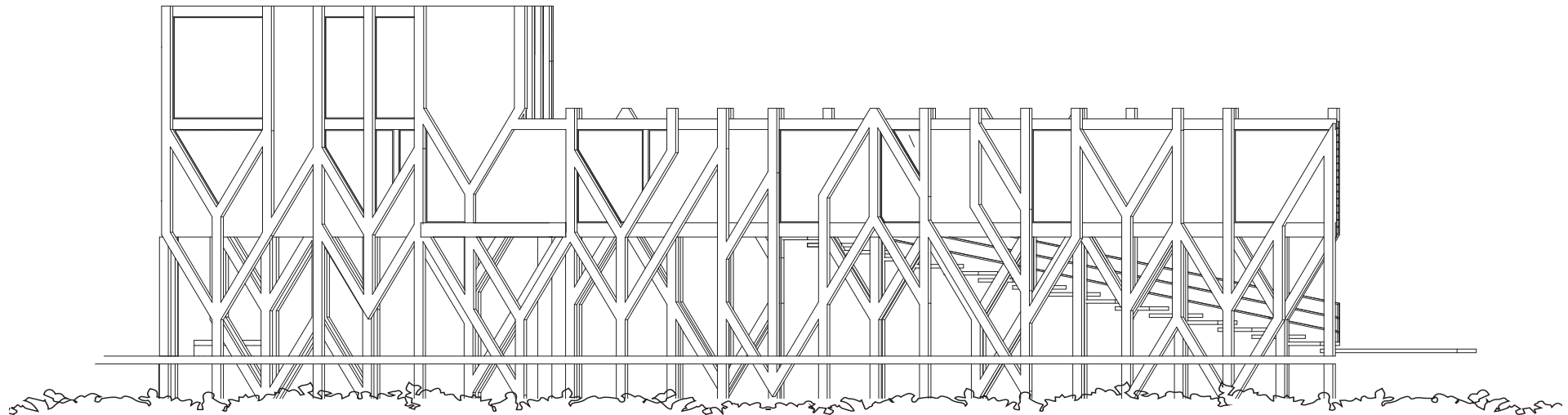

NORTH EAST ELEVATION 
The shelves.

Shelving system in the
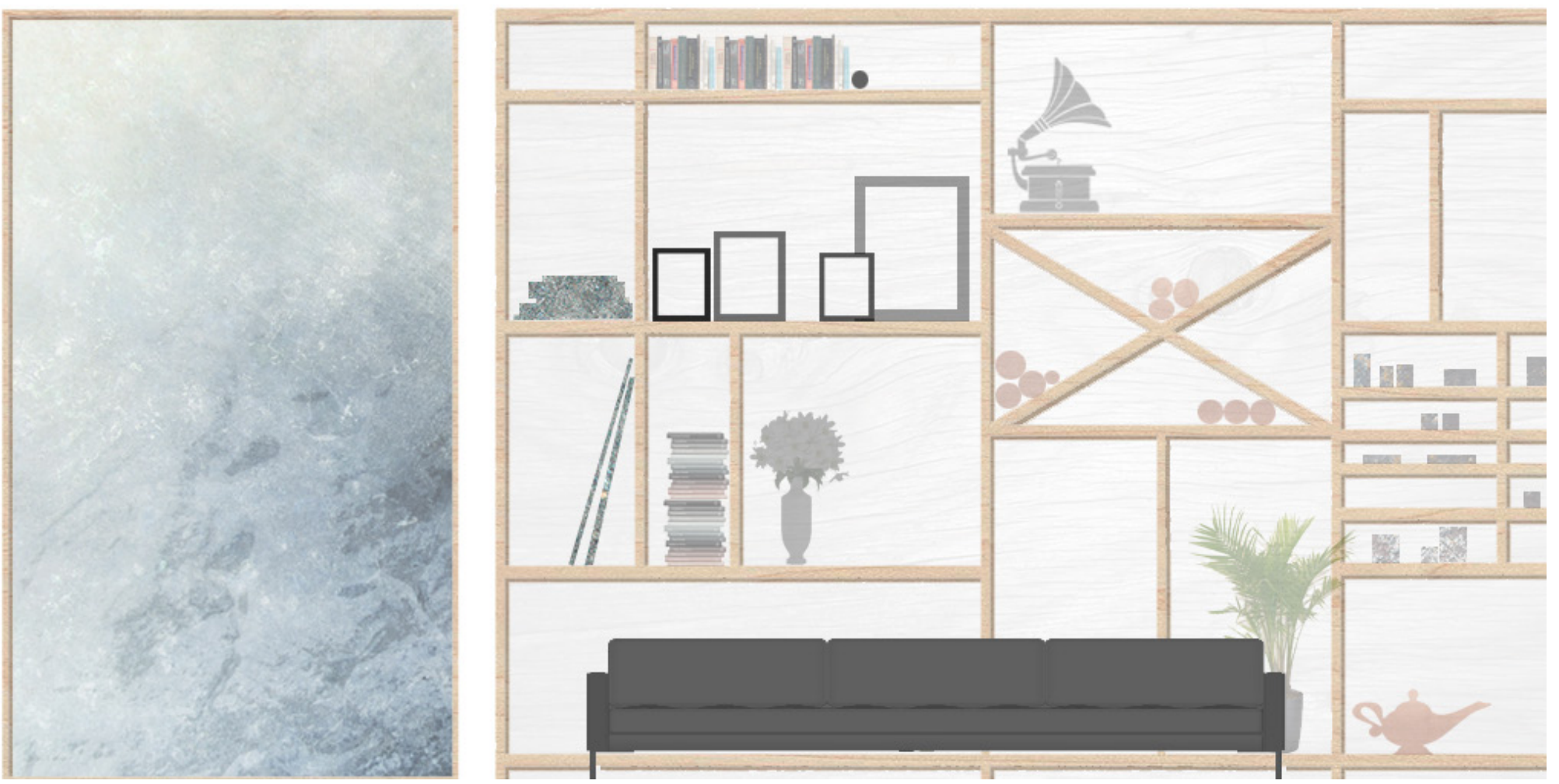

living areas to be filled

up with items gifted by guests. This represents the idea of a home as being a place which houses a person's belongings and as they are filled the home will begin to tell the story of not just the ranger's family but everybody who has stayed in the home. 


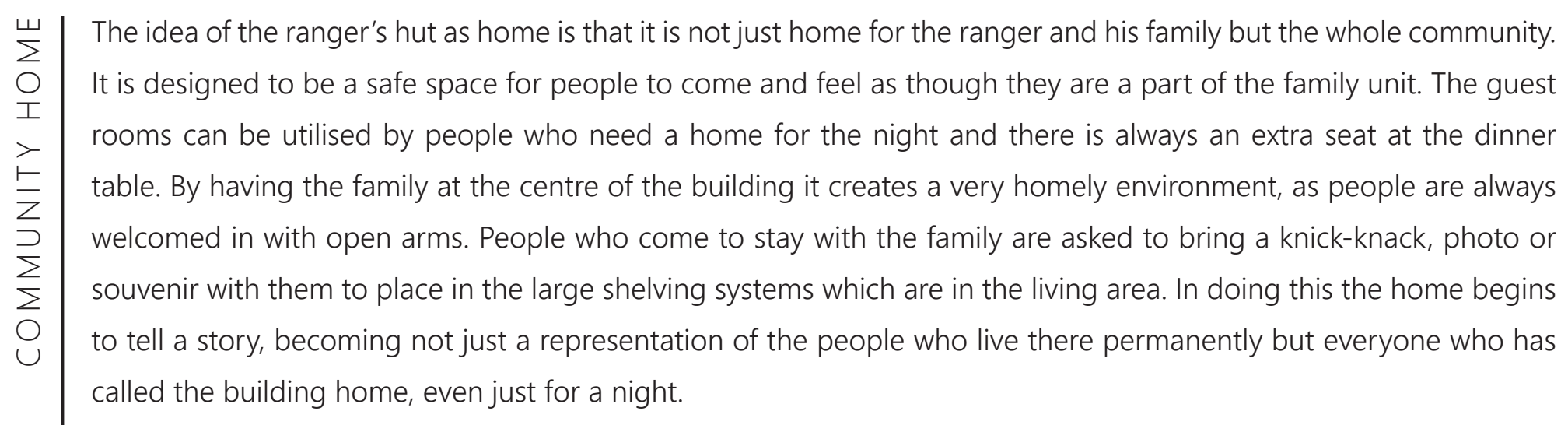




\section{RANGER'S HUT AS EMBASSY}

The term embassy is defined as a delegation or mission sent by one ruler or state to another. ${ }^{33}$ This is generally a representation of one country's government in another country. Their role is to transmit messages to the home government and inform them of important political, social, economic, military and other events which are taking place in the host country. It is also the embassy's job to promote their own home culture in the host country. ${ }^{34}$

To relate this to the role of the ranger's hut within the park, it will undertake the mission of spreading and promoting the importance of taking care of the environment to visitors of the park. It will act as a link between members of the environmental communities and the community of Kapiti as a venue to host people and events, as well as being an important learning centre.

${ }^{33}$ Oxford Dictionary, s.v. "Embassy," Accessed Jan. 10, 2017. https:// en.oxforddictionaries.com/definition/us/embassy

34 "What is the task of an Embassy?" Renaca. Accessed Jan. 10, 2017. http://www.renaca. ch/wasmacht-en.html 
The entry.

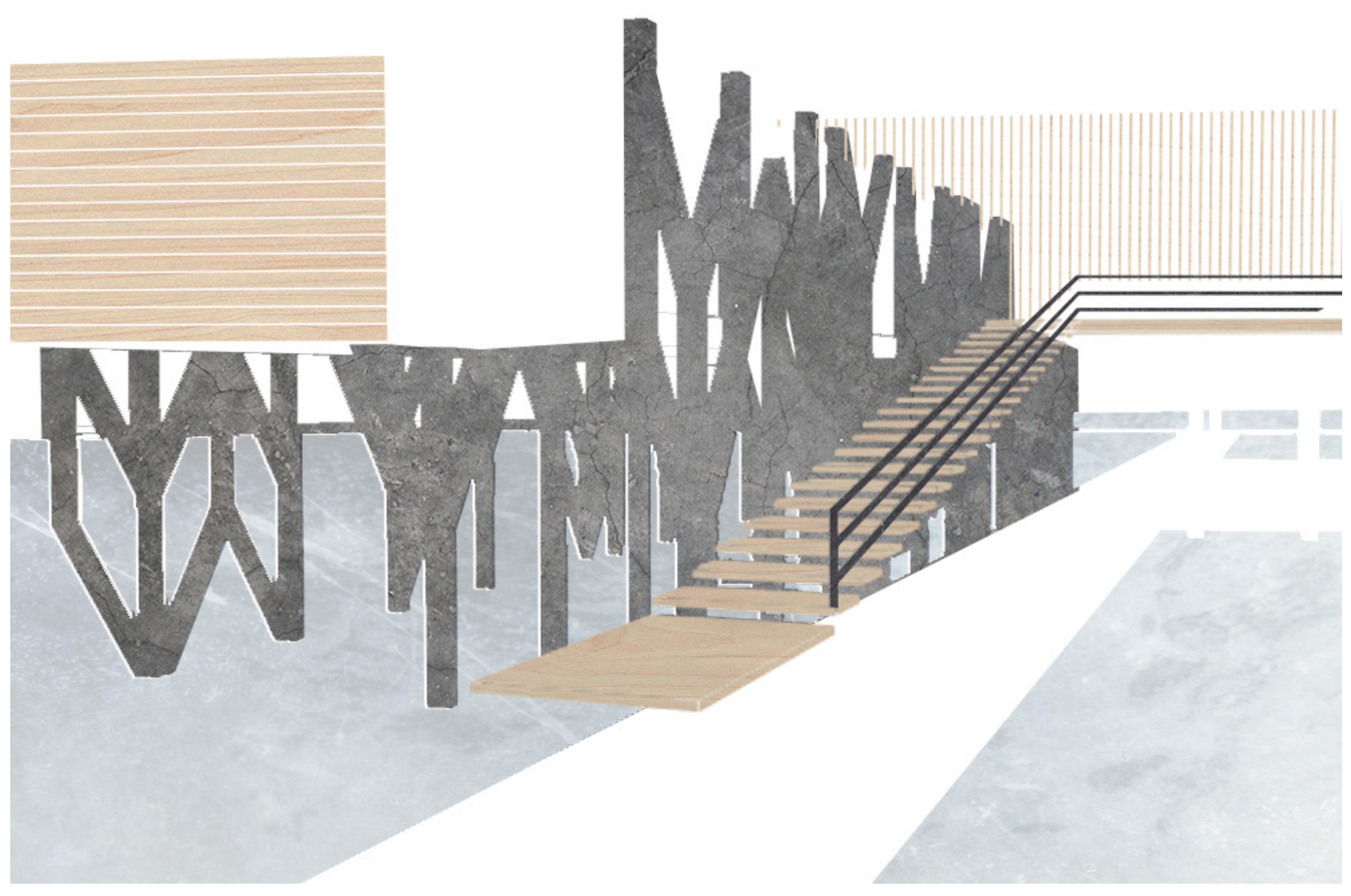

Stairs sitting adjacent to the boardwalk system enter up into the more private wings of the building. This entryway bears some of the grandeur that would typically be associated with an embassy entryway. 


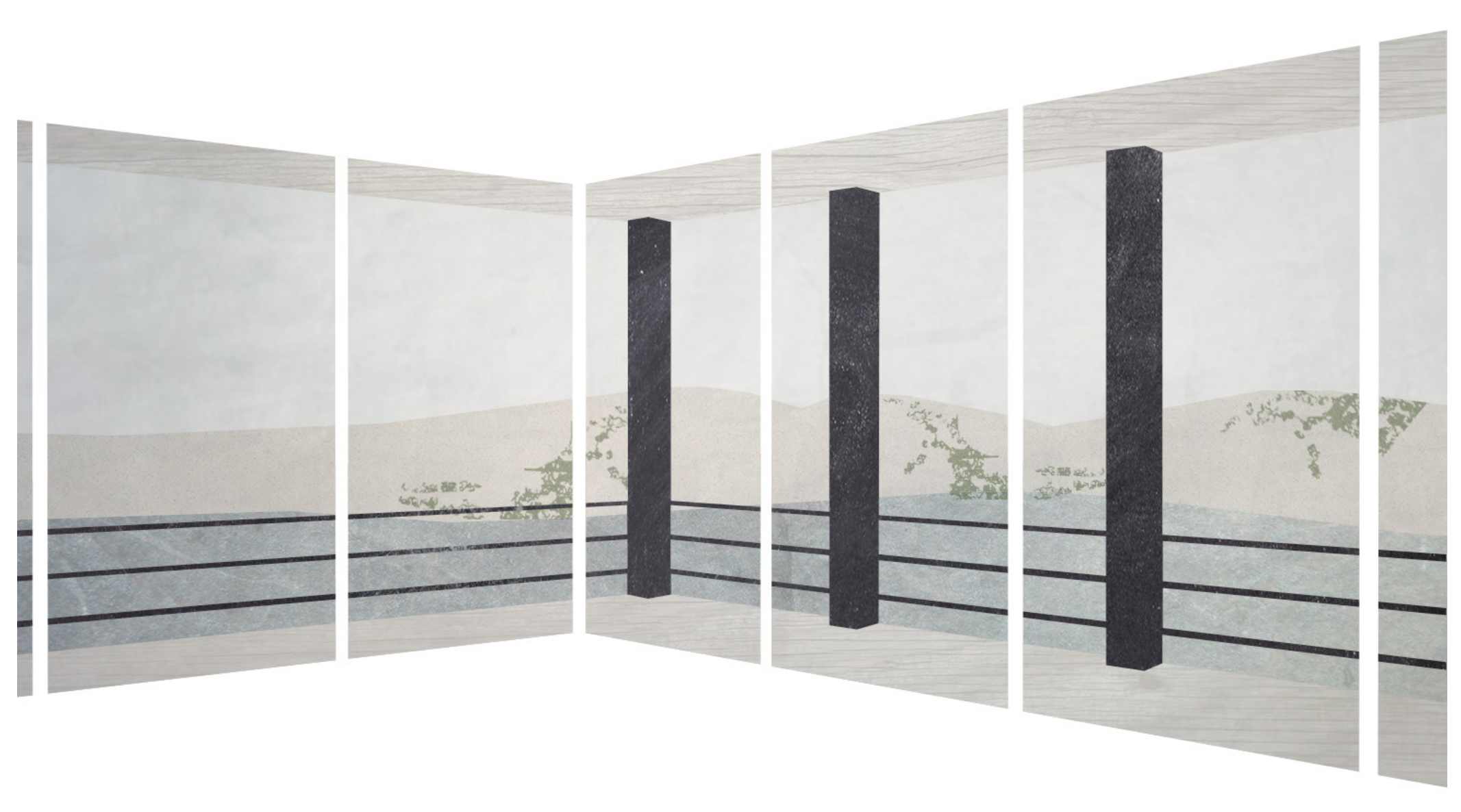

The watchtower.

Large windows in the

main living area look out over the park. Giving the ranger this vantage point allows him to keep watch over happenings in the park and aids in visitor safety. 
One of the benefits of having the ranger living at the park permanently, is that it creates a sense of custodianship. It is the ranger's role as custodian to guard, protect and maintain the park. The main home sitting up above the dunes acts as a watch tower and allows for the ranger to look out over the park. In doing this it aids in keeping the park a safe place for people to visit, knowing that there is always an authority figure present. He will work to make himself familiar with and create relationships with members of the community with the goal of encouraging them to approach him when issues do occur within the park. 
The dining table.

Large farm-style dining table sits at the centre of the home. It is the meeting point for the family where they come together, along with any guests, three times a day for meals and discussion. 
(v) A key role of an embassy is to host events and guests within the facility. This is achieved in the ranger's hut with $\leftleftarrows$ private guest sleeping quarters located within the home and versatile spaces which are able to adapt to suit different events. The guest bedrooms and bathroom share a hallway with the family bedrooms, divided by a small staircase. There is the capacity to sleep six guests at a time in this area, with an additional four able to be housed within vacated children's bedrooms if necessary.

Events that might be held in the building include banquets, exhibitions or seminars of various scales. In the case of a banquet or event including food, a secondary kitchen sits behind the main kitchen. This allows for the catering to be hidden from guests along with extra storage and oven space. The main living area is also easily cleared to seat large amounts of people at large tables or a provide ample standing space for more informal gatherings. Seminars and exhibitions may also be held within this space, or alternatively in the pavilion below or basement meeting rooms depending on their size. 

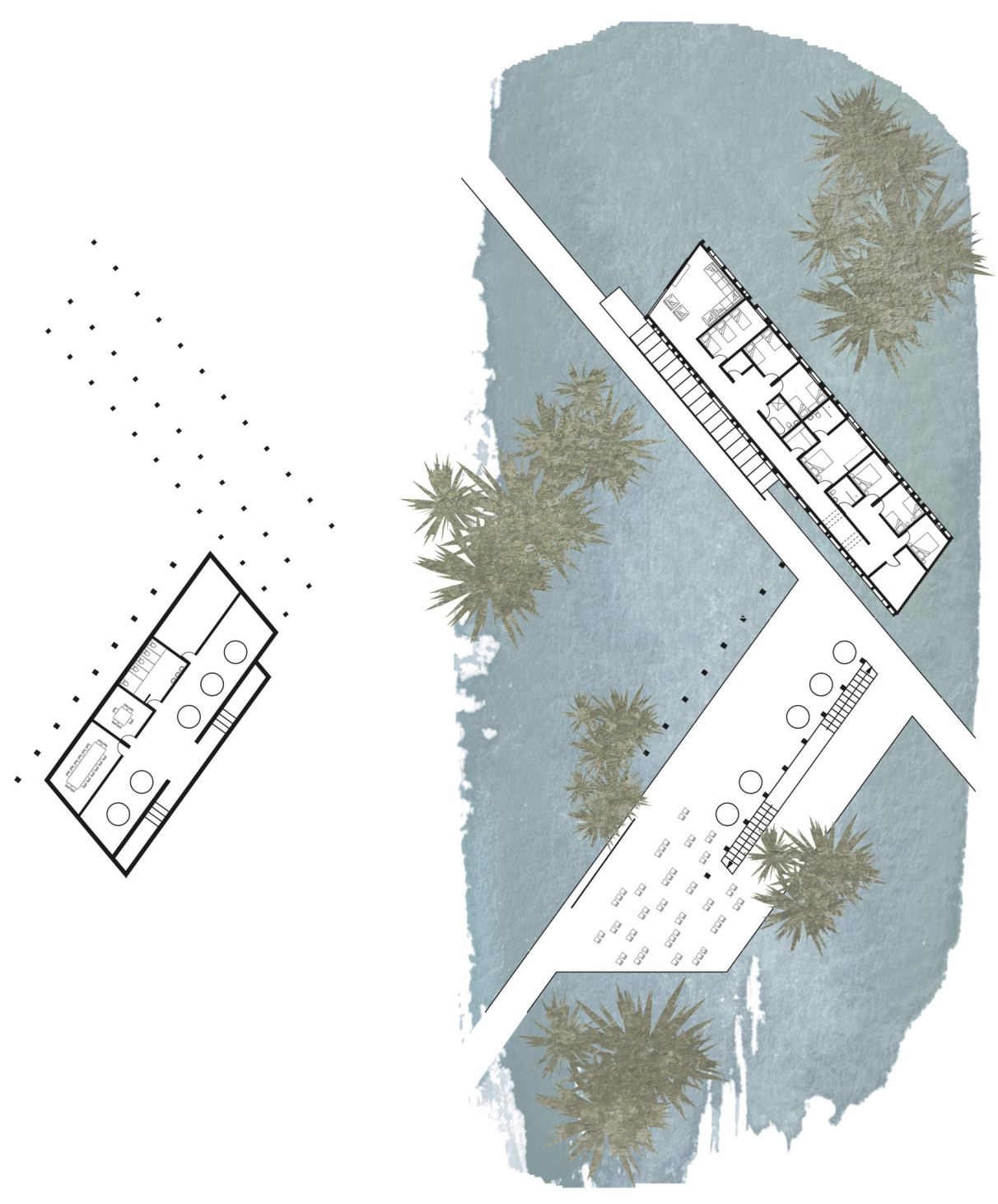

FIGURE 43

Movie night floor plans.

Floor plans highlight how the pavilion space might be used to host a largescale community event such as a public movie showing. 
FIGURE 44

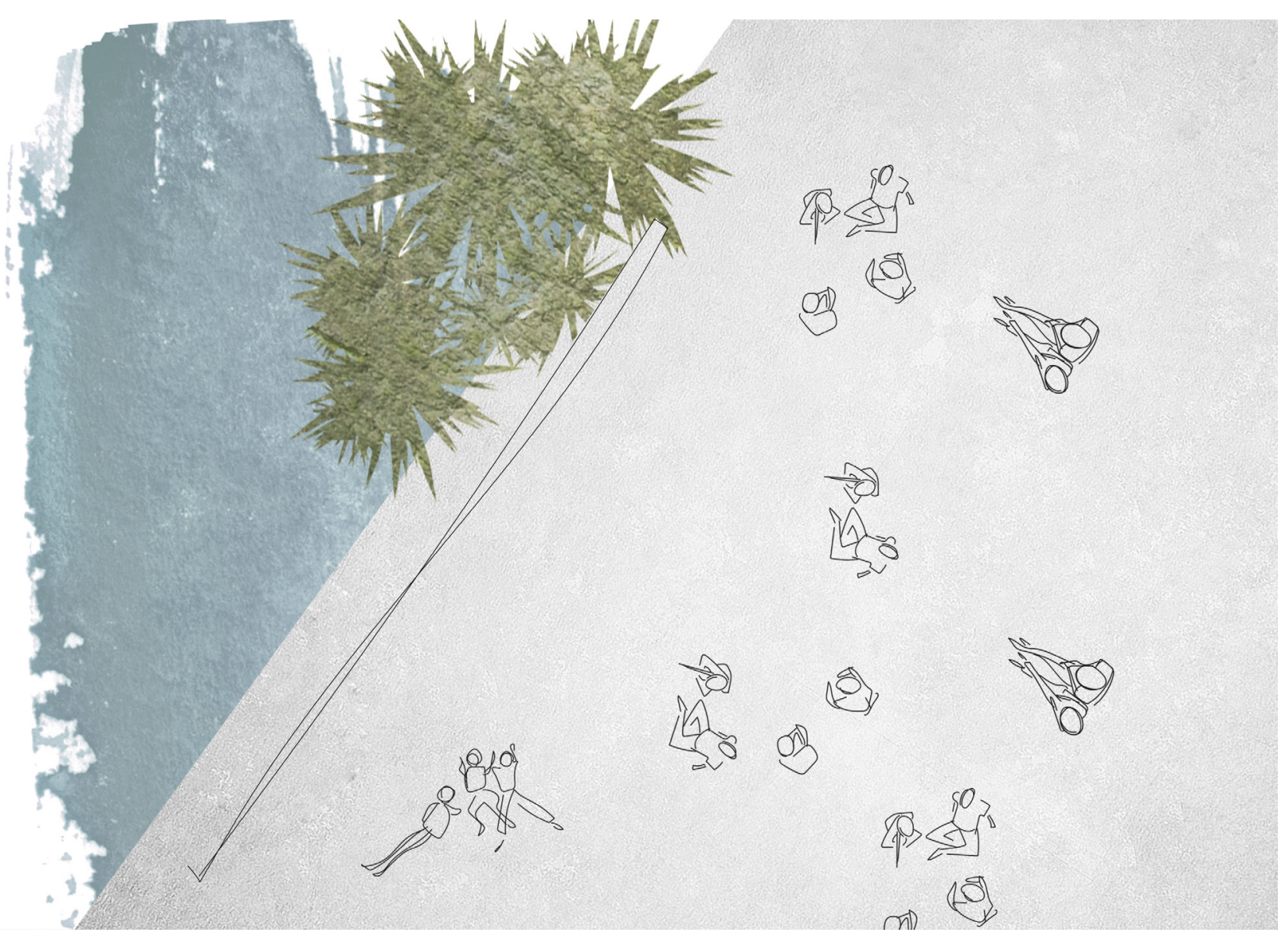

Community movie night.

Sketch highlights how people might occupy the pavilion during a community event such as a community movie night. A temporary screen would be erected, and guests encouraged to bring their own chairs or rugs. 

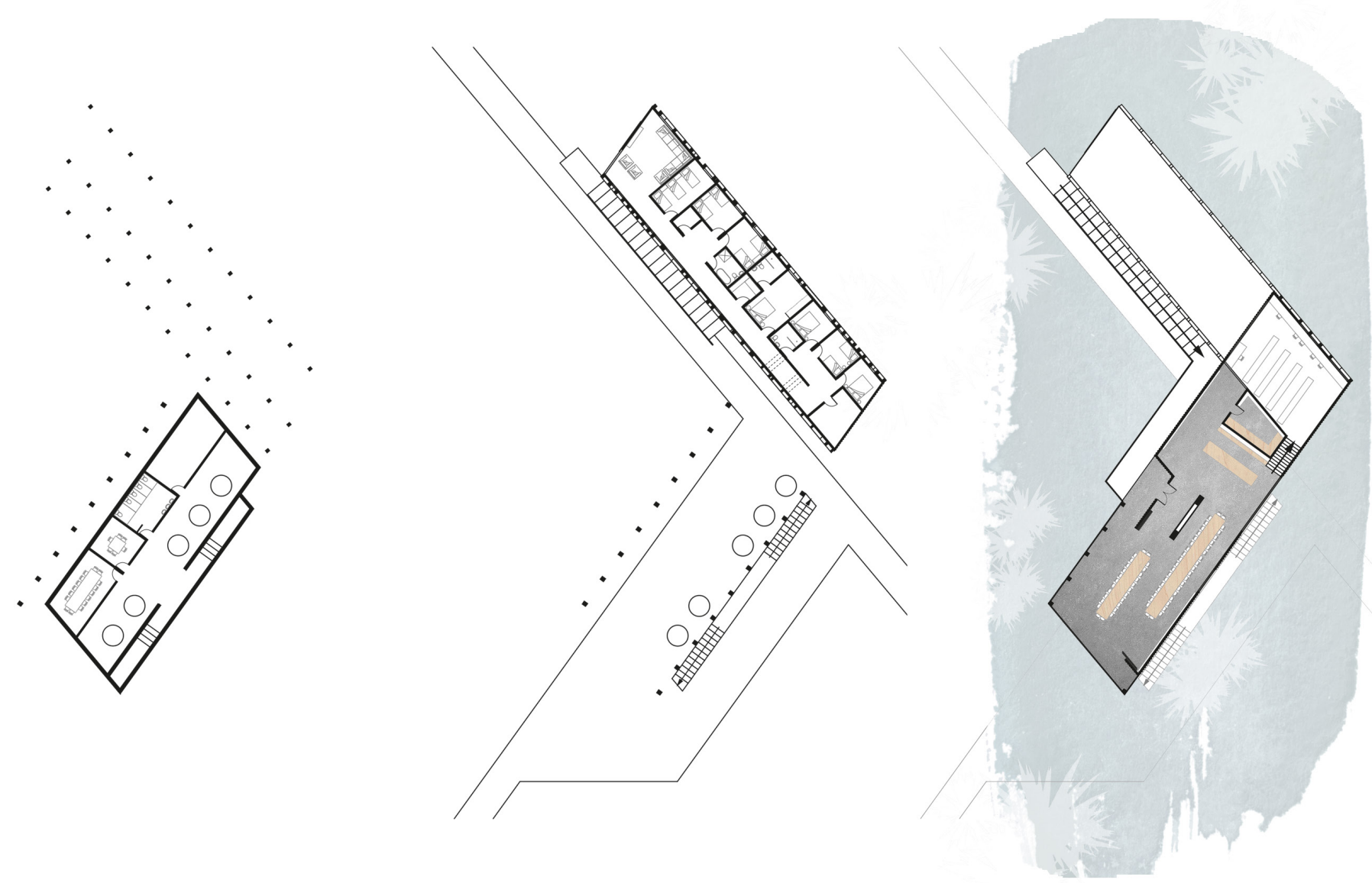

Banquet floor plans.

Floor plans showing how the building might be used to host a banquet. The secondary kitchen would also be used in this instance for food preparation, with the main kitchen acting as a bar. 
FIGURE 46

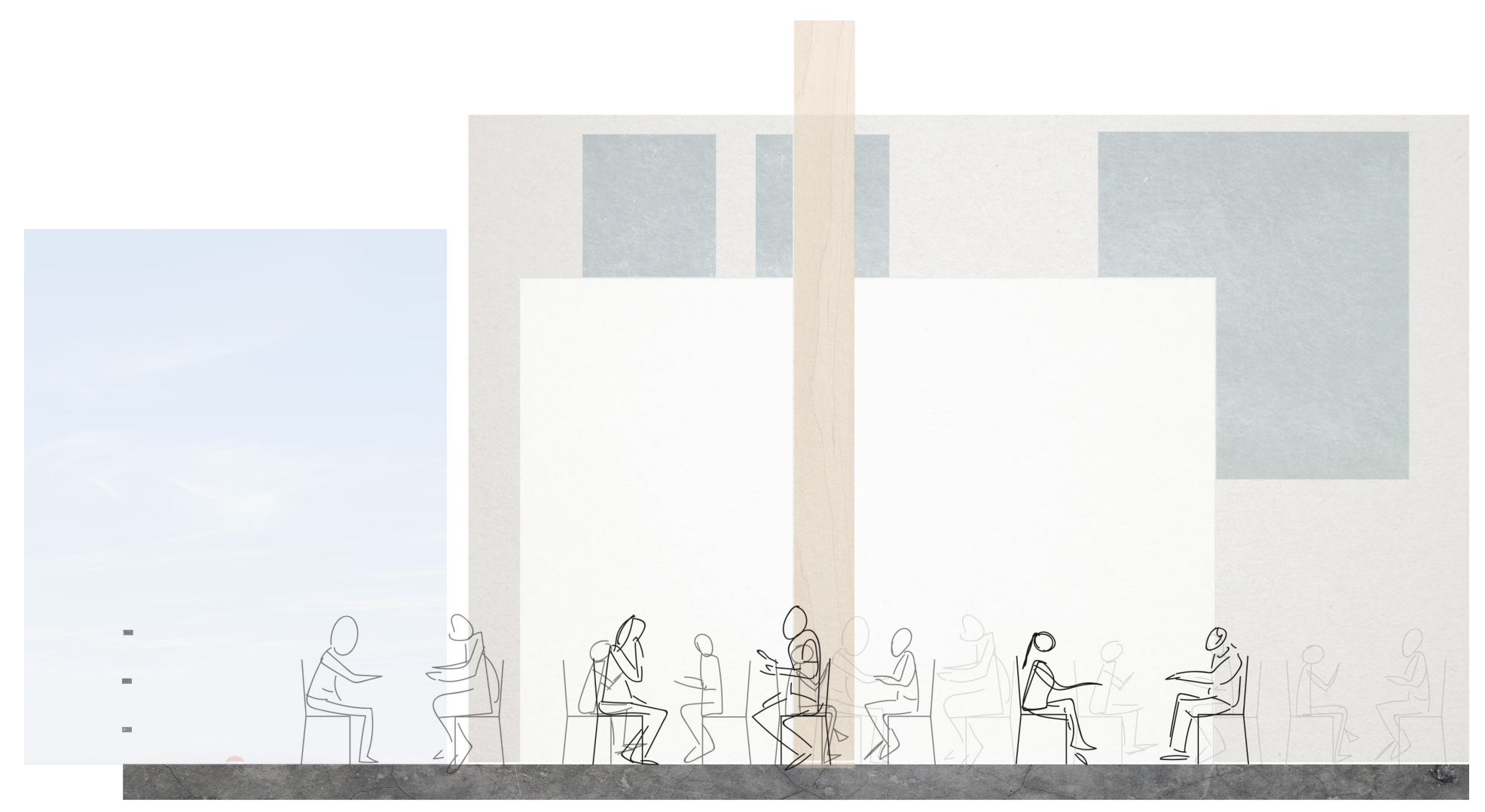

Banquet style event.

Section cut through the main living space shows how the main living space might be occupied during a banquet style event. The sliding doors being pulled back allows for more space and for a better connection with the outside. 
Learning styles.

\begin{tabular}{|c|c|c|c|c|c|c|}
\hline Visual & Aural & Verbal & Physical & Logical & Social & Solitary \\
\hline $\begin{array}{c}\text { Prefer using } \\
\text { pictures, images, } \\
\text { and spatial } \\
\text { understanding. }\end{array}$ & $\begin{array}{l}\text { Prefer using sound } \\
\text { and music. }\end{array}$ & $\begin{array}{c}\text { Prefer using words, } \\
\text { both in speech and } \\
\text { writing. }\end{array}$ & $\begin{array}{l}\text { Prefer using your } \\
\text { body, hands and } \\
\text { sense of touch. }\end{array}$ & $\begin{array}{l}\text { Prefer using logic, } \\
\text { reasoning and } \\
\text { systems. }\end{array}$ & $\begin{array}{l}\text { Prefer to learn in } \\
\text { groups or with } \\
\text { other people. }\end{array}$ & $\begin{array}{l}\text { Prefer to work } \\
\text { alone and use self- } \\
\text { study. }\end{array}$ \\
\hline $\begin{array}{l}\text { Clear water tanks } \\
\text { allow the benefits } \\
\text { of the water } \\
\text { treatment tanks to } \\
\text { be seen. Bringing } \\
\text { visitors to eye } \\
\text { level with water } \\
\text { also aids visual } \\
\text { learners. }\end{array}$ & $\begin{array}{l}\text { Seminar style } \\
\text { learning events } \\
\text { where guest } \\
\text { speakers come to } \\
\text { speak to large } \\
\text { groups. }\end{array}$ & $\begin{array}{l}\text { The meeting } \\
\text { rooms can } \\
\text { facilitate learning } \\
\text { events which are } \\
\text { based on group } \\
\text { discussions. }\end{array}$ & $\begin{array}{l}\text { Community } \\
\text { projects will } \\
\text { immerse visitors in } \\
\text { the site. This } \\
\text { includes the } \\
\text { community } \\
\text { gardens and } \\
\text { involving the } \\
\text { community in } \\
\text { wetland planting } \\
\text { and maintenance. }\end{array}$ & $\begin{array}{l}\text { The onsite library } \\
\text { provides resources } \\
\text { for logical } \\
\text { learners. It } \\
\text { contains written } \\
\text { information about } \\
\text { the systems on } \\
\text { site and as well as } \\
\text { other information } \\
\text { regarding coastal } \\
\text { inhabitation. }\end{array}$ & $\begin{array}{l}\text { Versatile spaces } \\
\text { enable a variety of } \\
\text { learning events to } \\
\text { be held in the } \\
\text { building. This } \\
\text { enables groups of } \\
\text { people who enjoy } \\
\text { this learning style } \\
\text { to come together } \\
\text { in the space. }\end{array}$ & $\begin{array}{l}\text { The library space } \\
\text { as well as meeting } \\
\text { rooms can be } \\
\text { used to facilitate } \\
\text { solitary learners. } \\
\text { This allows for } \\
\text { them to take part } \\
\text { in study without } \\
\text { being distracted } \\
\text { by other people. }\end{array}$ \\
\hline
\end{tabular}

Table shows definition of different learning styles and how these have been accounted for in the building design. 
$\cup$ In promoting care for the environment and an understanding of the impact of human activity on the landscape, $\bar{z}$ learning mechanisms are extremely important. The building has been equipped with a large library, teaching spaces $\stackrel{\Upsilon}{\varangle}$ and venues for seminars as well as designed with visual learning mechanisms. As discussed earlier, the building considers each of the 7 learning styles (visual, aural, verbal, physical, solitary, social and logical), as shown opposite. ${ }^{35}$ Through forced experiences, the way in which the building is inhabited, available resources and a variety of events it is hoped that everyone who visits the site will take gained knowledge away with them. 

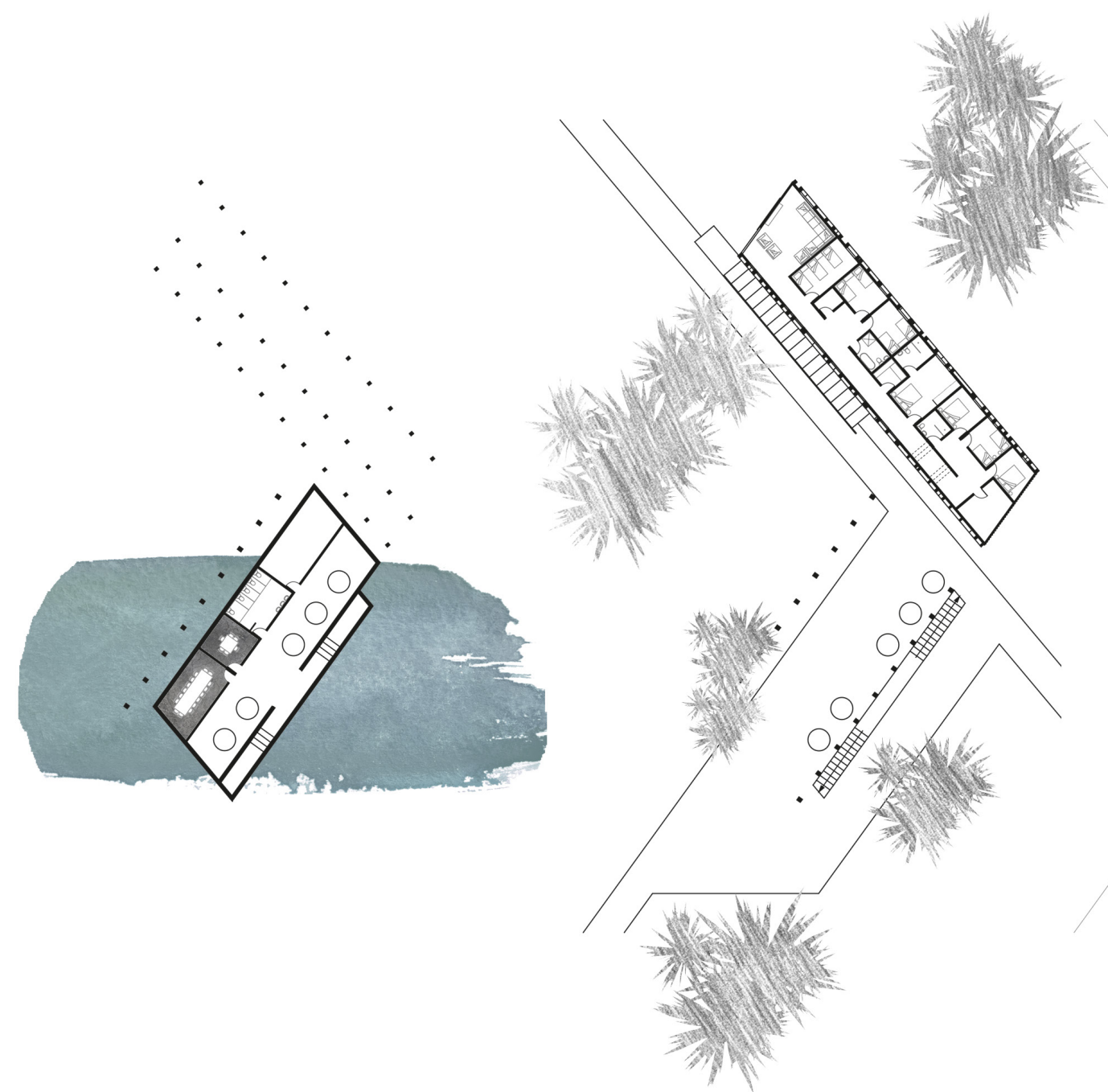

FIGURE 48

Solitary learning spaces.

Floor plans showing

spaces which can be

used to facilitate solitary

learning. The library space and meeting rooms can be used for people to work and study alone. 
Ranger's library.

The library houses the ranger's private collection. There is also a large study desk running along the back wall which allows for solitary study to take place. This space is mostly used by the ranger's children for their home schooling. 

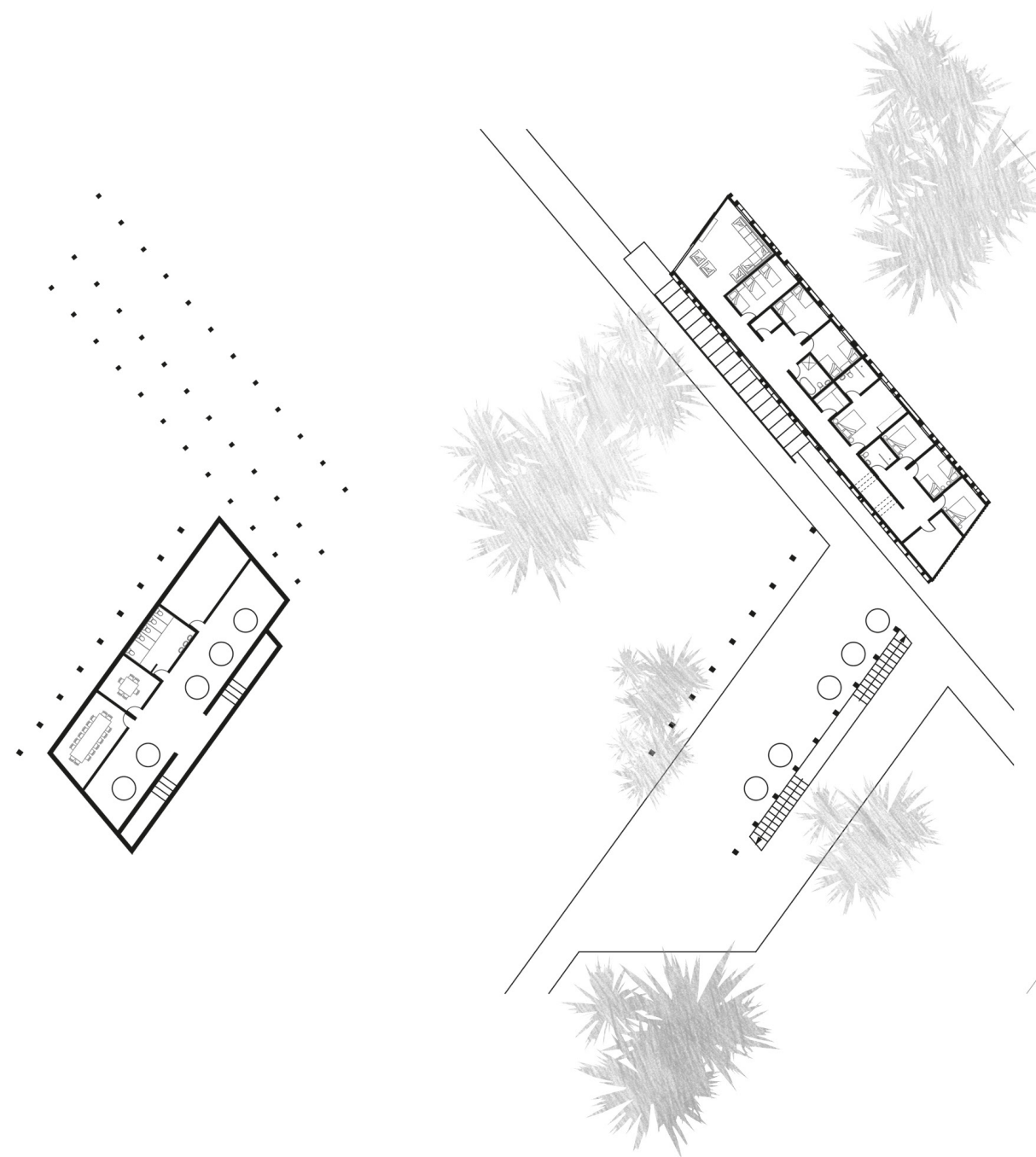

FIGURE 50

Social learning spaces.

Floor plans showing

spaces which can be

used to facilitate social

learning. Spaces can be

used to hold seminars,

meetings or events of a

range of sizes and styles. 


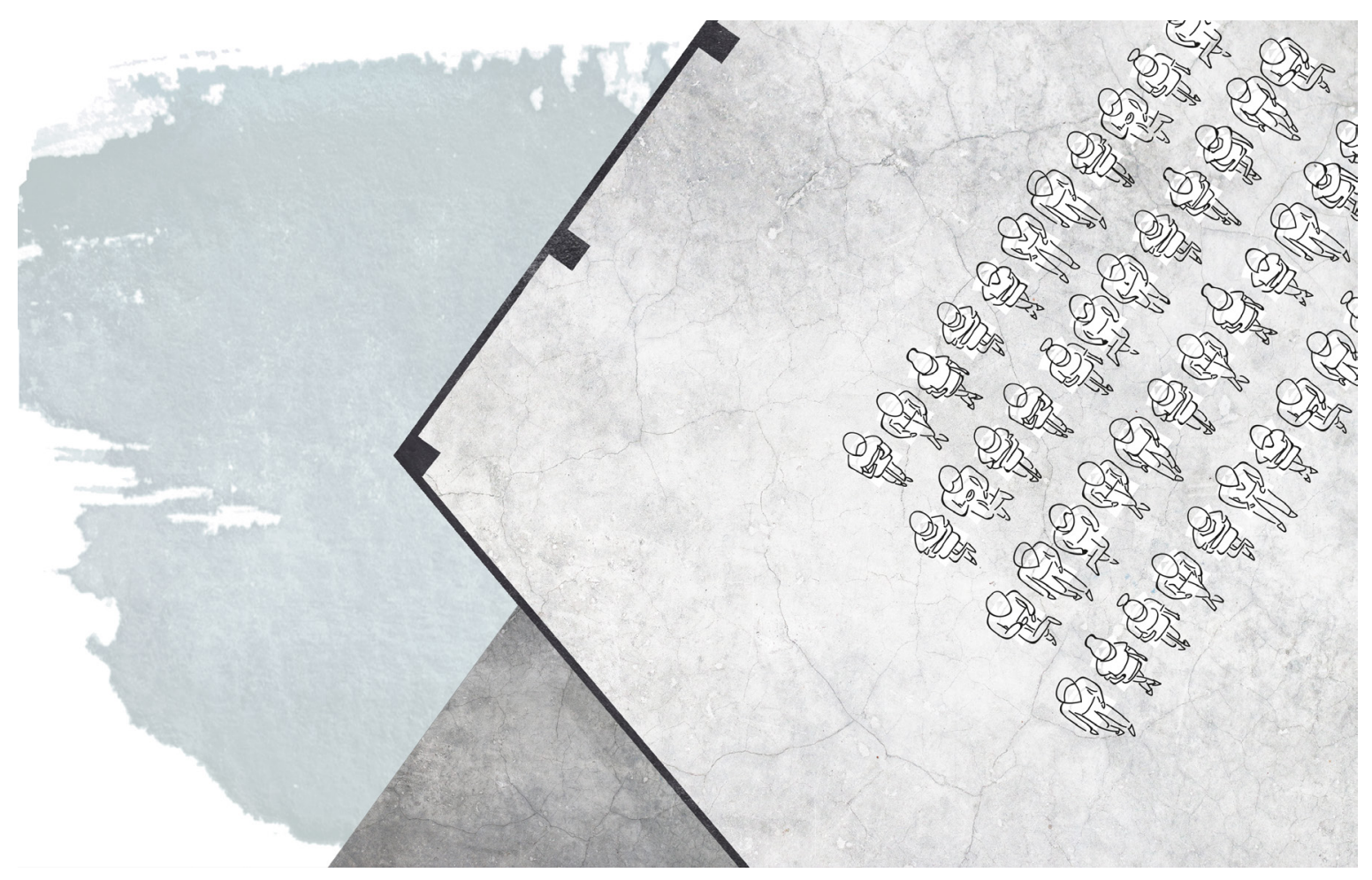

Large seminar style event.

The main living area can be cleared to facilitate large seminar style events where guest speakers are invited to speak in the space. 


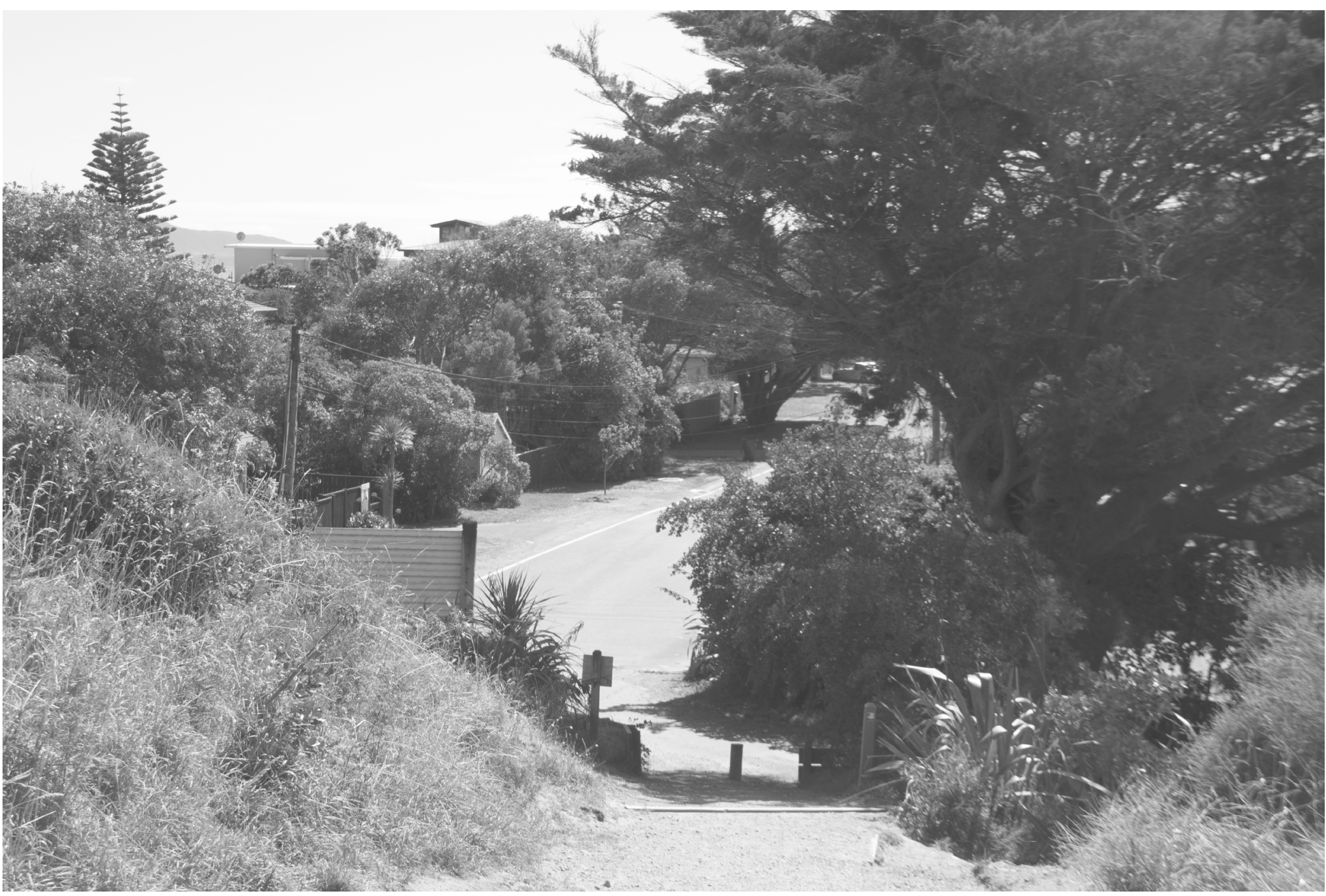

FIGURE 52

Current gateway.

Site image showing the current entrance to Queen Elizabeth Park from The Esplanade, Raumati South. 
The project also aids in creating a more appropriate entrance to the park. Common practice in New Zealand is to mark park entranceways with a piece of rope or chain between two posts, with the intention of keeping bikes and cars out. However, this strategy prevents it from being very inviting to pedestrians either. The current main Raumati entrance is a couple of bollards and an underwhelming gravel path up onto the dunes at one side, and a metal gate with a narrow gap alongside for pedestrians at the other.

In contrast, an embassy usually boasts a grand entrance and strong street presence. In comparison to this the new entrance to Queen Elizabeth Park from Raumati will be much more understated. The new entrance will link existing entranceways at McKenzie Avenue and The Esplanade with newly established community gardens. These large garden beds will be filled with seasonal fruit and vegetable plants and maintained by the ranger's wife as part of a community project. A concrete retaining wall will allow for a new pathway to sit alongside the dunes and guide visitors towards the track which will then link to the new boardwalk. The new gateway to the hut will be one of discovery rather than being confronted with the building immediately. 


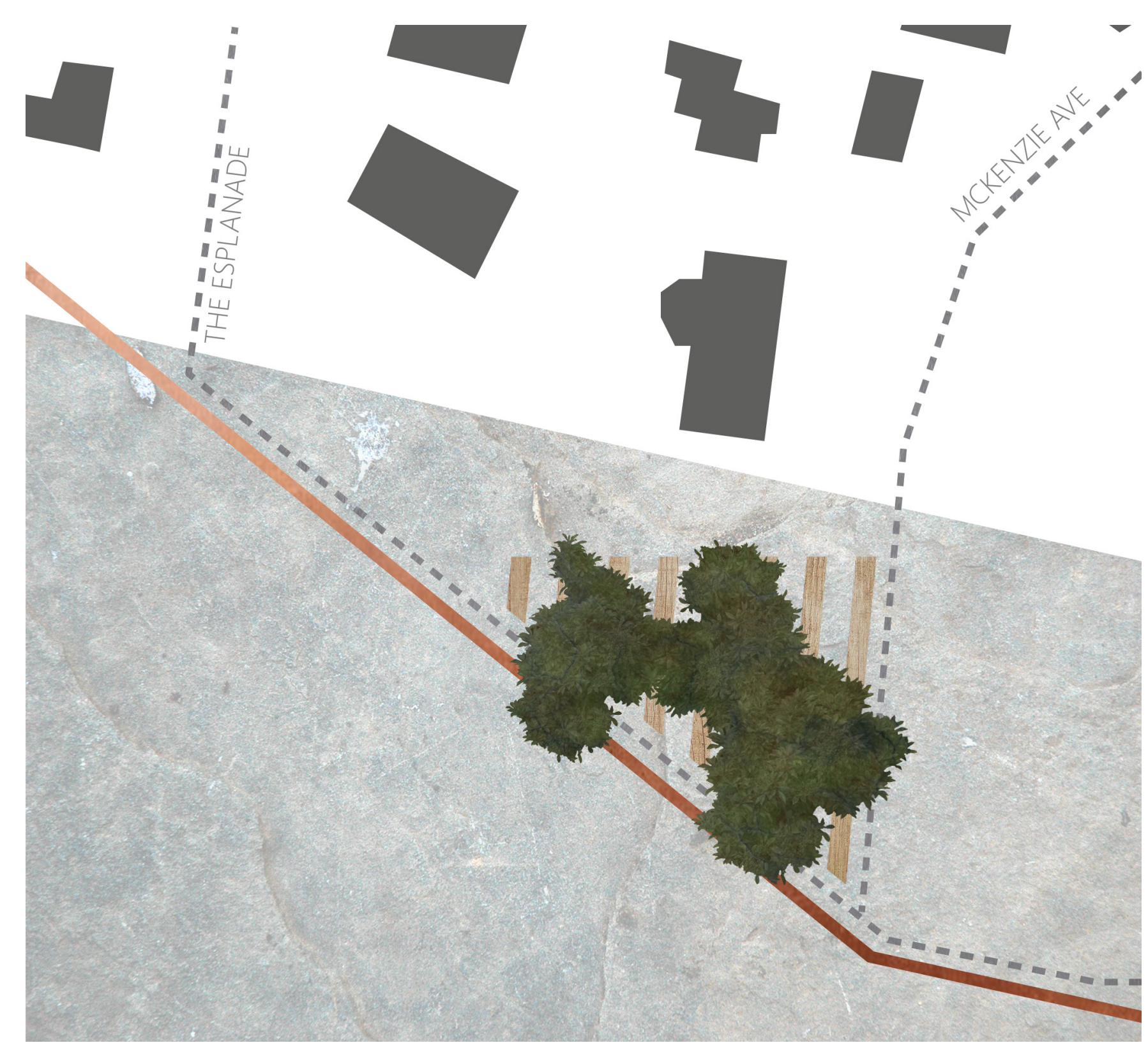

FIGURE 53

New gateway.

The new entranceway links the two main entrances from Raumati South to the park with a community garden. The retaining wall guides visitors along the walkways which link up to the boardwalk system. 


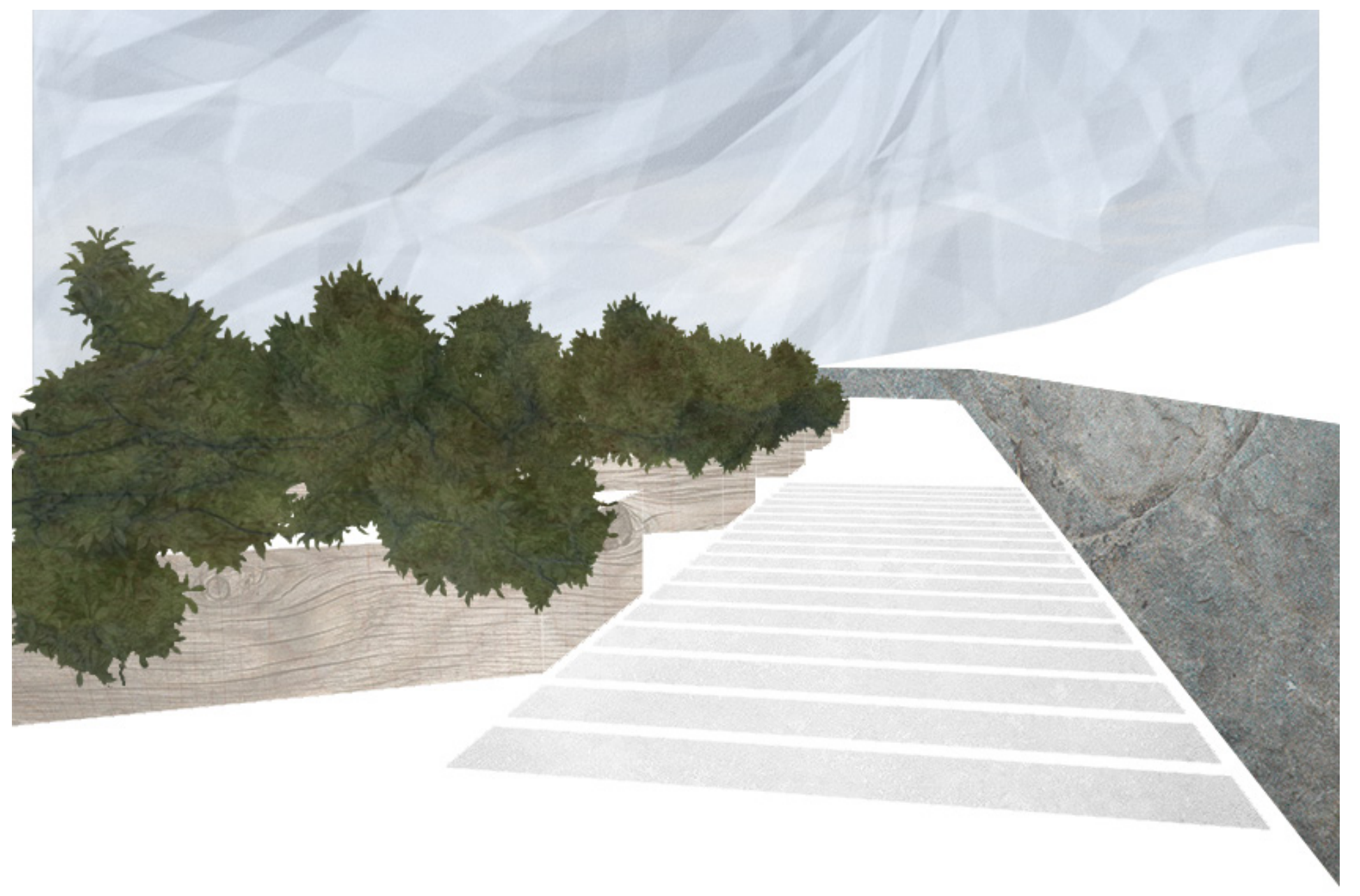

FIGURE 54

The community garden.

A new community garden will be established with freshly grown herbs, fruit and vegetables. Members of the community are encouraged to take the produce with the expectation that they help with the garden upkeep. 


\section{RANGER'S HUT AS CHURCH}

The word church, while now associated with the Christian religion, originates from the Greek word ecclesia which means a gathering of those summoned or a meeting of the people. ${ }^{36}$ The ranger's hut uses this concept in acting as a meeting place for people to come together, linking the communities at either end of the park and as being a venue for social interactions and events to take place.

The text From Temple to Meeting House also discusses the concept of a church as a meeting place, describing the church as being "The meeting between the divine and the human ... where communication between men and God had been opened up in a new way". ${ }^{37}$ The ranger's hut acts as a meeting point between humans and the environment, confronting visitors with the effects of human activity on the landscape and encouraging them to interact with the landscape in a new way.

36 "Ecclesia." Encyclopaedia Brittanica. Jul. 20, 1998. https://www.britannica.com/topic/ Ecclesia-ancient-Greek-assembly

${ }^{37}$ Turner, Harold. From Temple to Meeting House. Berlin/Boston: De Gruyter, 1979.

ProQuest Ebook Central. Page 138. 


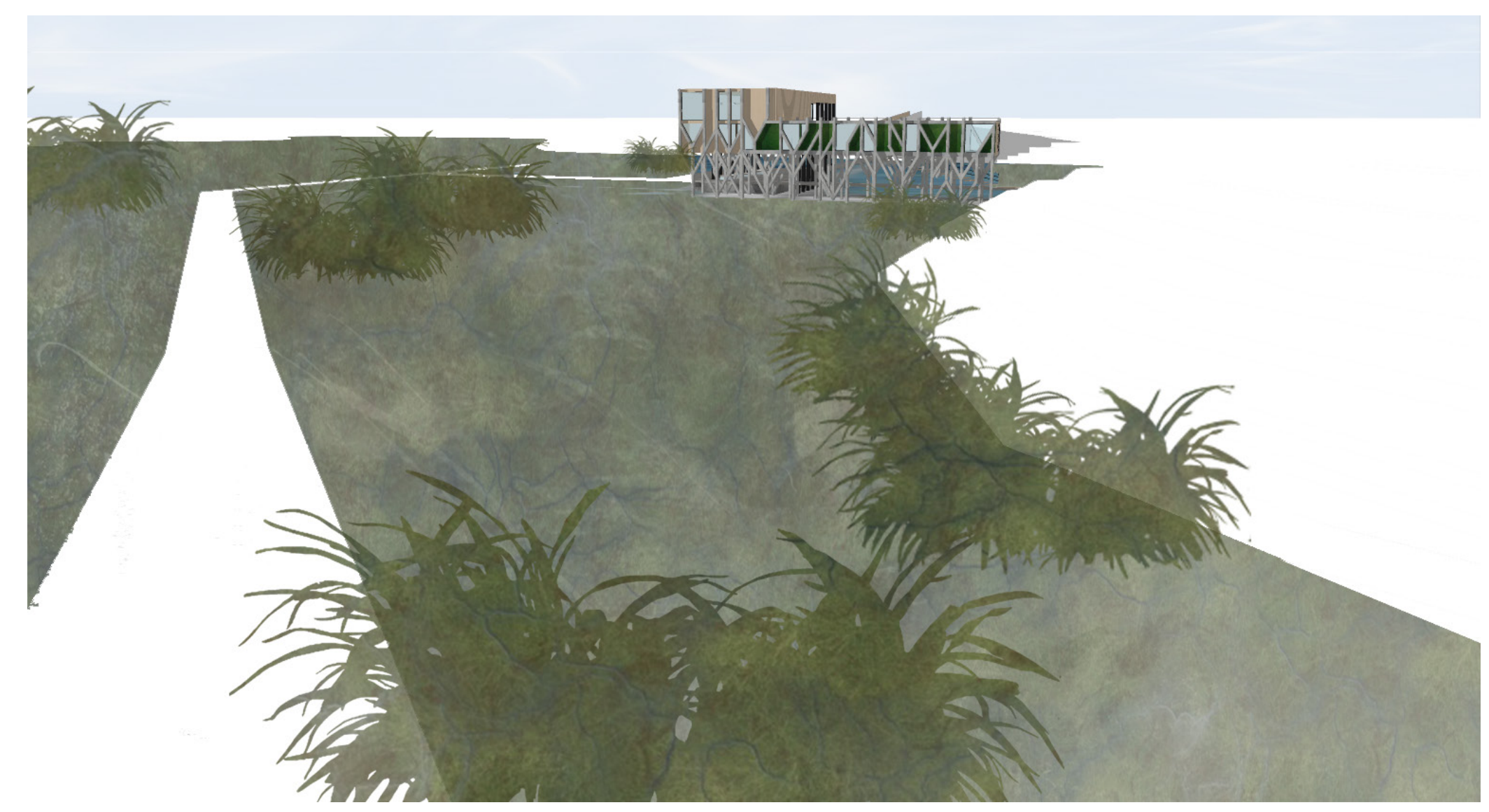

Rainbow Cres entrance.

The boardwalks link together the existing entrances from Raumati South. View of ranger's hut from Rainbow Cres entrance to the park. 

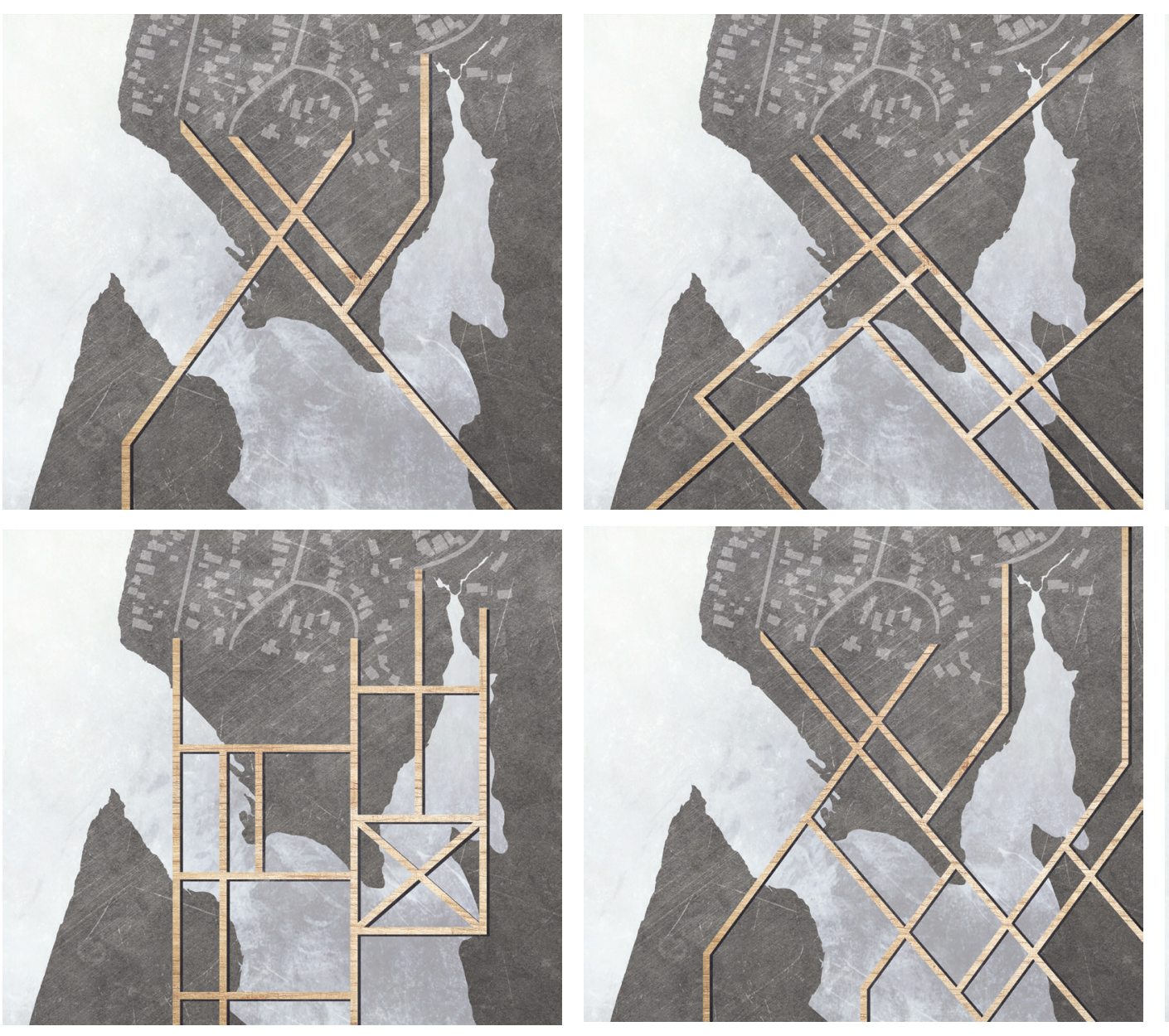
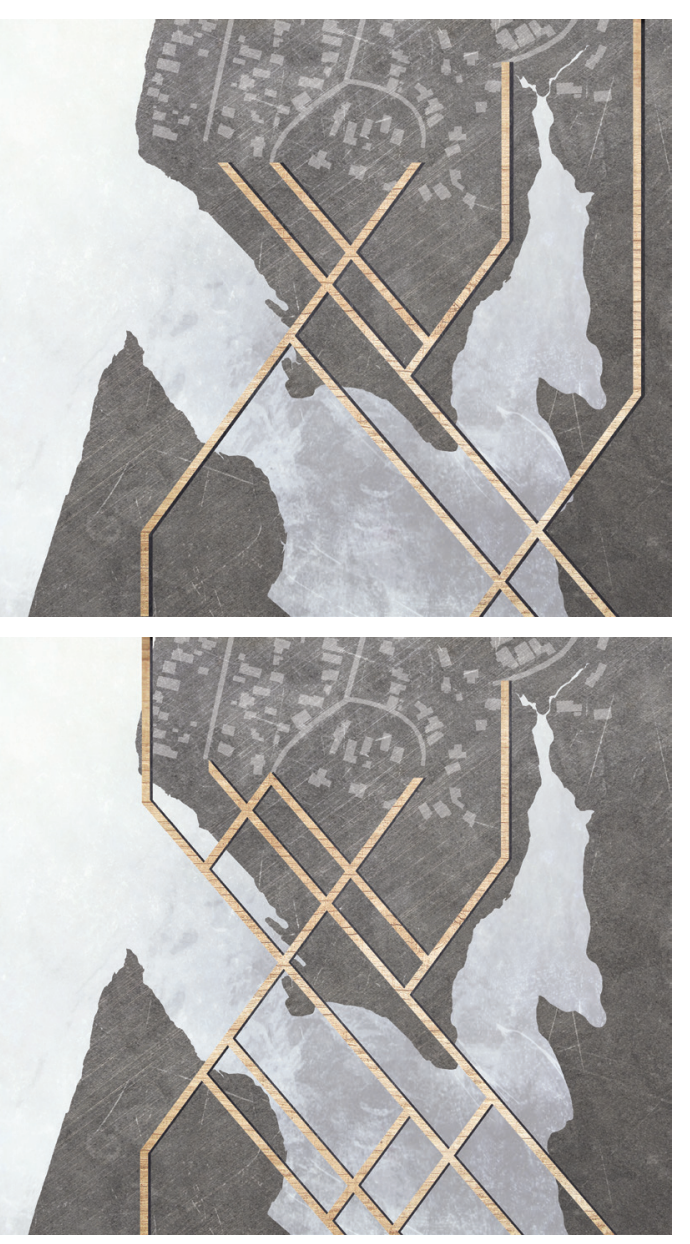

FIGURE 56

Bringing the community together.

Study looking at how a boardwalk system can be used to bring people together from different areas of the community and reconnect Raumati South to Queen Elizabeth Park. Iterations revealed that the boardwalk system was much stronger with less strands rather than using many which confuses the space. 
The project acts as a meeting place by establishing a system of boardwalks and walkways within the park. Due to the reinstatement of the wetlands cutting off the existing pedestrian access from Raumati south, the main access to the beach or rest of the park is now by crossing the boardwalks and entering through the ranger's hut. The boardwalk draws together people entering the park through the walkways at the southern end of Raumati South to one central axis point on which the building lies. The boardwalks then disperse from this point to provide access down to the beach by connecting to the existing walkways as well as leading people toward the middle of the wetlands where there is a viewing area. The ranger's hut therefore acts as a meeting place by physically bringing all visitors to the park to one point on which the ranger's hut lies.

In its role as a meeting place, the ranger's hut will become a venue for community events and gatherings. The pavilion space allows people to come together in one place, share in conversation, food and activity. People are free to come and sit in the space, or venture further out in the park, to exercise together, have picnics together or simply spend time together. Events will also be hosted by the ranger such as movie nights or sports game screenings, all with the purpose of bringing members of the community together and strengthening relationships. 


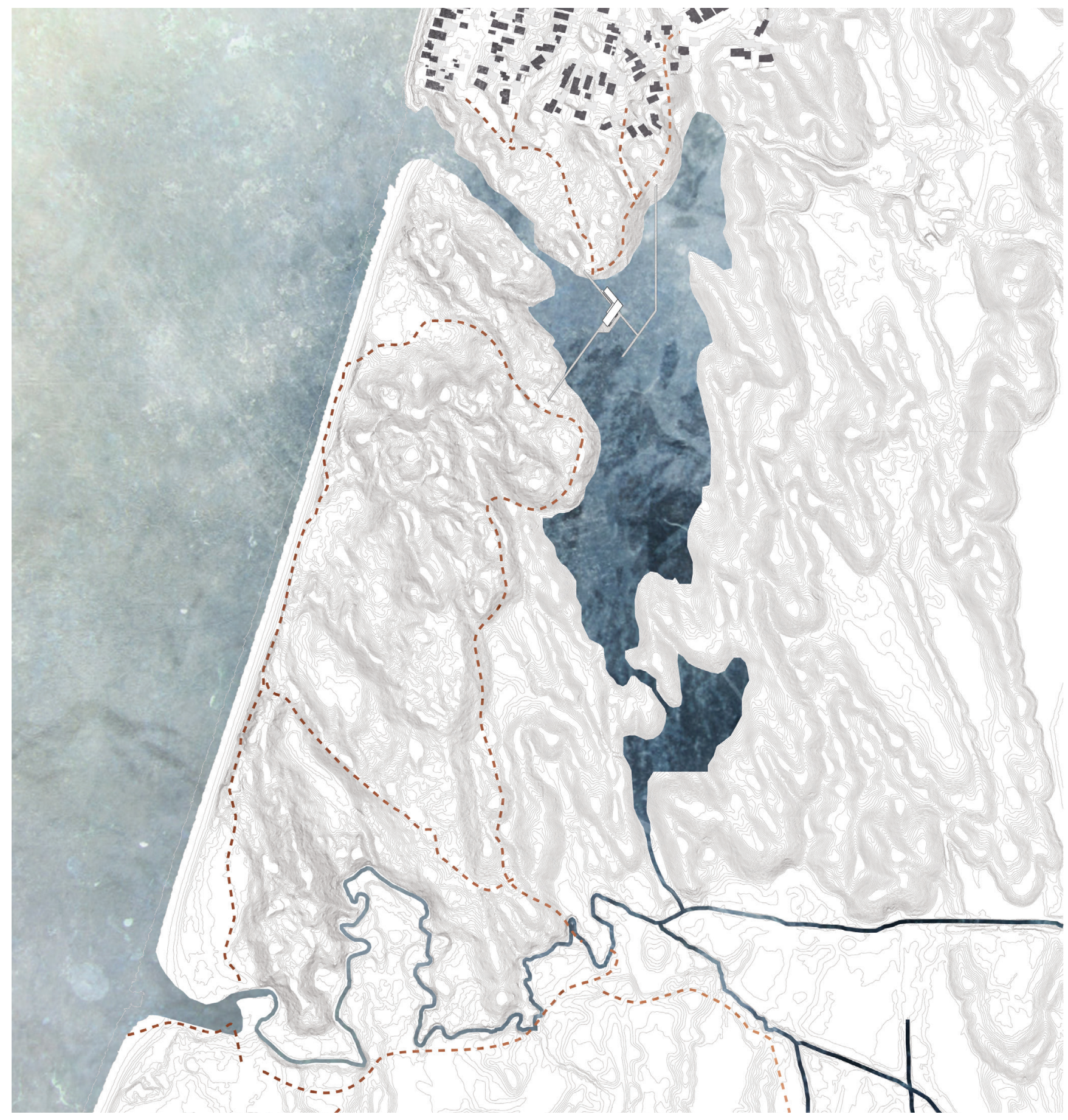

FIGURE 57

Site Plan.

Aerial view of ranger's hut and boardwalk system sitting over wetlands. Shows how the boardwalks link to the dune walkways. 


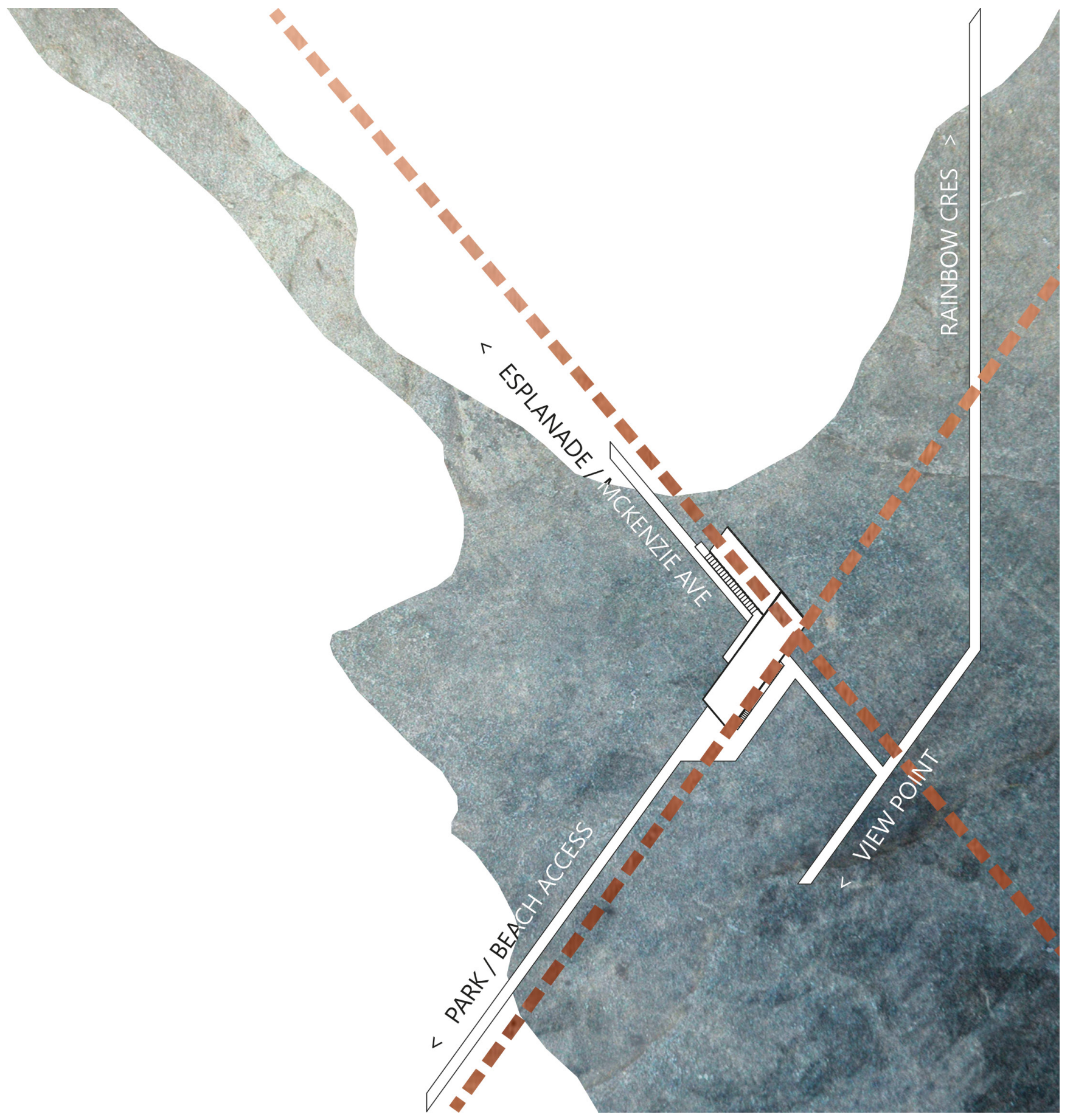

FIGURE 58

Ranger's hut on axis.

The ranger's hut lies right on the axis of the boardwalk system, encouraging visitors to pass through the building. 

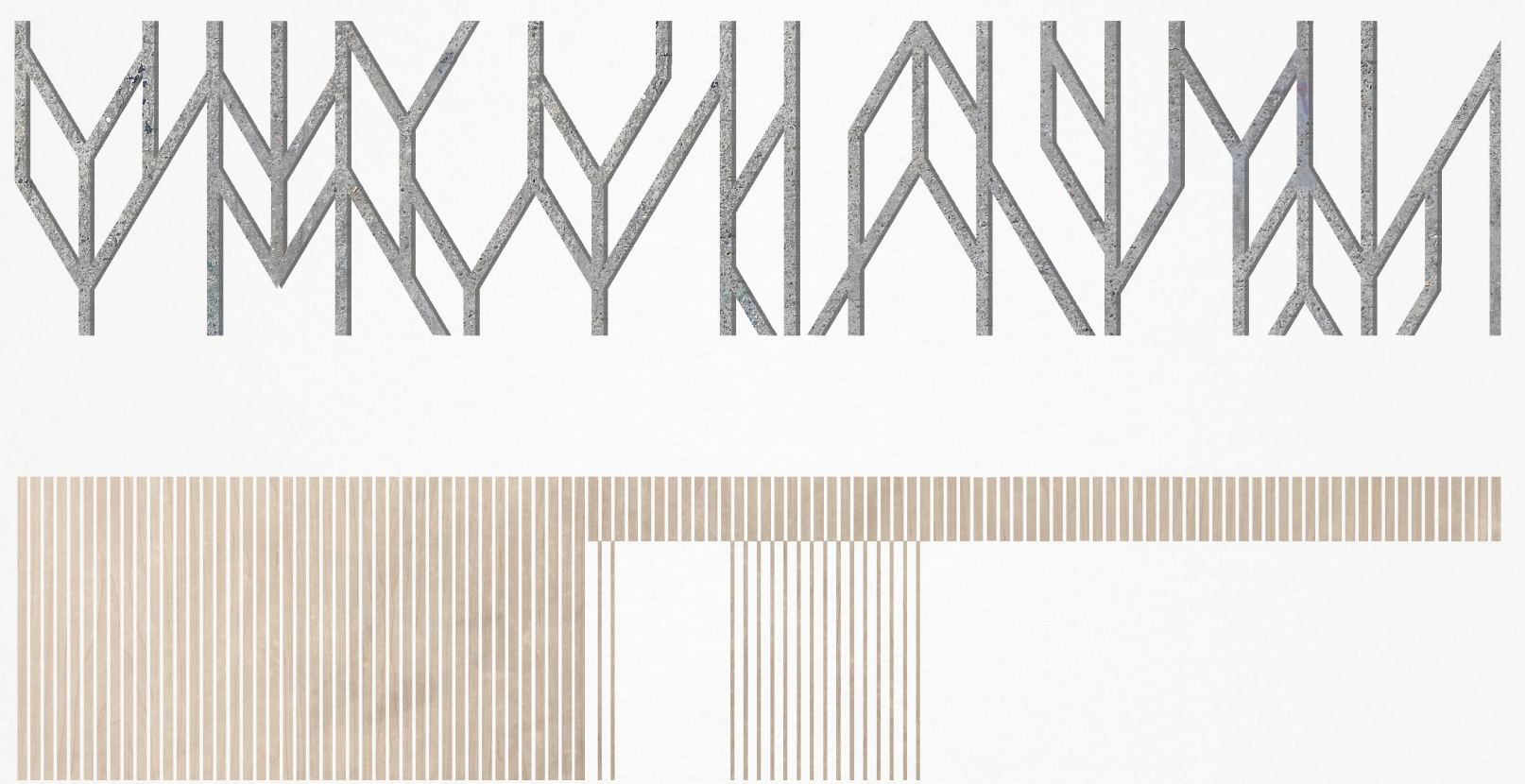

History in façade.

The different wings represent different eras in the sites history. The top represents the forests during Maori inhabitation, middle represents the European settlement of the site as farmland and bottom bunker-like space represents the site being used as a US Marine's training camp. 
Churches also play the role of honouring past events and making people aware of what once was. This is reflected in the ranger's hut through the building design and the wetlands themselves. As discussed earlier, the wetland reinstatement honours the site as it would have once been prior to European settlement. The wing of the building in which the bedrooms sit also celebrates this period with the supporting column and bracing system designed to resemble the forest that would have once covered the site prior to the land being cleared. The contrasting wing of the building represents the European settlement of the site as farmland. It's timber design with large fireplace is reminiscent of a farm house, and the tradition of these buildings having large dining tables as the centre of the home has been replicated. Thirdly the period during World War II when the park was home to the US marines has been honoured with the design of the basement level which resembles the concrete bunker systems that were constructed in various parts of the country around this time. 
Public seating.
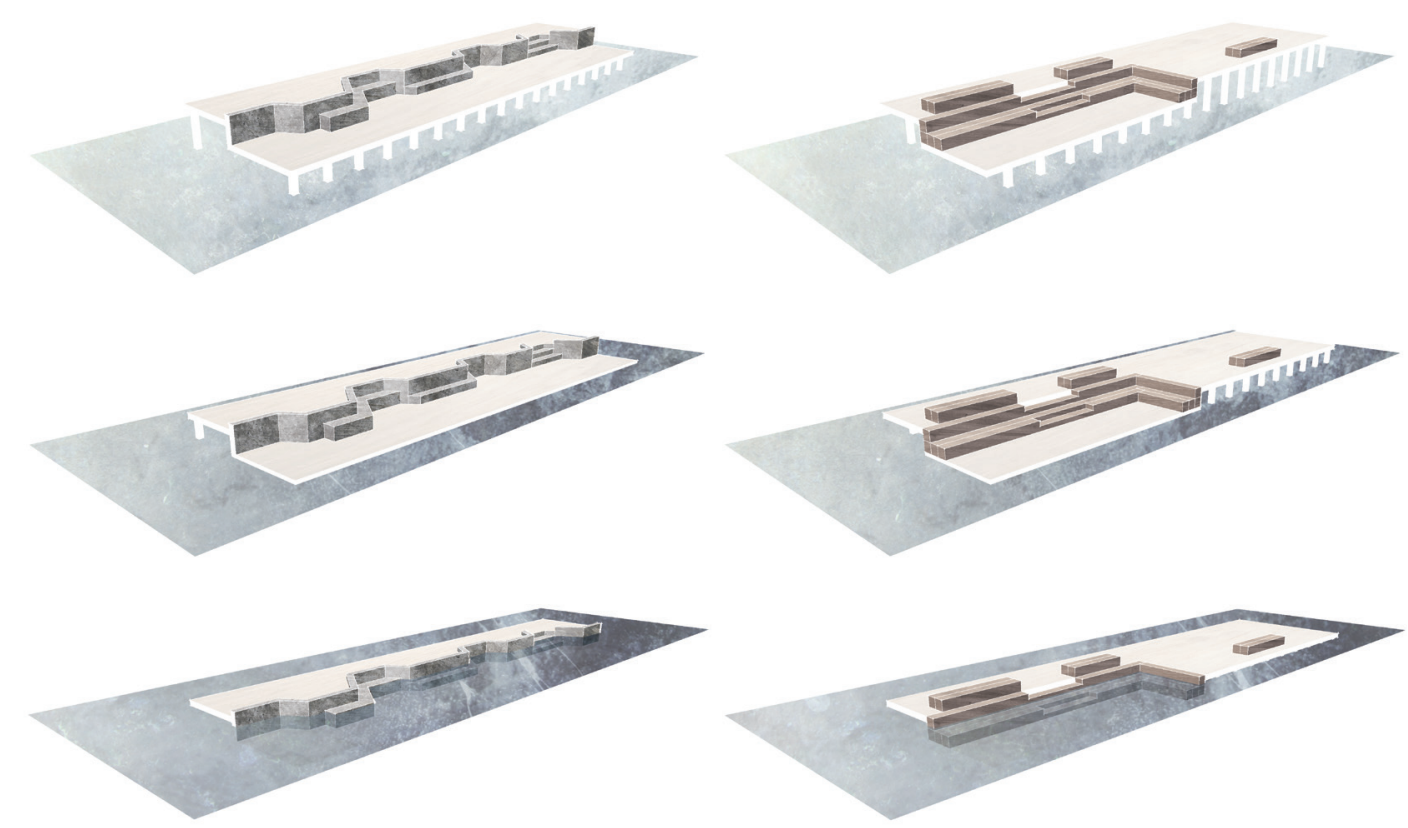

Study of different public seating options on the boardwalks and how these might interact with changing water levels. This iterative study revealed how using vertical levels and sacrificial spaces creates a better relationship between visitor and site. 


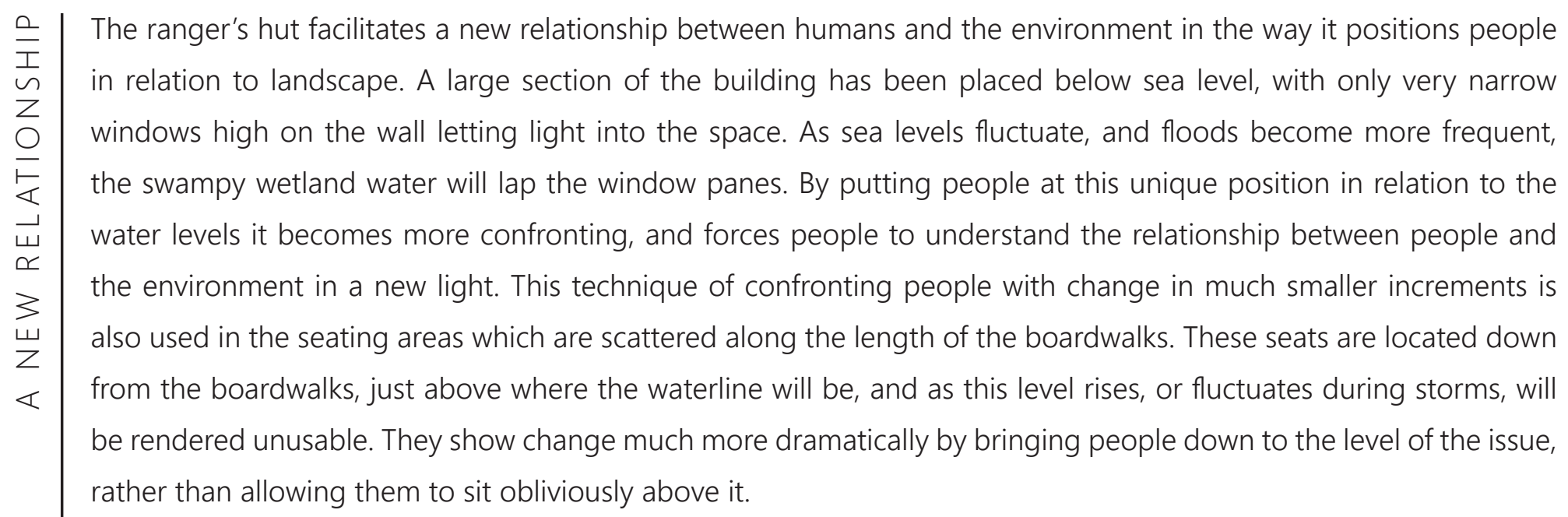




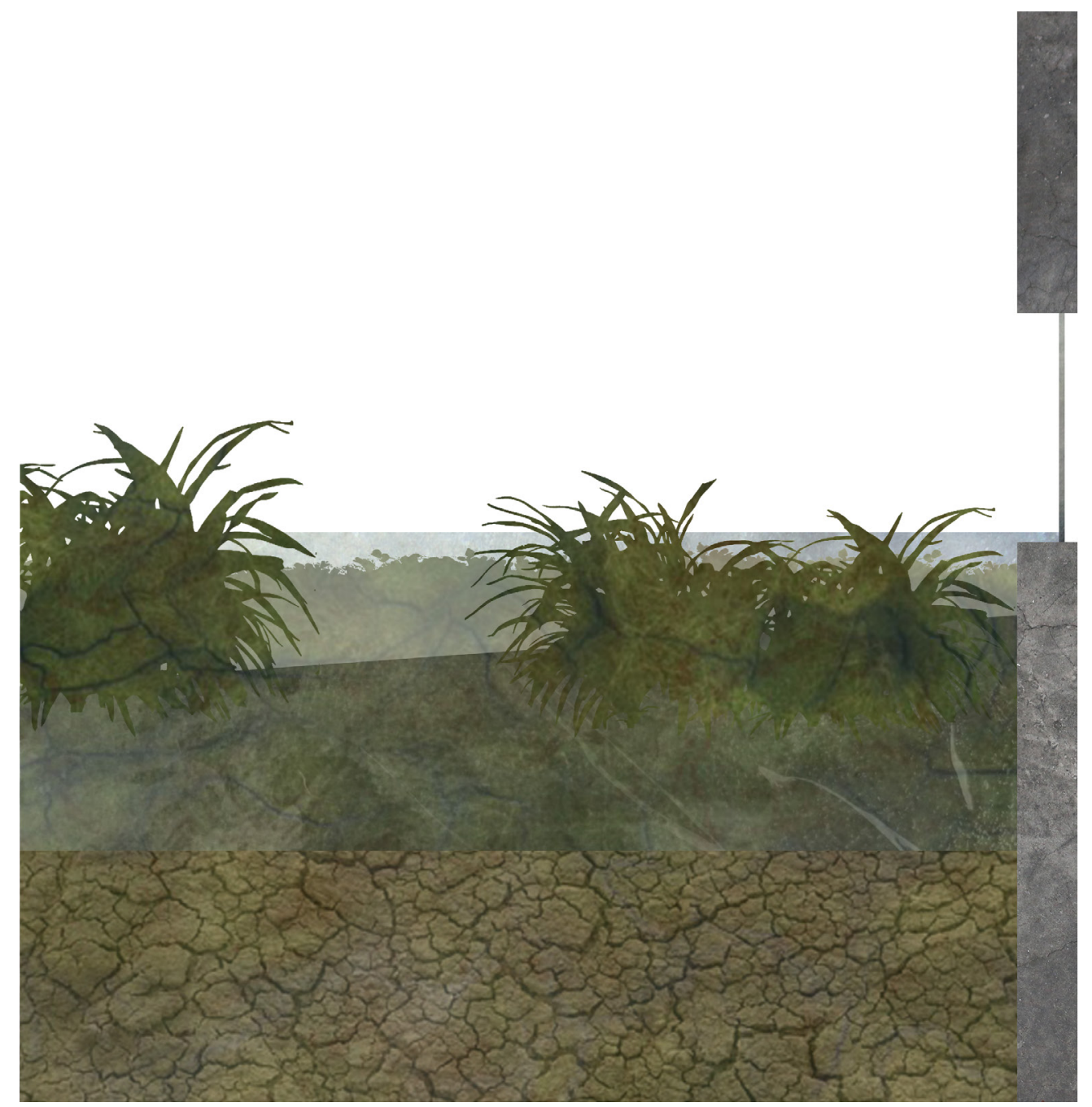

Section study of

relationship between

visitor and site.

The high windows in the basement level allow for visitors to be at eye level with the wetland system, encouraging a stronger relationship between visitor and site. 


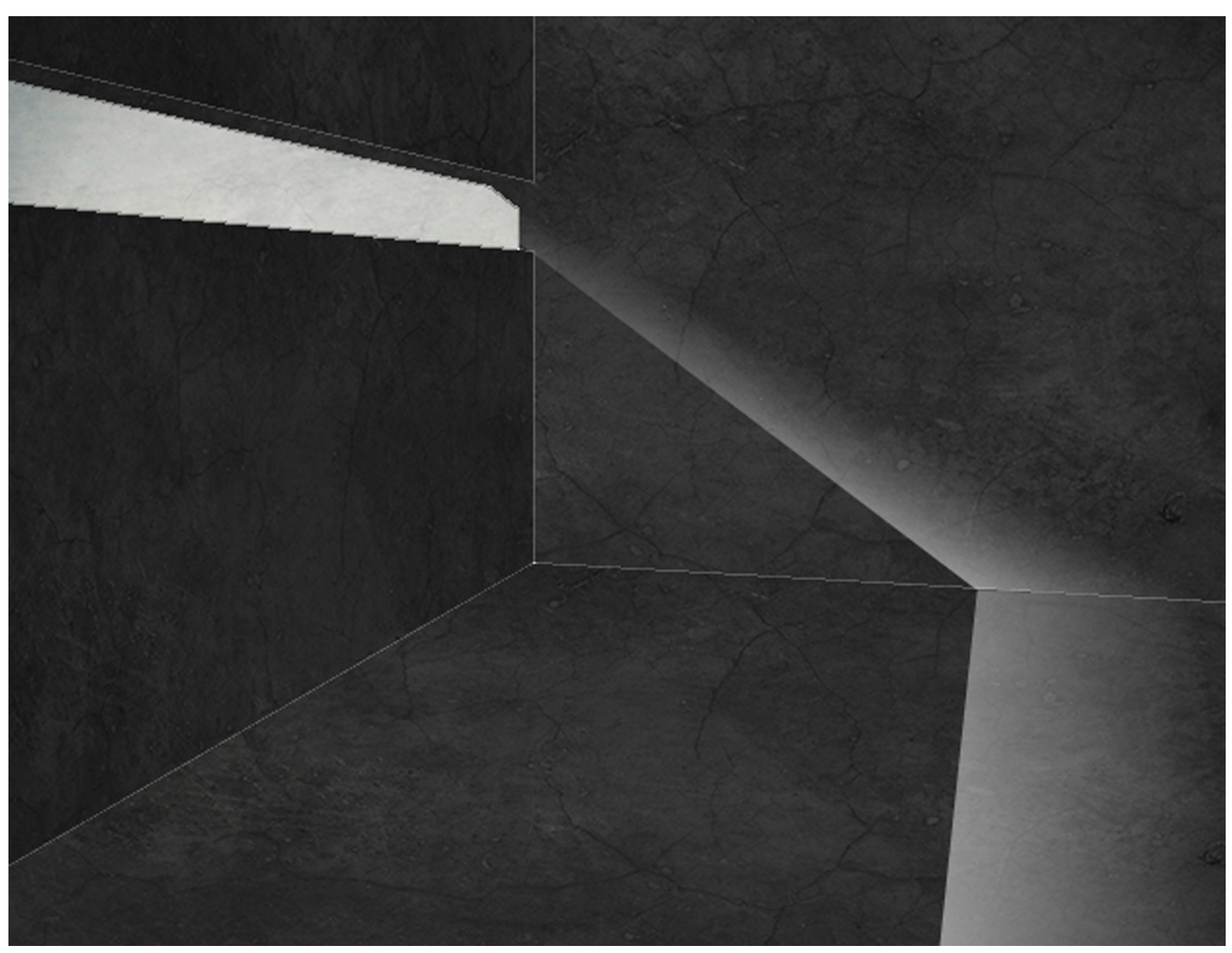

Light qualities in

basement.

The thin windows in the basement allow for small beams of light to enter the dark space, revealing the space in a different manner to the bright open spaces above. 


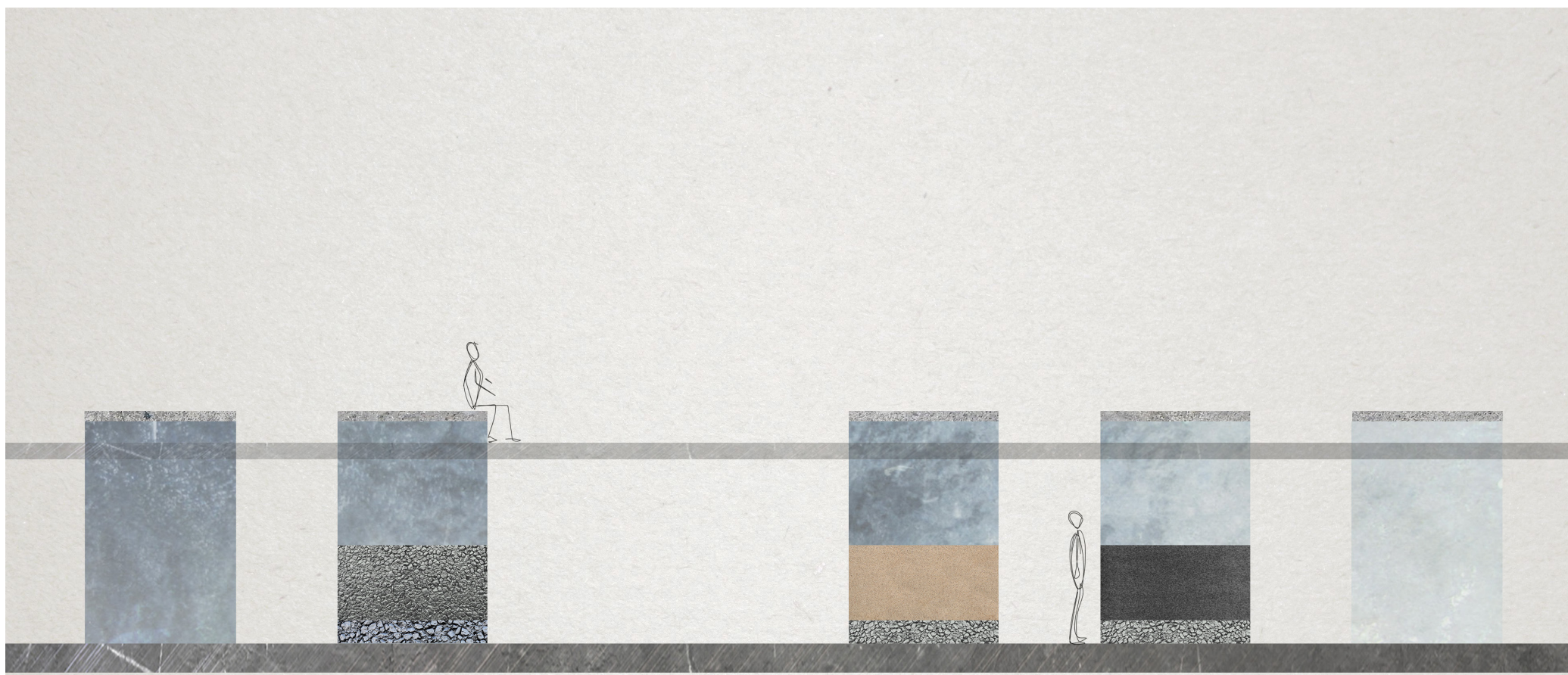

FIGURE 63

Water treatment system.

Clear tanks protrude through the pavilion level. This allows people to view them from the basement level and use them as seating at the pavilion level.

Diagram of how system works.

$1 \quad$ Untreated water 2 Backwash valves

3 Upflow gravel roughing filter
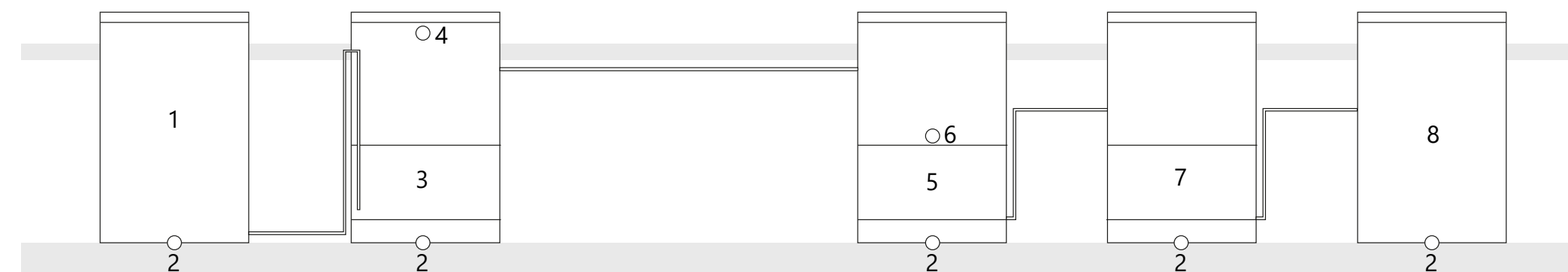

4

Float valve

Slow/bio sand filter

6 Harrowing valve

7 Charcoal/biochar filter 
The water purification takes place using a natural biochar water treatment system which is situated in the basement area of the building and protrudes through to the open pavilion level. Biochar is defined as "a solid material obtained from the thermochemical conversion of biomass in an oxygen-limited environment". ${ }^{38}$ It is essentially a charcoal like substance that is most commonly used as an additive to soil due to its ability to aid in water and nutrient retention. However, it also has the ability to be used as a part of a water purification system. ${ }^{39}$ The wetland system will provide a certain level of purification in its ability to remove pollutants from the water, while further purification will allow it to be used as the drinking water for the building. Using a series of five large transparent water tanks, the process becomes visible to visitors in the space and is confronting in the way it shows the change in water clarity as it goes through the process. The system sees water being pumped in from the wetlands, filtered through gravel, sand and charcoal (biochar) before being safe to drink and pumped through to the home and public drinking stations.

${ }^{38}$ Ok, Yong Sik, Sophie Uchimiya, Scott Chang and Nanthi Bolan. Biochar: Production, Characterization and Applications. CRC Press, 2015. 39 "Profile: Using biochar for water filtration in rural South East Asia." International Biochar Initiative. Oct. 2012. http://www.biochar-international. org/profile/water_filtration 
Solar

The roof of the building is lined with solar panels to bring down the carbon footprint of the building. The expansive roof space enables 102 270W Mitsubishi Electric Monocrystalline panels to be installed. It is suggested that 20 of these panels is sufficient to cover the entire electricity needs of the standard Wellington home, based on an average standard monthly usage of $680 \mathrm{kWh} .{ }^{40}$ This ensures that there will be plenty of energy to power the building, as well as allowing for any excess to be sold back to the grid. Any profits from this power sale will go back into the park, and will be used for community projects and events within the park. The solar panels will be fixed to an adjustable tilt system which is controlled from within the building. This enables the angle at which they sit to be changed as necessary throughout the year, sitting mostly at a standard position of 41 degrees as recommended for the Wellington area. ${ }^{41}$ This implementation is however based on the assumption that multiplying the system recommended as 20 panels would be feasible for the project. 


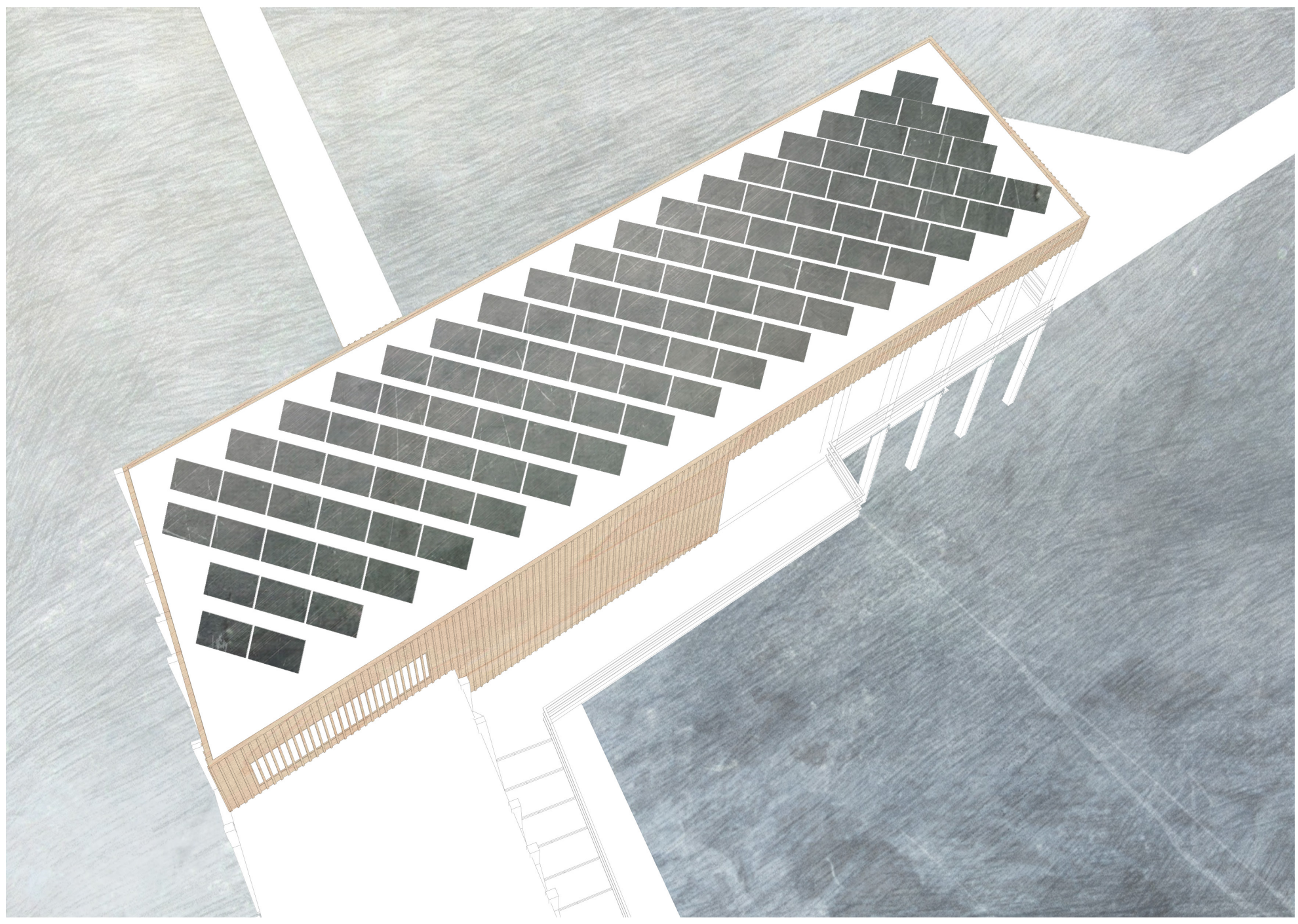

FIGURE 64

Solar energy harvesting.

102 solar panels lining the roof of the living wing of the building. They are positioned north facing to ensure maximum solar gain. 


\section{CONCLUSION}

This thesis explores how architecture might facilitate public education about the relationship between coastal inhabitation and delicate landscapes. The research focuses on the Kapiti Coast, looking at how the Raumati sea wall, designed to protect the homes behind it, has accelerated coastal erosion at the northern end of Queen Elizabeth Park. The scheme looks at how the reinstatement of a wetland system and implementation of a ranger's hut in can be used to encourage a better understanding of the impact of human inhabitation on coastal environments.

The design process explored the opportunities that were opened by the erosion, encouraging the section of the beach that has been most significantly decayed to erode further, becoming the outlet point for the wetland system. The location of the wetland subsequently cut off access from Raumati to the park, opening another opportunity to create a new gateway to the park. The boardwalk system leads visitors from the existing Raumati entranceways, over the wetlands, to a central axis point where the ranger's hut lies, before leading through to the rest of the park. 
Sitting both above and below the boardwalk system, with an open pavilion space between; the ranger's hut acts as home, embassy and church. It brings visitors and members of the community together, encouraging them to engage with the space.

The project recognises the importance of people in learning, putting an eccentric family at the centre of the design and using abstract imagery to suggest the fictional nature of the narrative. The design revolves around people, with flexible floor plans and a variety of spaces making it an ideal venue to host a range of different events and visitors. The project also acknowledges the role of the landscape in facilitating public learning, acting as a vessel from which the landscape can be understood. The design provides moments from which people can view the wetland and dune systems at eye level, from directly above or at an elevation.

The thesis uses architecture to facilitate public education about the relationship between coastal inhabitation and delicate landscapes by suggesting a built form which responds to and withstands changing landscapes, rather than trying to fight them change as sea walls do. It uses architecture as a venue and vessel, to host people and events and provide vantage points from which to observe change. The project, located at the end of the Raumati sea wall, explores an alternative solution to the desire for coastal living and the need to protect our delicate coastline, as well as educating the public on the relationship between the two. 


\section{THE PROCESS}

Chronological documentation detailing how design decisions led the research. 


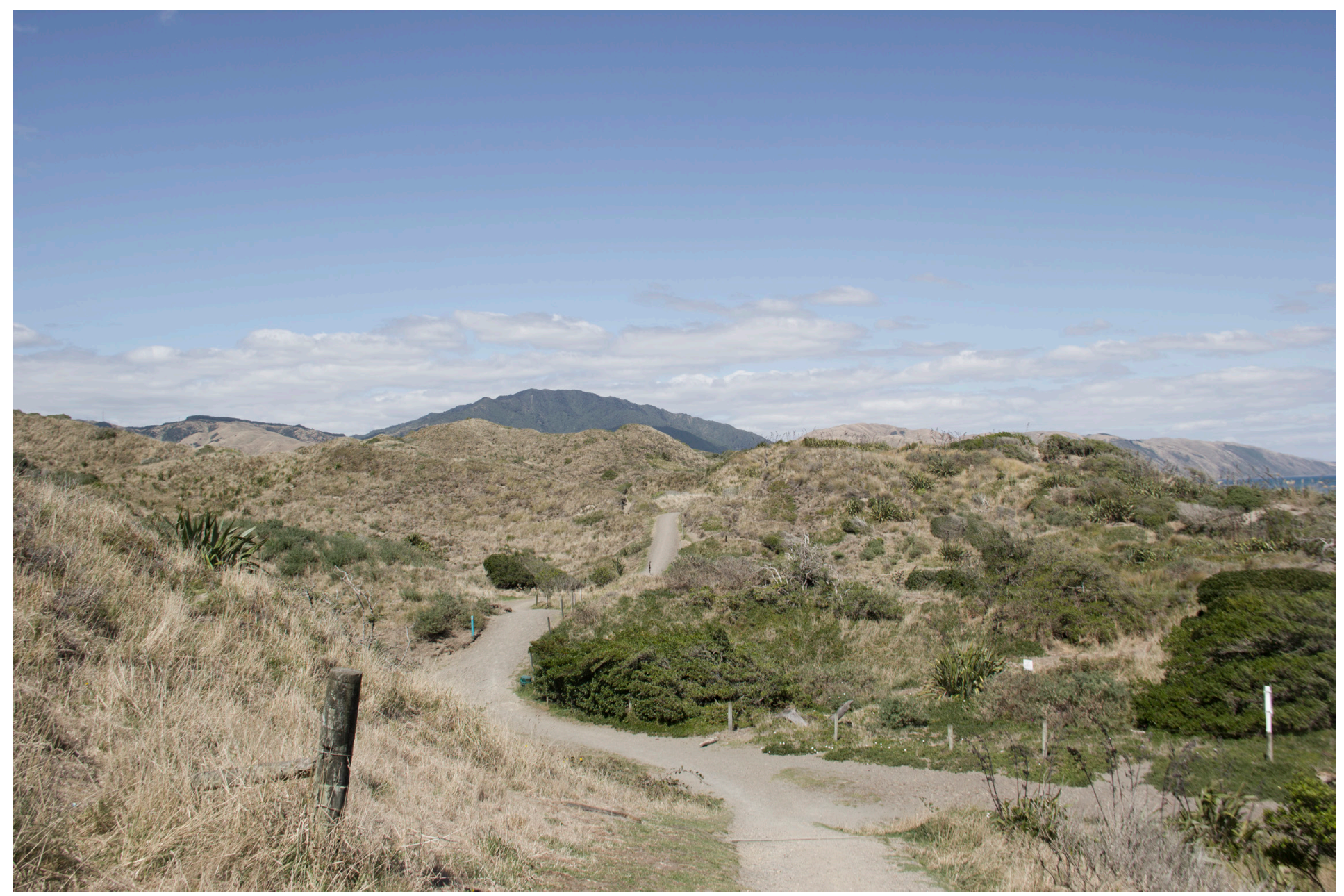

Dunes at Queen Elizabeth Park.

Image from site visit showing walkways running through dunes. 

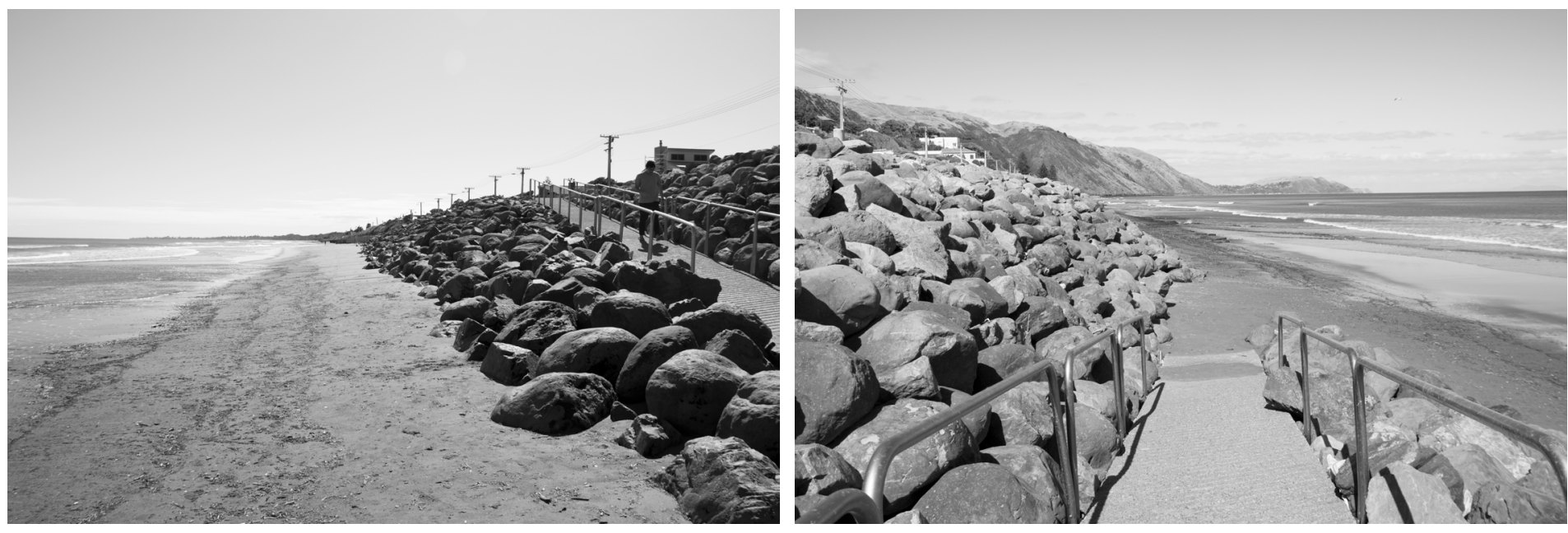

FIGURE 66
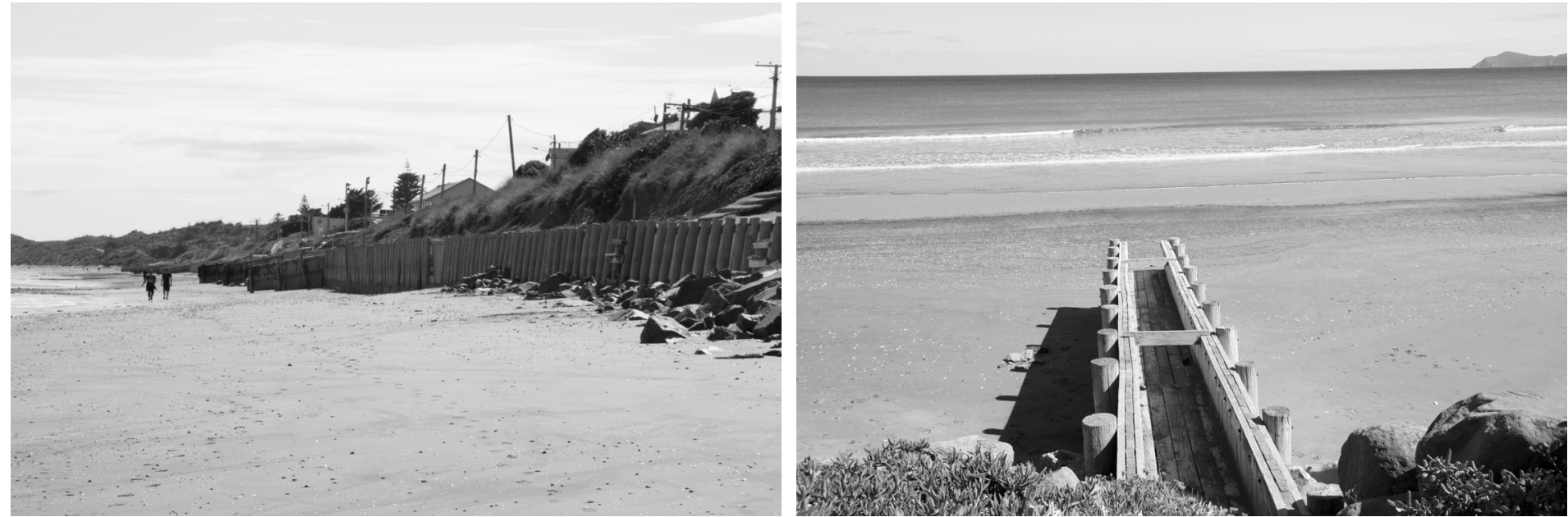

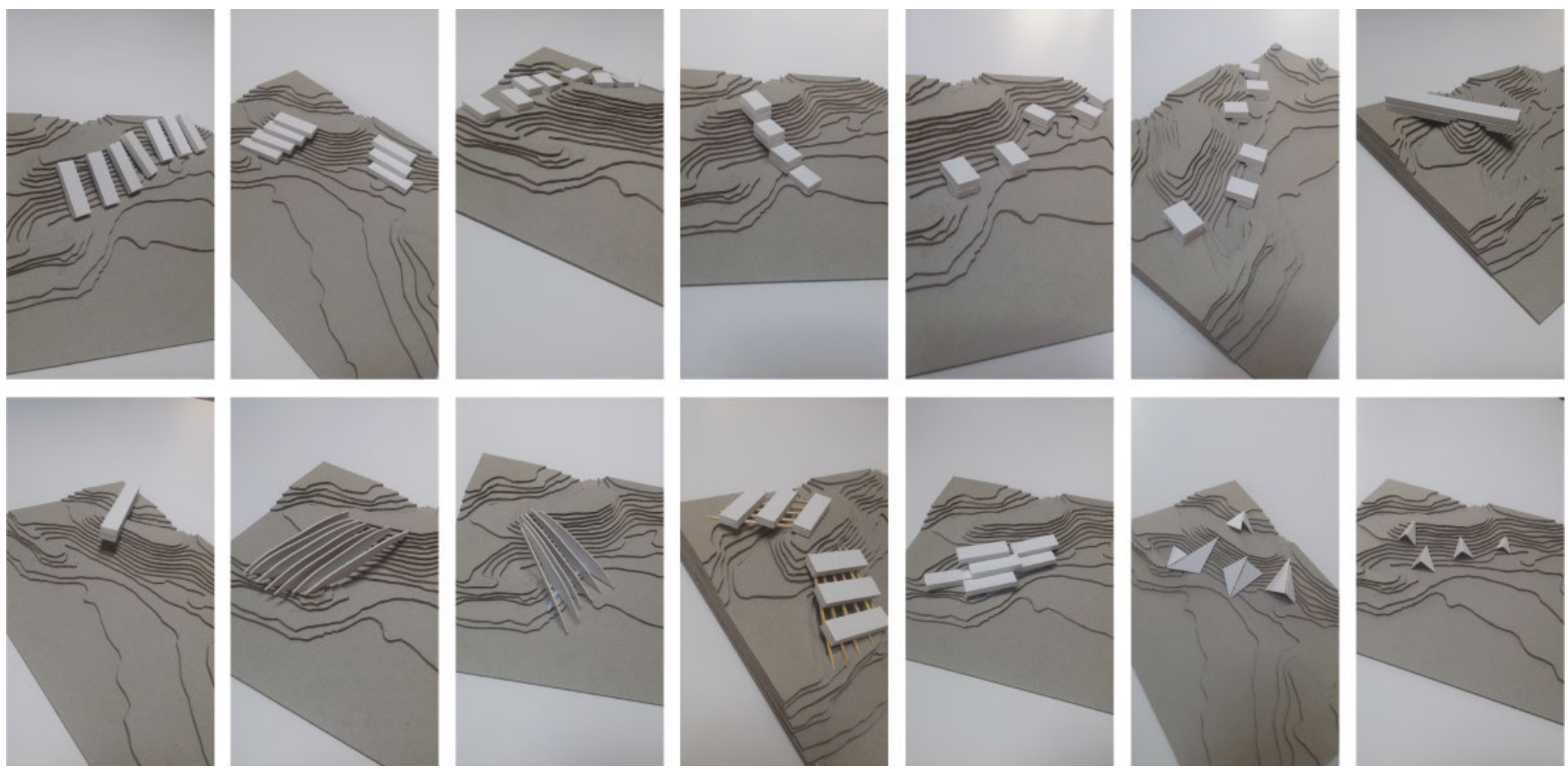

Massing models.

Iterative models exploring massing on the site.

Massing seemed too

fragmented and didn't

look at the wider impact

on site. 

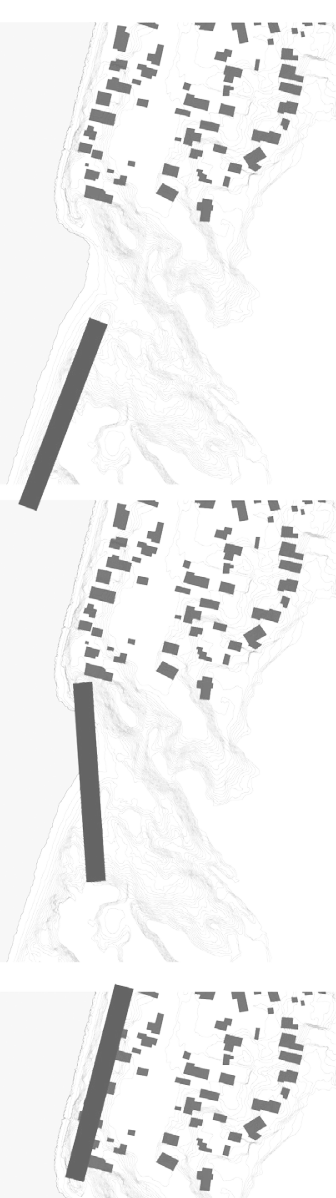
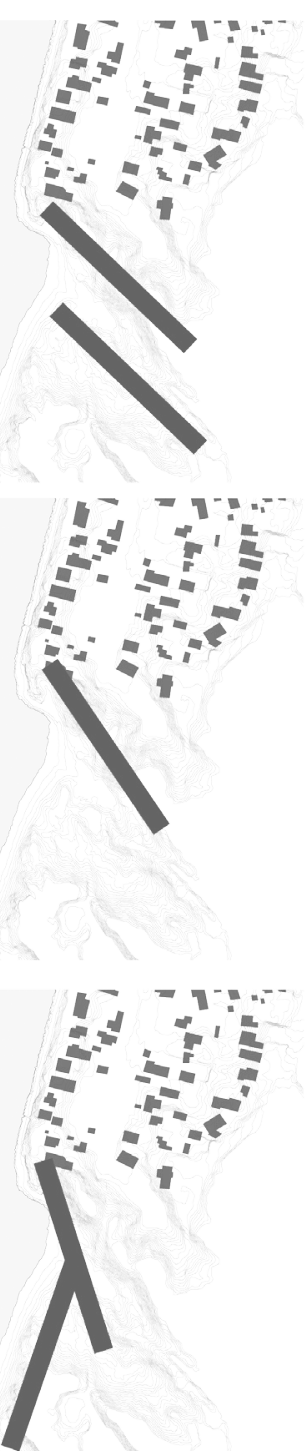
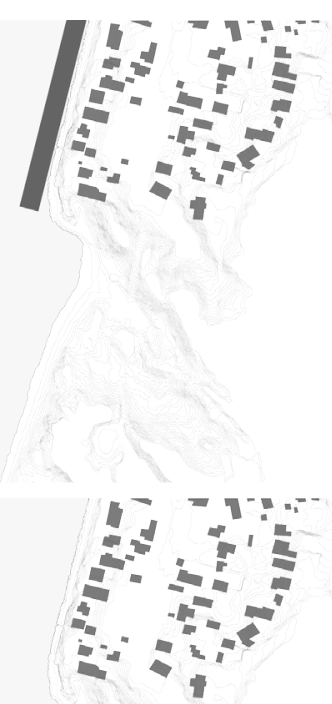

I

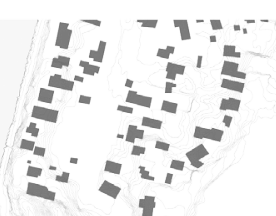

1
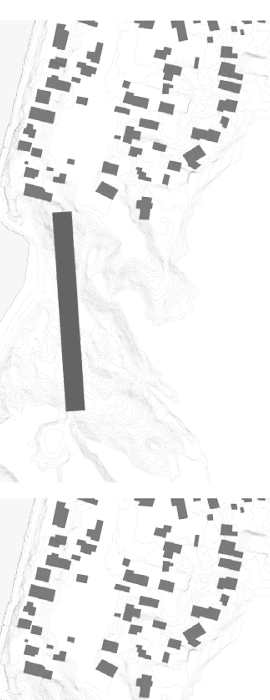

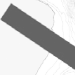
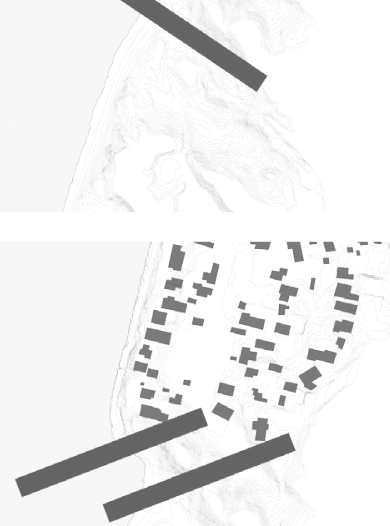

FIGURE 68

Iterations of large mass

on site.

Iterative images looking at how a large building might sit in relation to site. Mass however is far too large in regard to existing urban scale. 


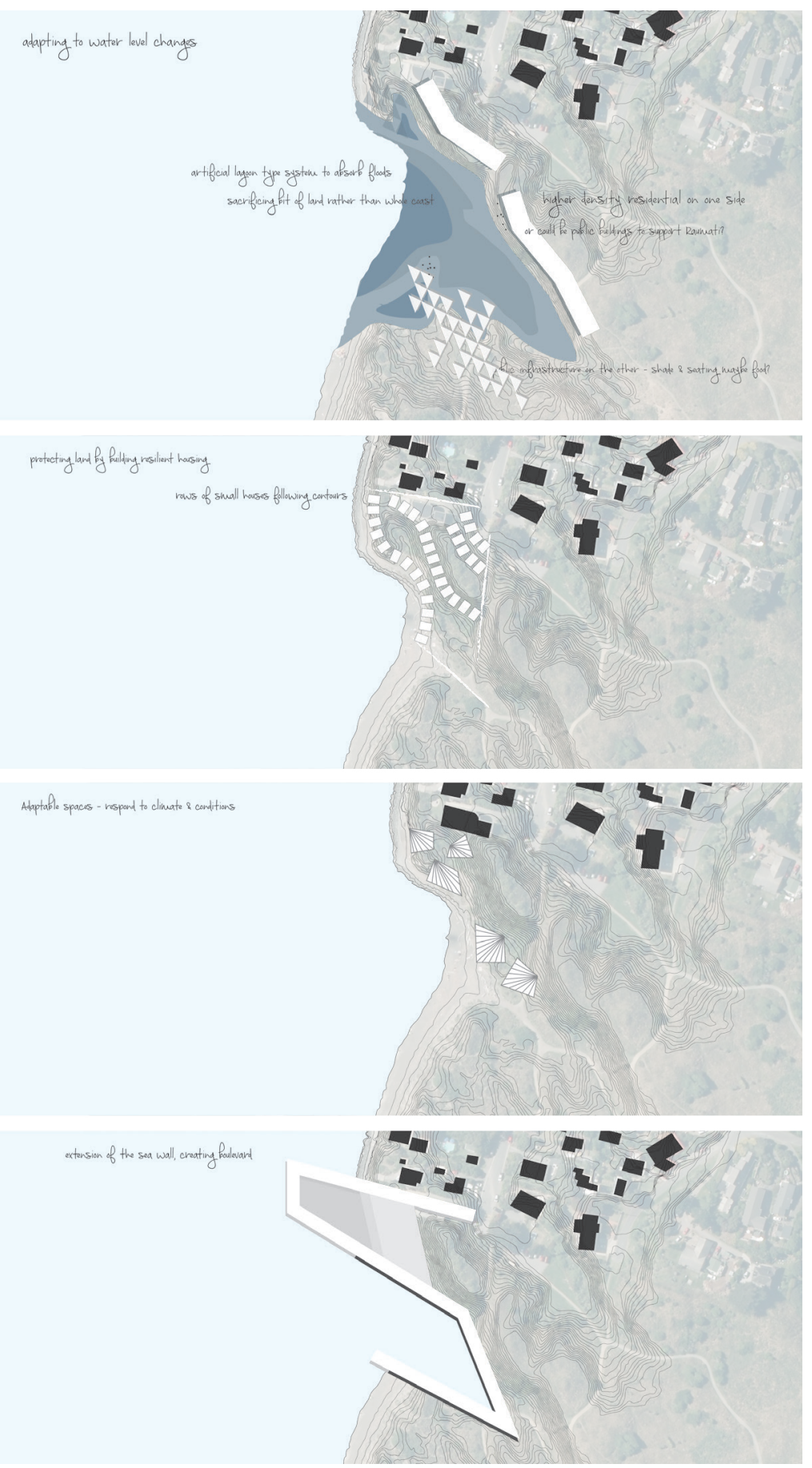

FIGURE 69

Adapting precedents to site.

Looking at precedents and analysing how similar schemes might work within the site. First look at how bringing water into the site might have a positive impact. 


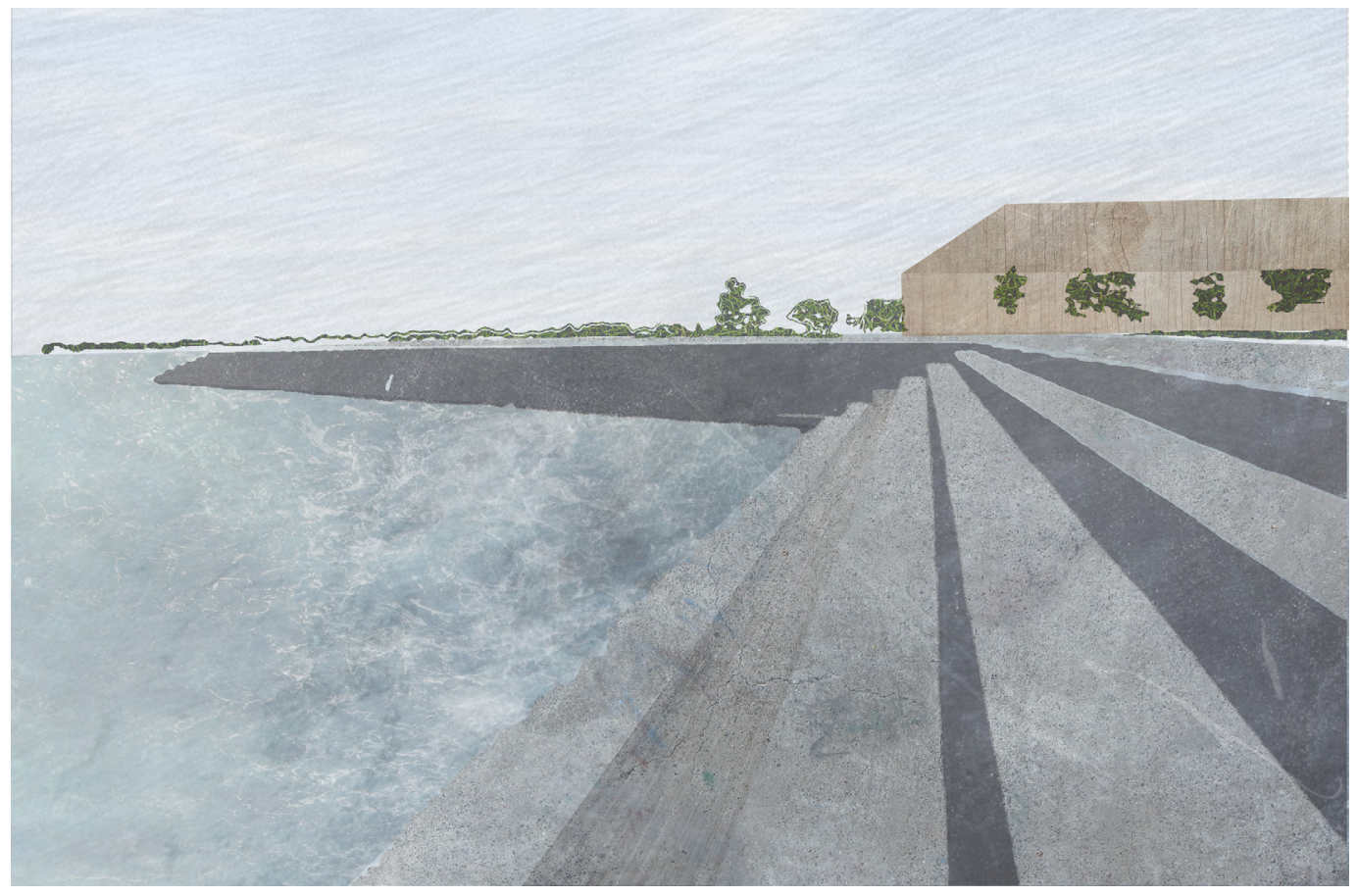

FIGURE 70

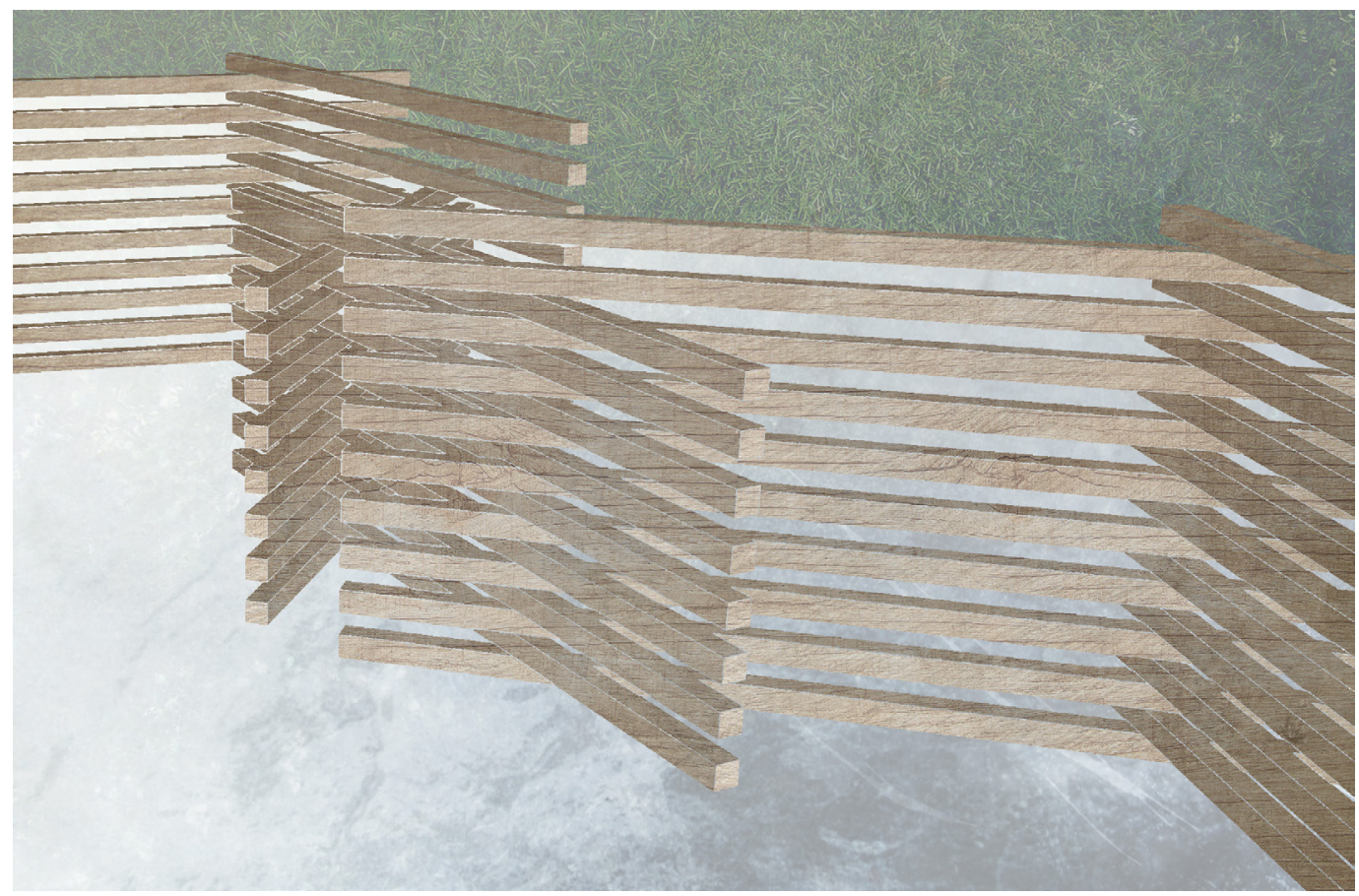

Fragmented sea walls.

Study of how a sea wall might be softened. As a staircase, it allows people to come closer to the water, softening vertical divide. The second perforated wall would not stop the land sitting behind from decaying. 


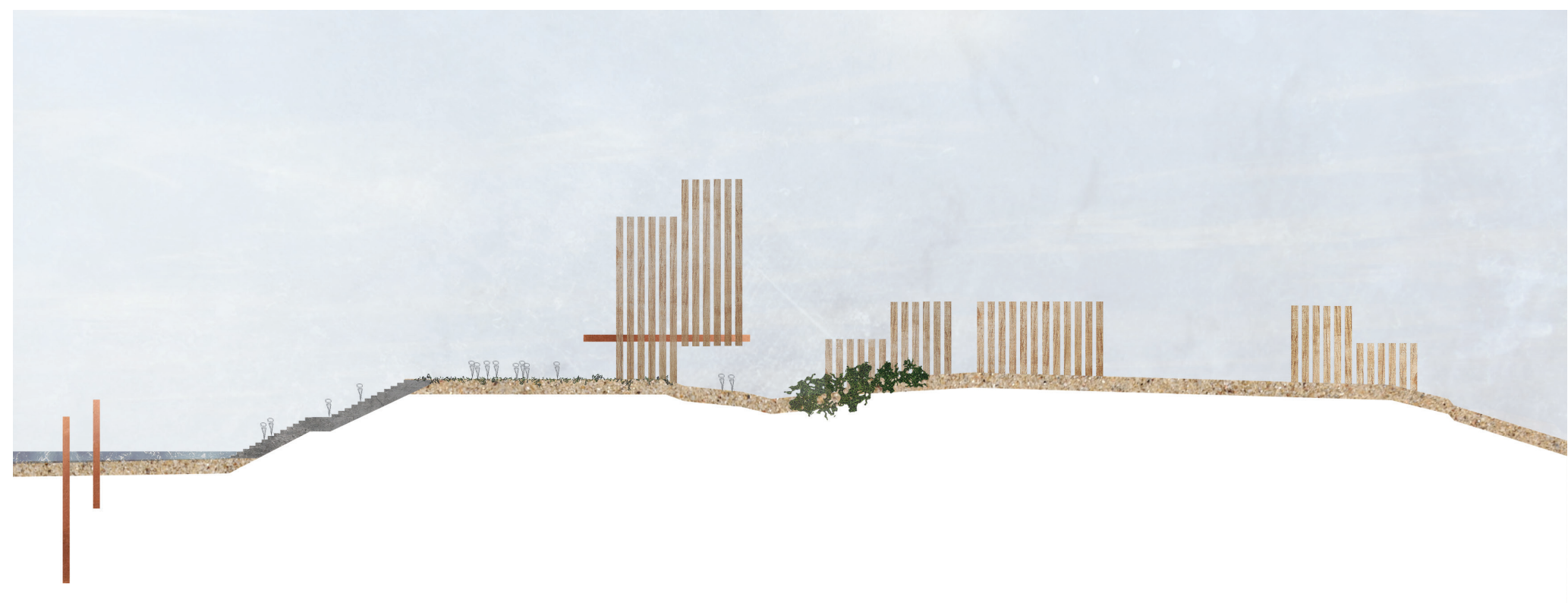

FIGURE 71

Section study replacing sea wall with stairs.

Looks at how setting back and replacing the existing sea wall with a staircase design might aid in bringing people closer to the coastline. However, this solution would still need a high level of maintenance as water would push below the structure. 


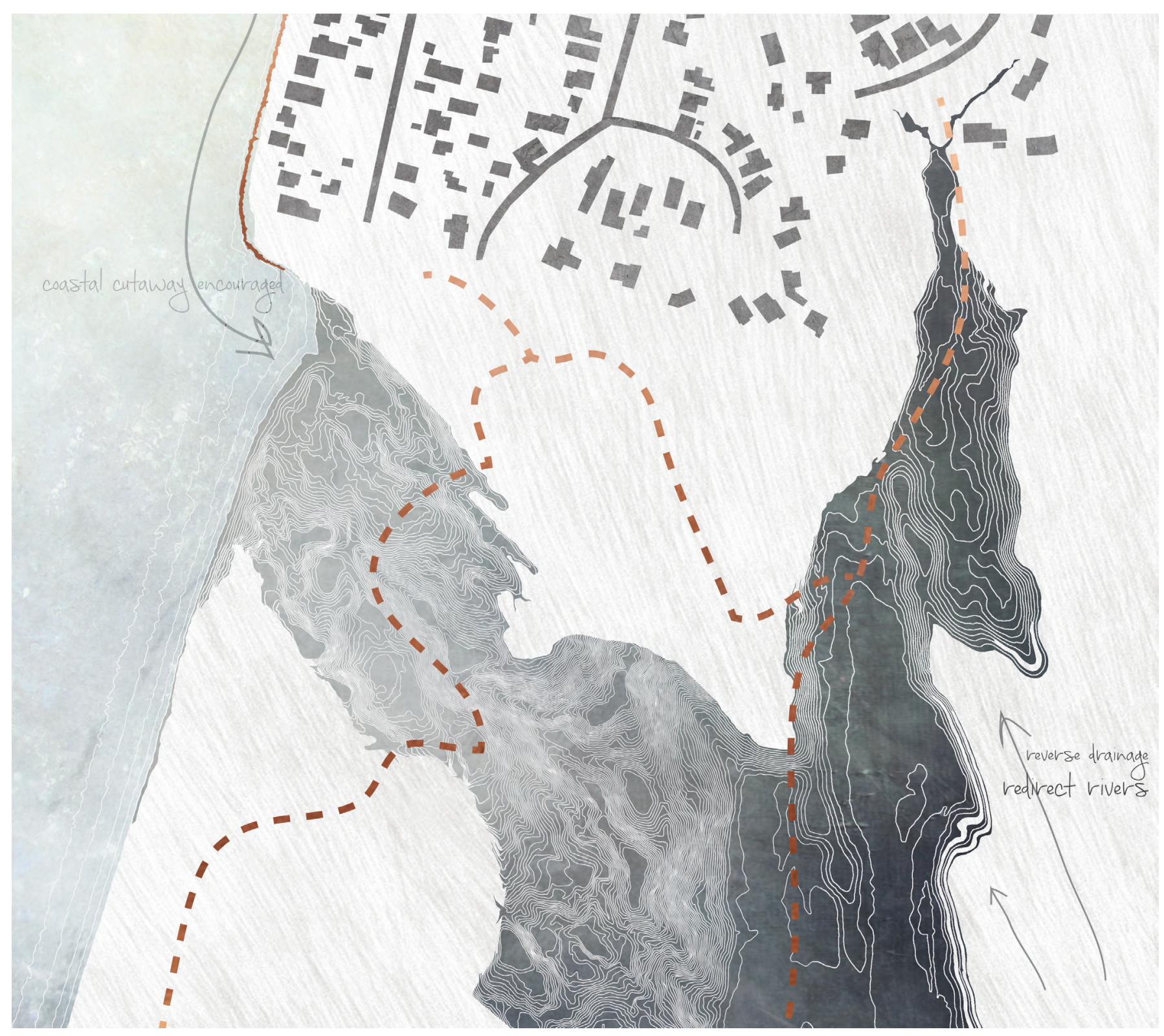

FIGURE 72

Implementation of wetlands.

Study of site explores how wetland system would interact with the sea wall decay and current walkways through site. Shows an opportunity to create new connection between Raumati and the park. 
Section of boardwalk over wetlands.

Sectioned image of site shows how design might sit on the edge of the dunes with the boardwalks over the wetlands.

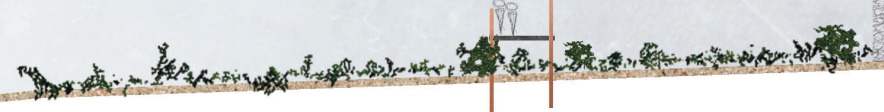


Massing of building uses with boardwalk system.

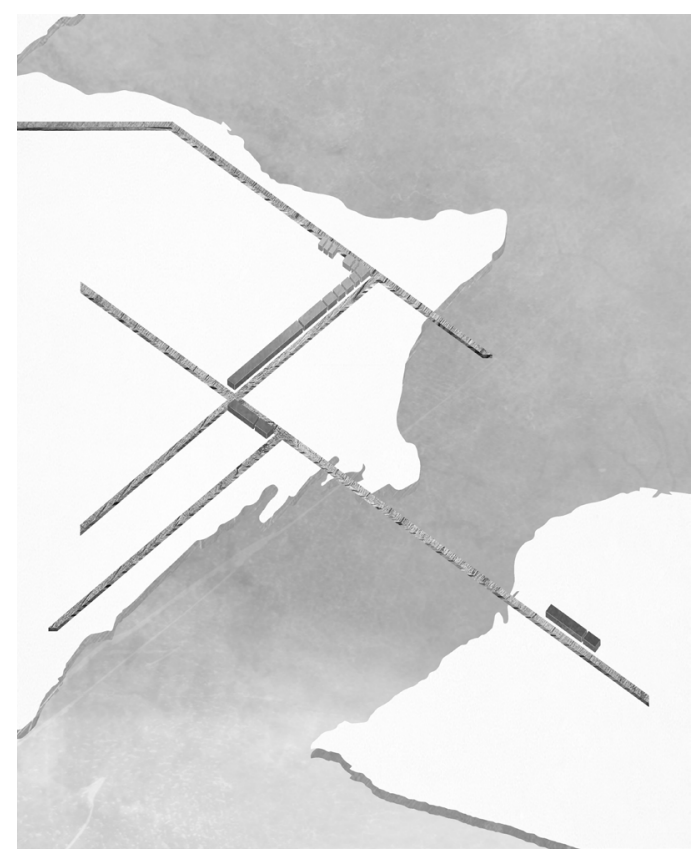

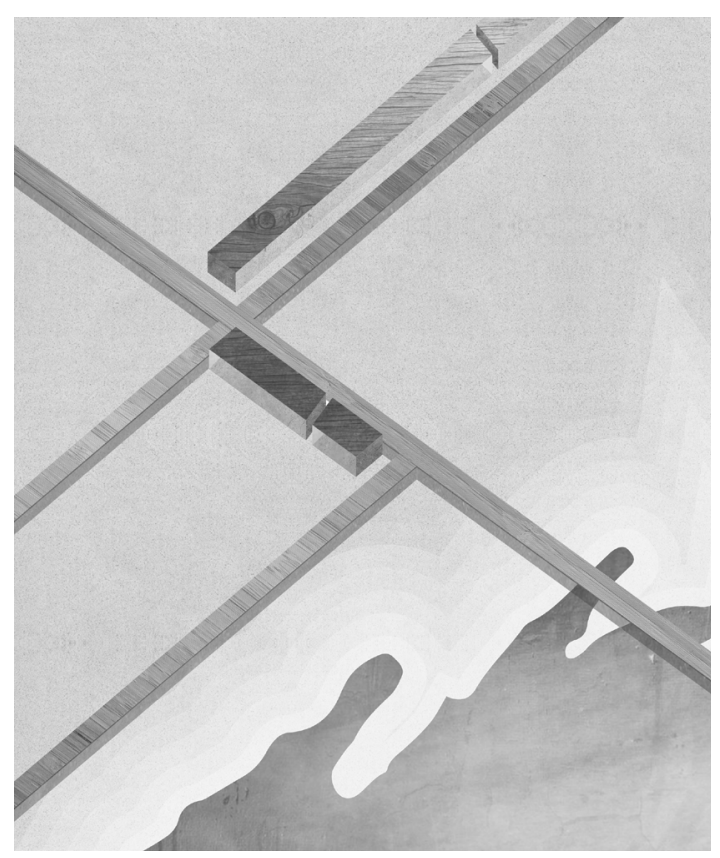

The study looks at the needs of the intended users as blocked forms in relation to the boardwalk system. Sitting on the dunes, there is still a disconnect between the built form and the wetland system. 
FIGURE 75

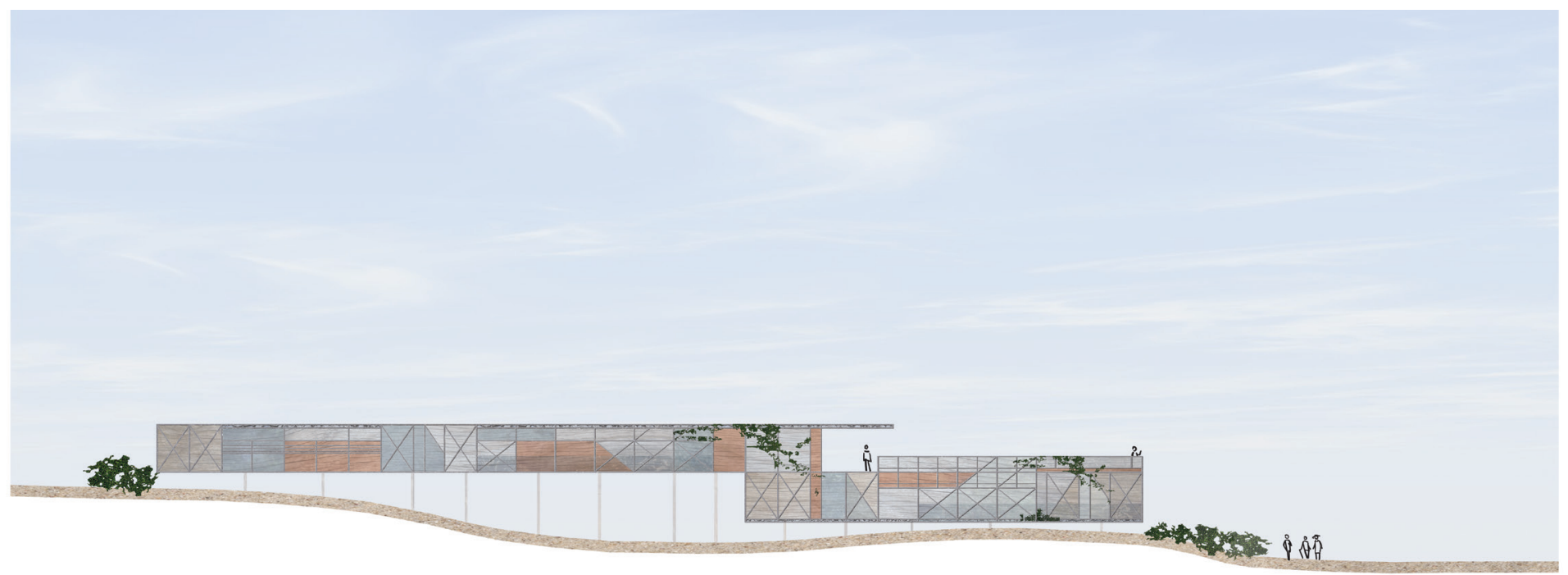

Elevation of concept.

The elevation shows the way in which the concept interacts with the dunes. However, it highlights how the typography of the dunes does not suit such a linear floor plan. 
FIGURE 76

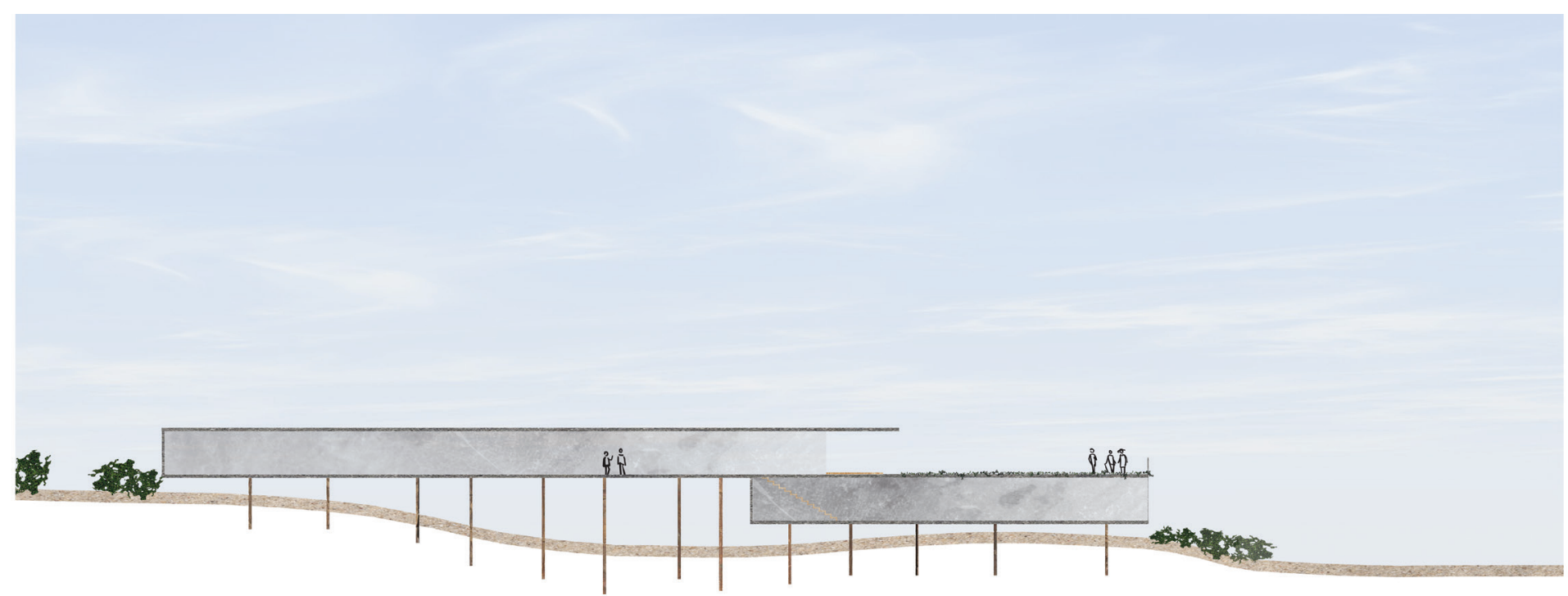

Section of concept.

The section shows the success of the concept in the way that the

boardwalk running

through the building and use of levels allows for a

blurred divide between

public and private spaces. 

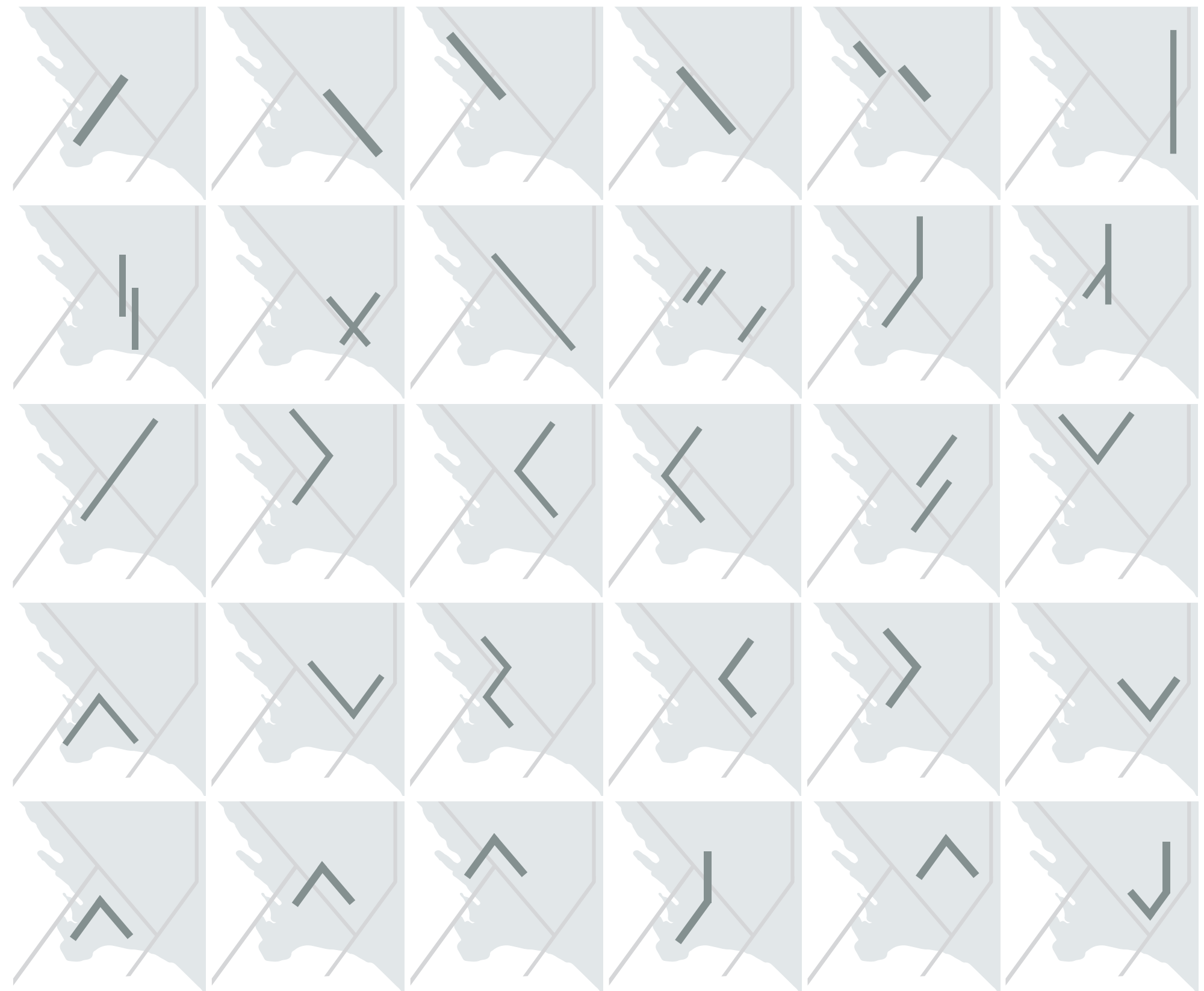

FIGURE 77

Orientation of $500 \mathrm{~m}^{2}$ masses.

Iterations of $500 \mathrm{~m}^{2}$

footprints sitting on the boardwalk system. The 'V' shape kept repeating due to the way it looked alongside the boardwalks. This shape also presents interesting spatial opportunities in the way it creates a courtyard type effect where one can look out from one side of the building over to the other. 
Deck positioning.

The iterative study shows options of how the deck shape might alter the relationship between the building and boardwalk system. However, this study was too focused on the geometry rather than creating a welcoming entrance with these options allowing visitors to bypass the building easily. 


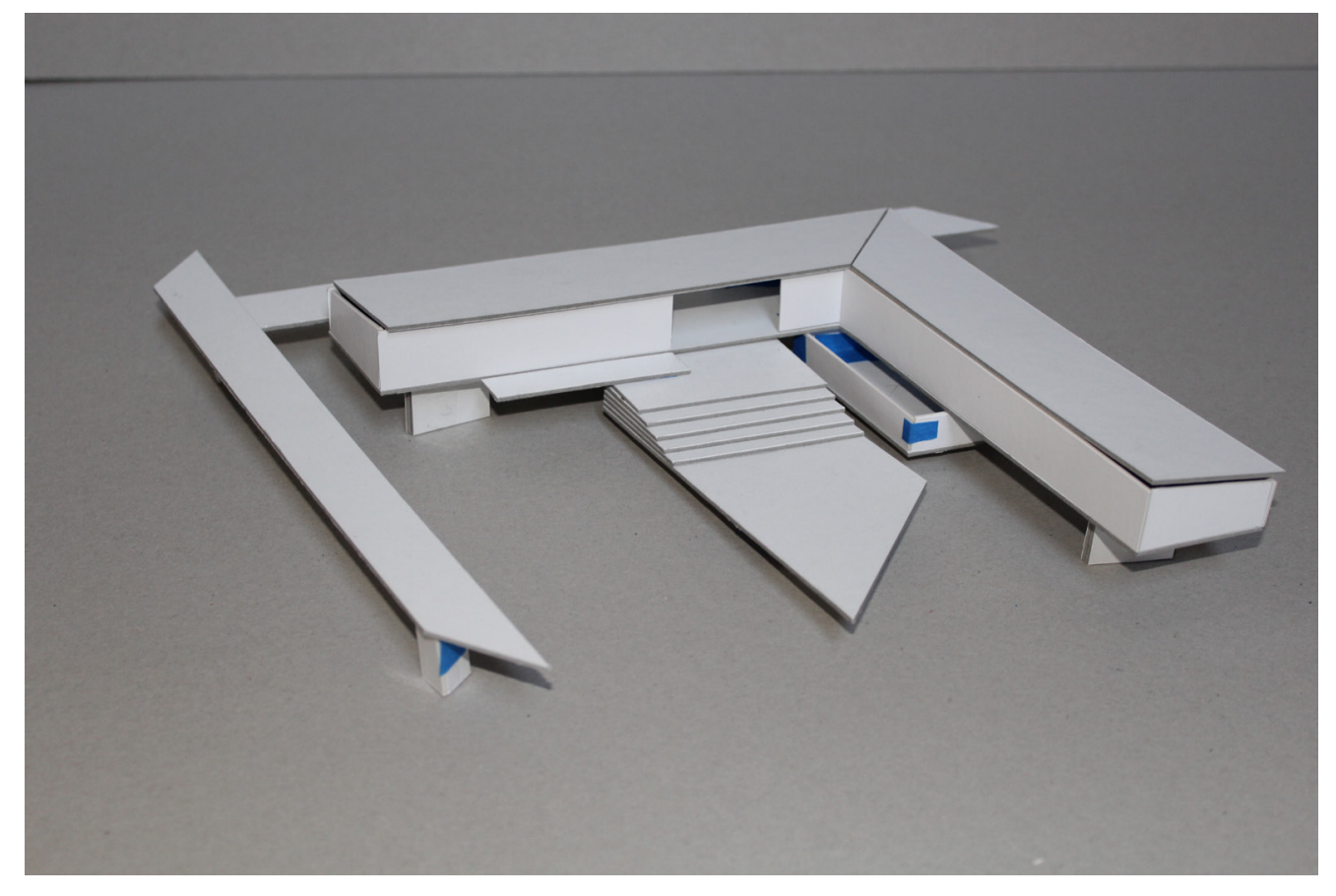

FIGURE 79

Cardboard model of concept.

Modelling the building in card emphasised the divide between the boardwalk system and the building. Having this separation did however provide a greater level of privacy for inhabitants of the space.

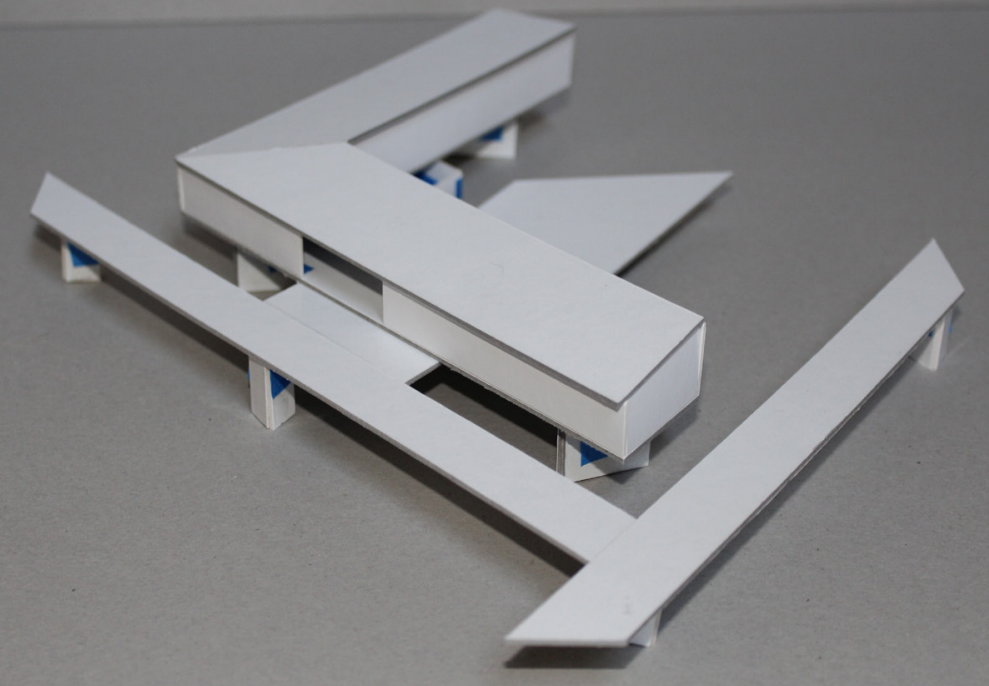




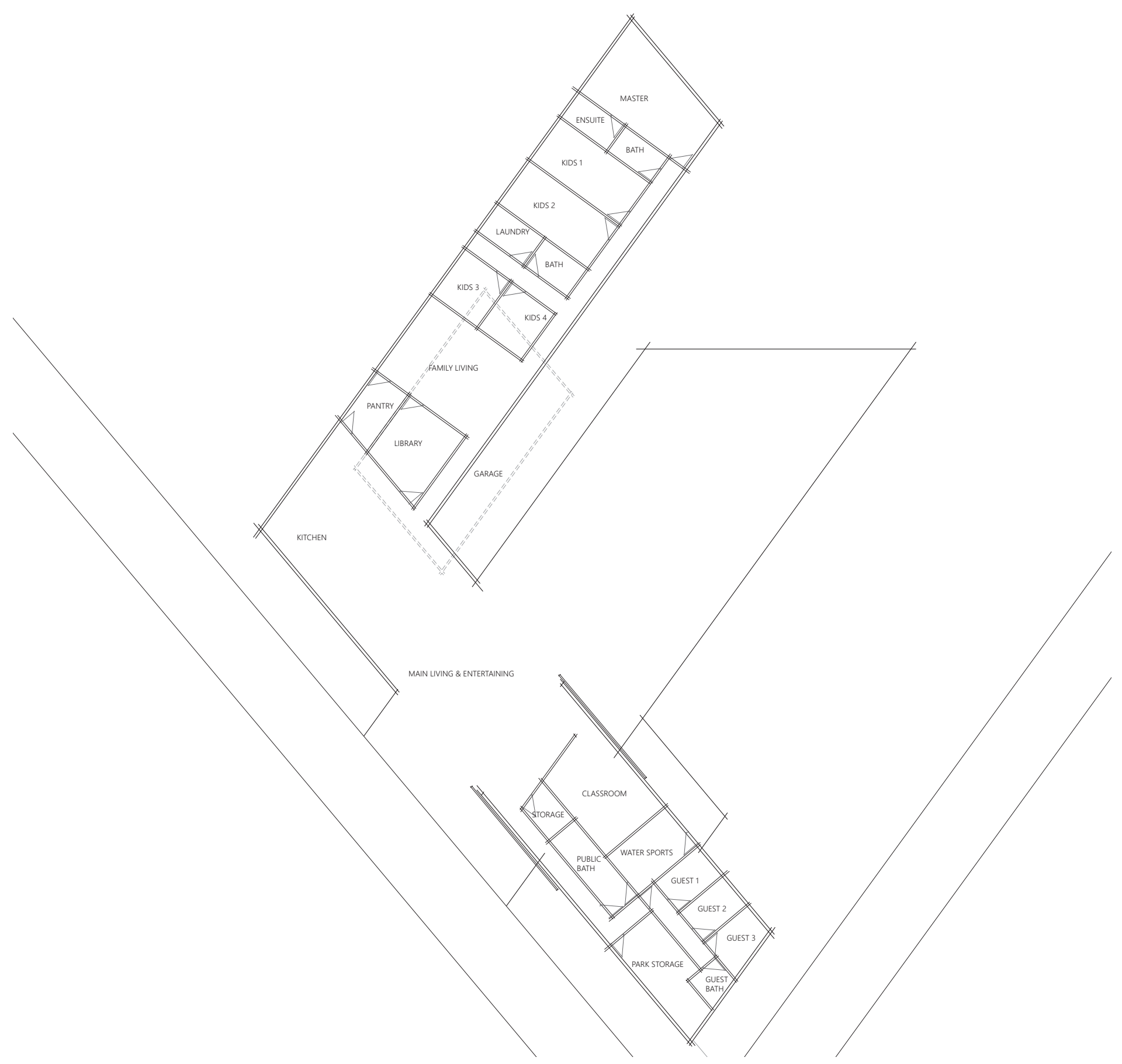

FIGURE 80

Concept Floor plans 1.

Having the building

positioned in this direction

is exclusive rather than

inclusive. It also positions

the main courtyard to the

morning sun, rather than

afternoon which is more

ideal for an entertaining

space. 


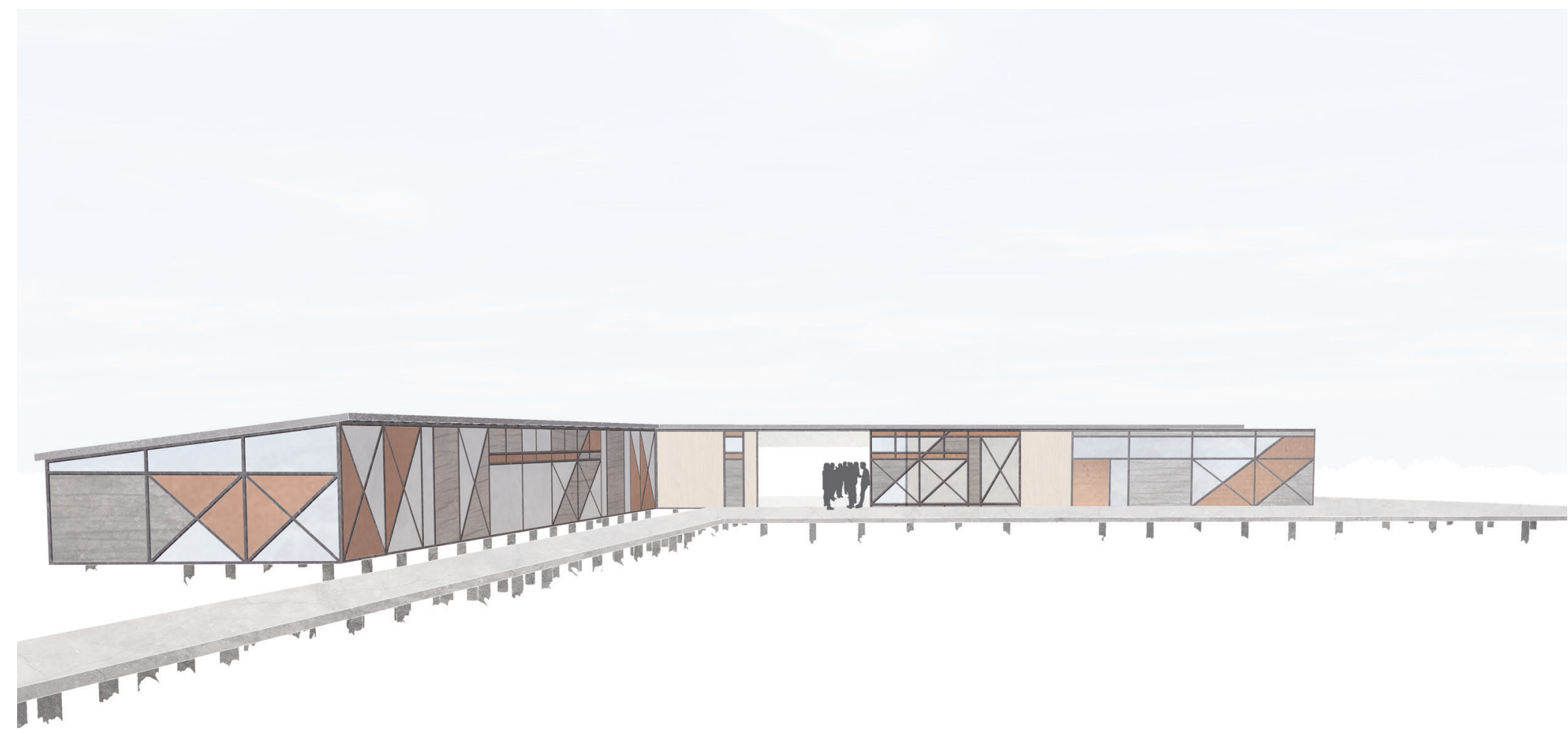

Perspective of concept on boardwalk.

The next concept saw a flip in the orientation of the ' $v$ ' shaped building. This made it a more inclusive space however the single level building highlighted the need for the building to interact more with the wetland system, rather than simply sitting above it. 


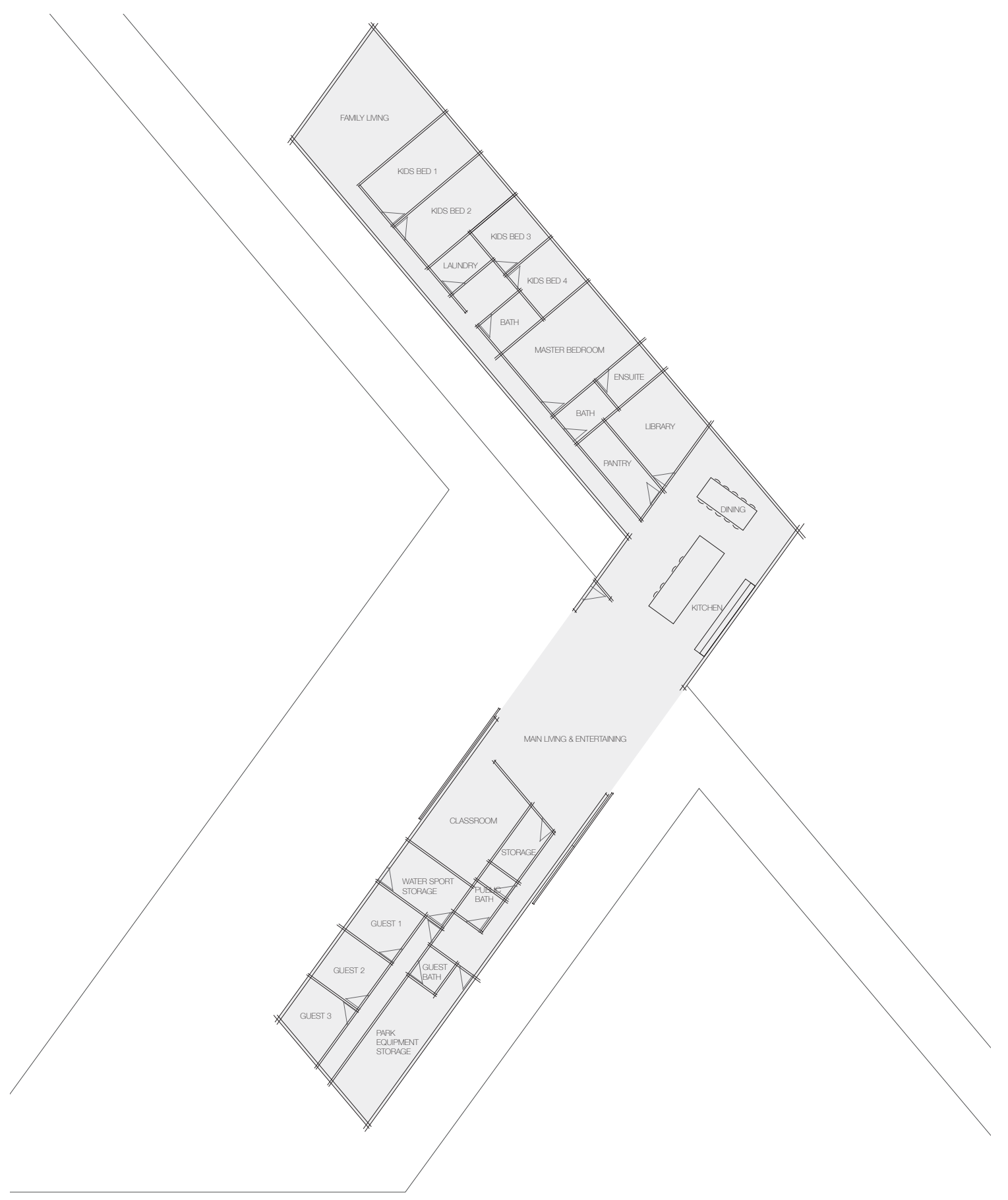

FIGURE 82

Concept floor plans 2.

The floor plan begins to explore how the building and the boardwalk can become one system. However, in this concept the level of privacy is compromised with the division between public and private spaces being only through a doorway. 

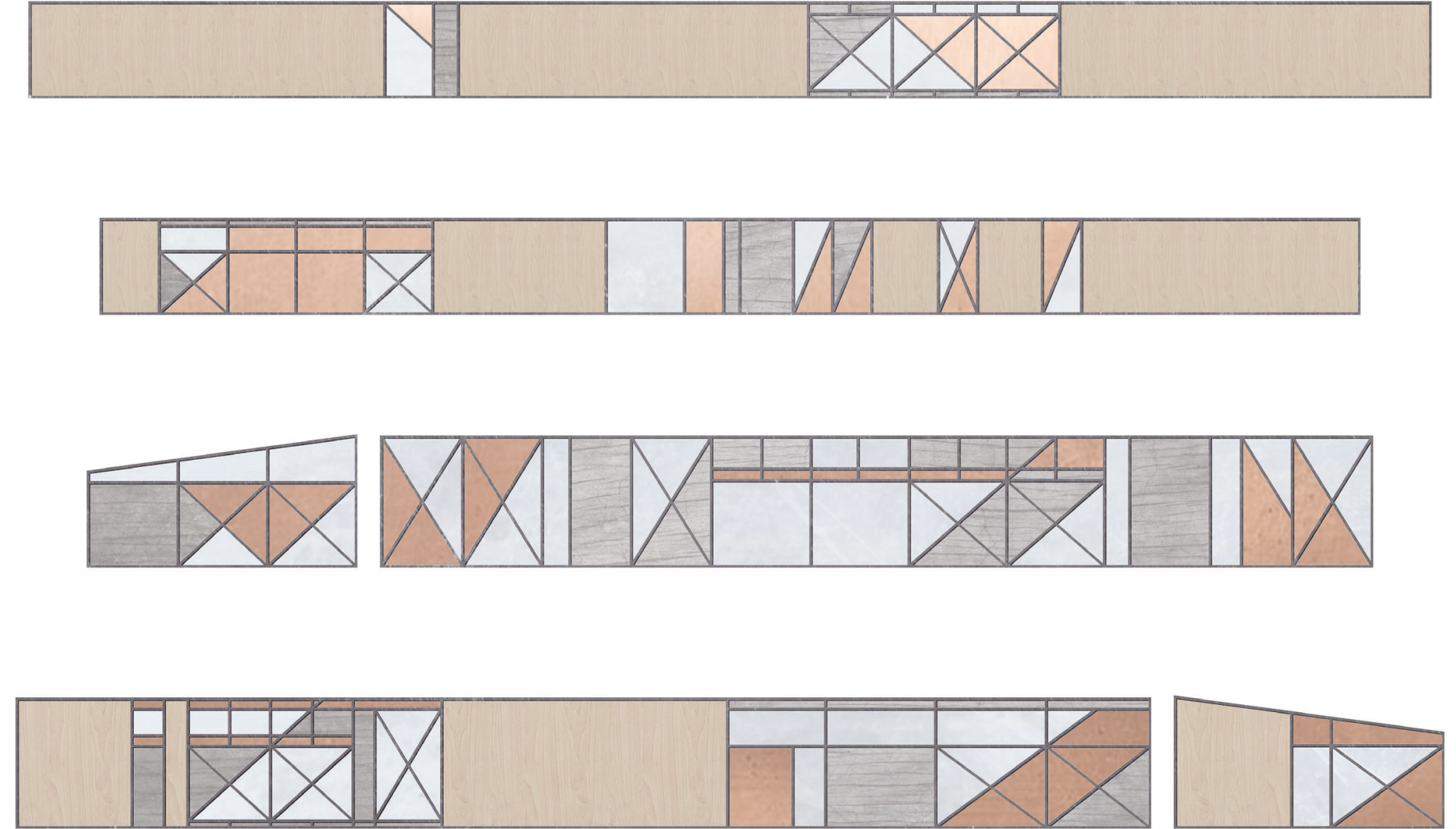

Concept façades.

The façades explore how windows and textures can be used to break up solid walls. This approach is interesting in that it uses non-traditional window shapes, however the transition between the textured panels and plain walls leaves the design looking overly fragmented. 


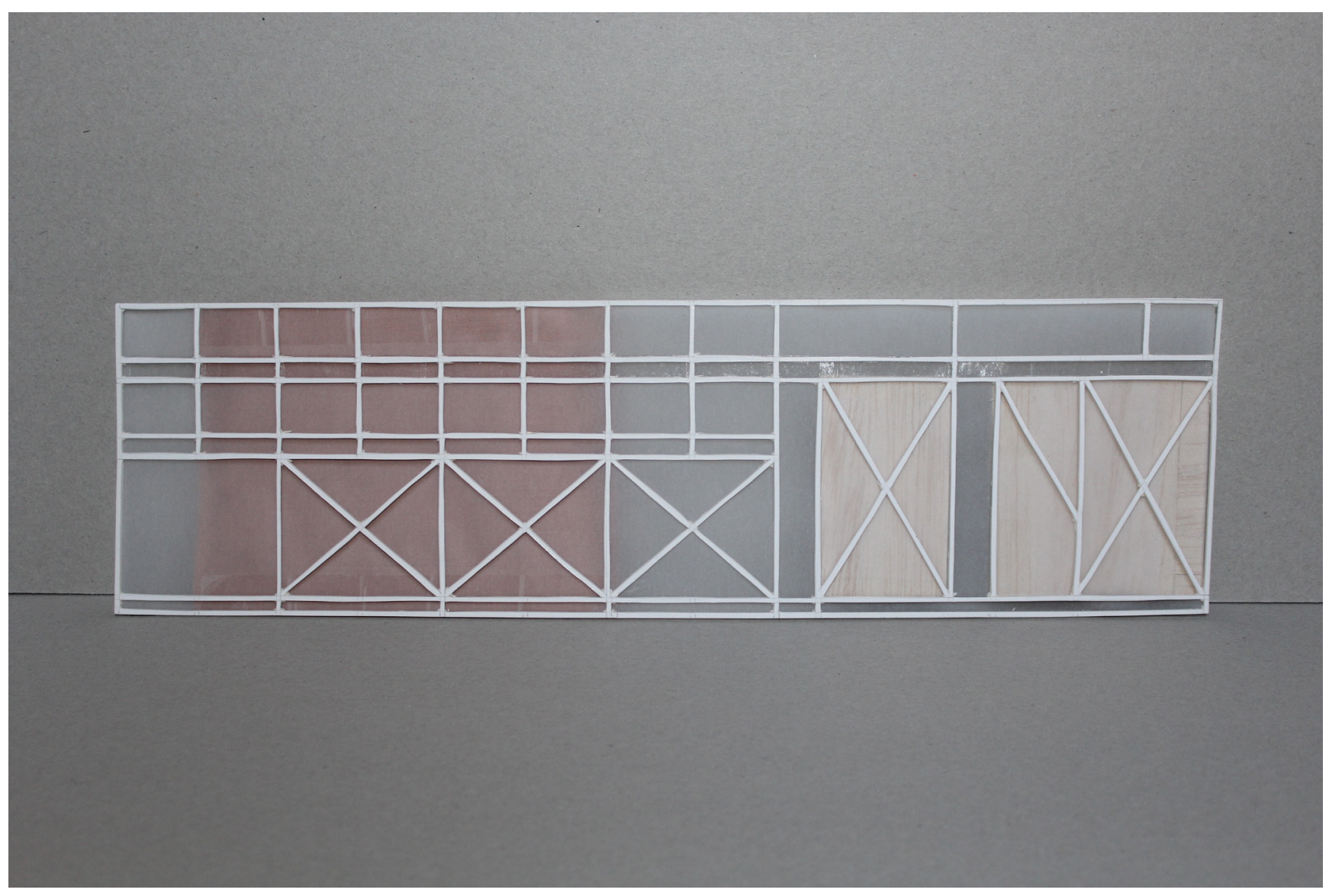

Model of sliding doors.

Modelling the sliding door that divides boardwalk and home allowed for exploration of opacity and materiality. This concept is more refined in the way that it blocks textured panels together, simplifying the concept. 


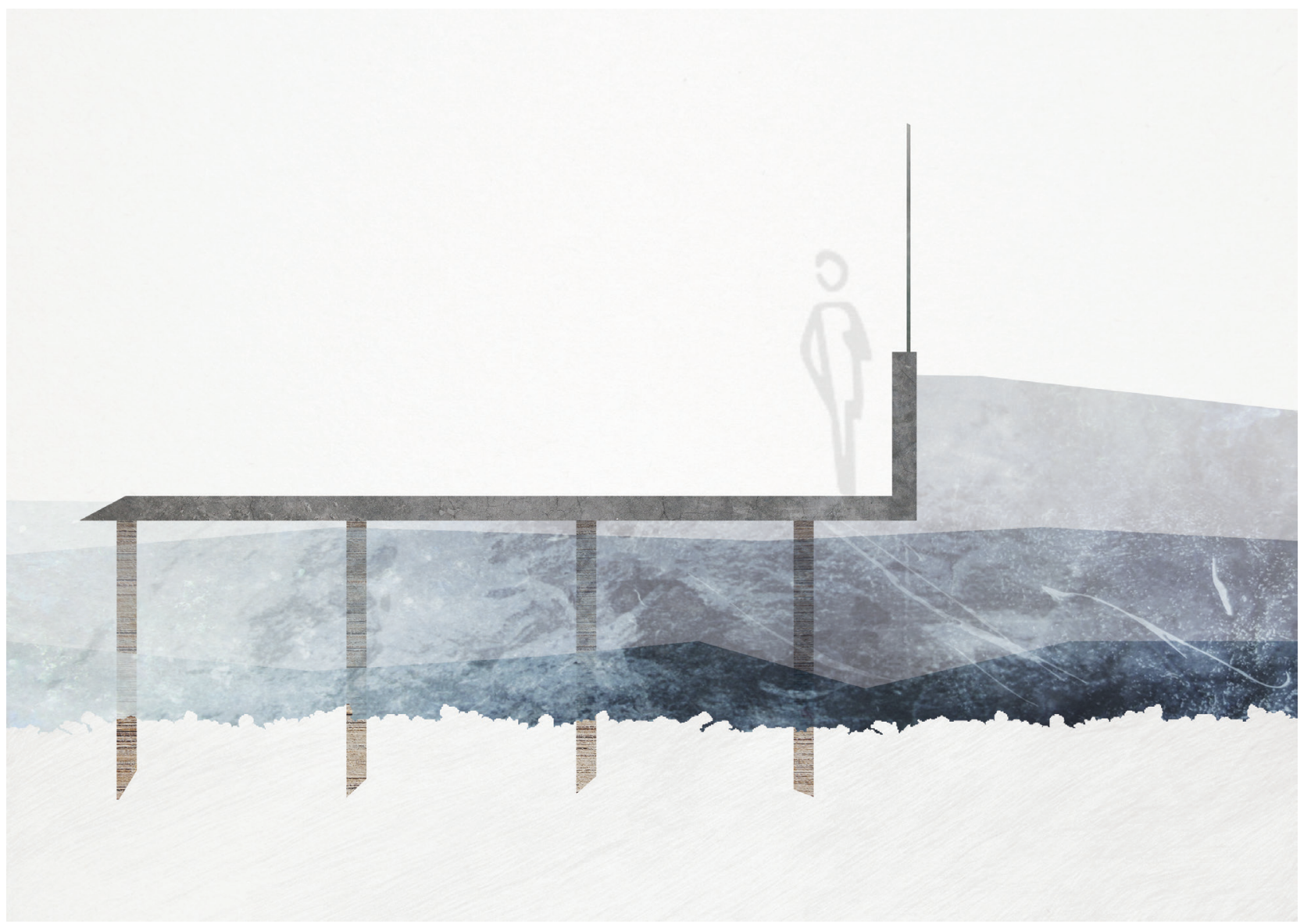

Interaction between water levels and building.

Due to the building being situated on the wetlands, it is important that

fluctuating water levels be accounted for. This image shows how continuing the concrete floor slab up the wall plane would allow for the water level to rise above the ground plane without entering the building. This method would however need to be used in conjunction with a system to block the doorways, and might therefore be impractical. 
FIGURE 86
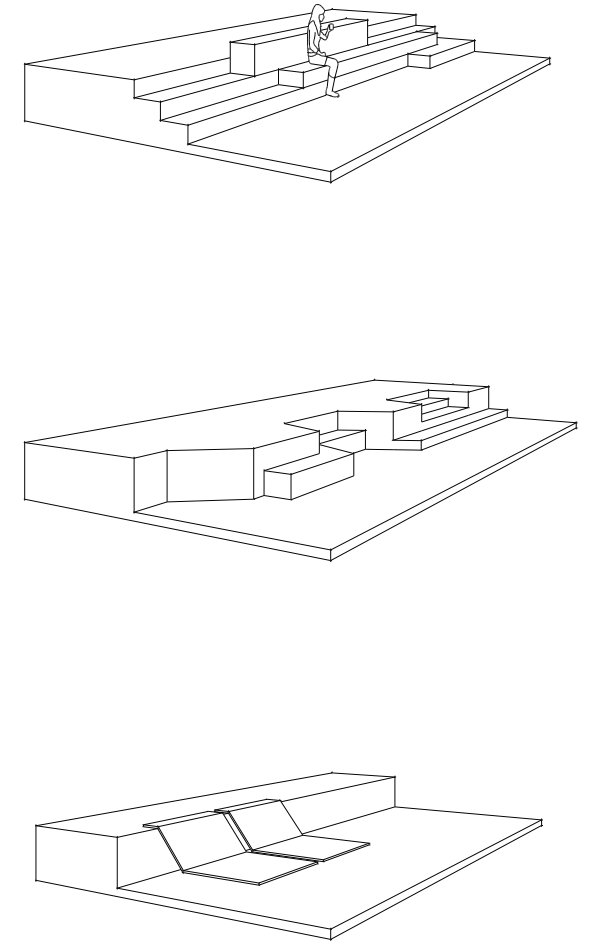
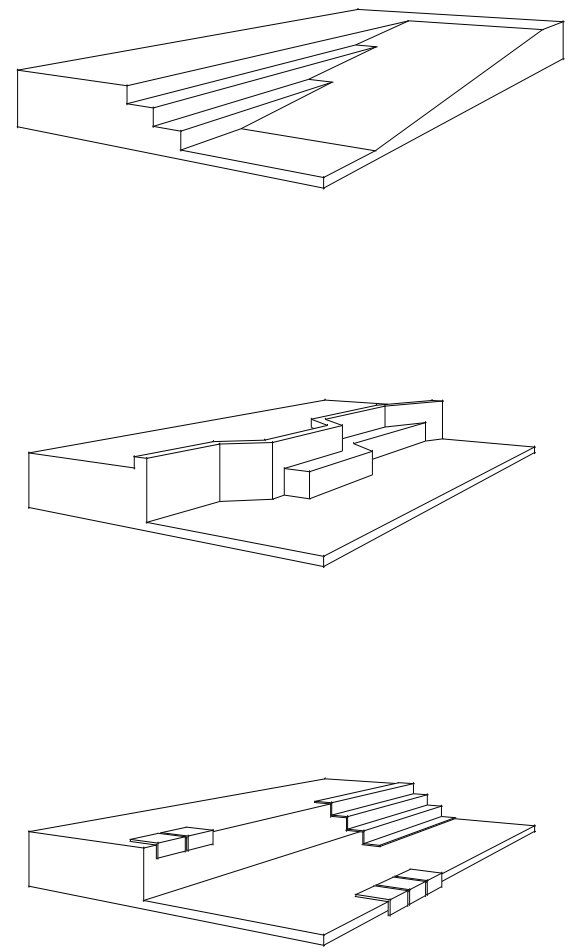
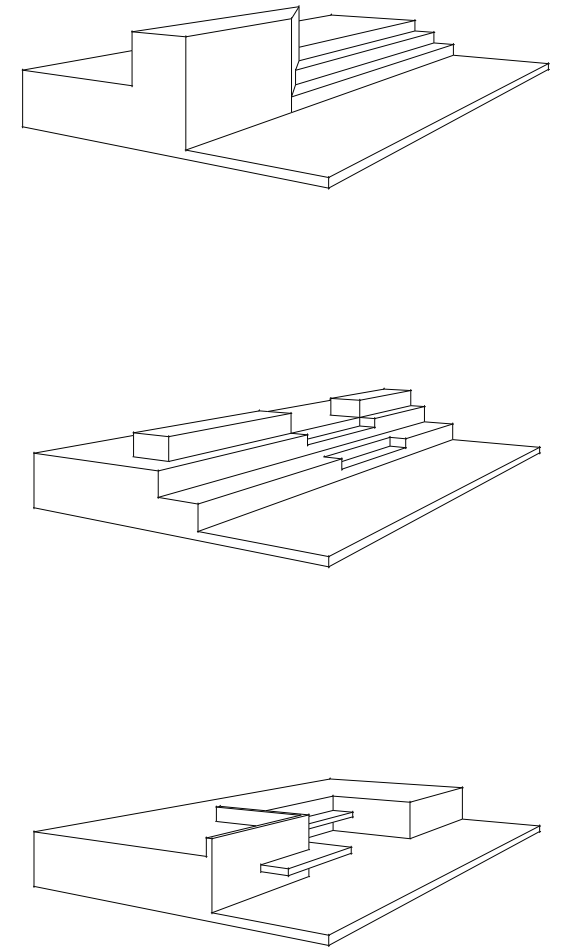

Seating concepts.

Iterative images explore

options of how levels

might be used in a public

seating system to allow

for a fluctuating water

level while maintaining

a closeness between

the visitor and wetland

system. 

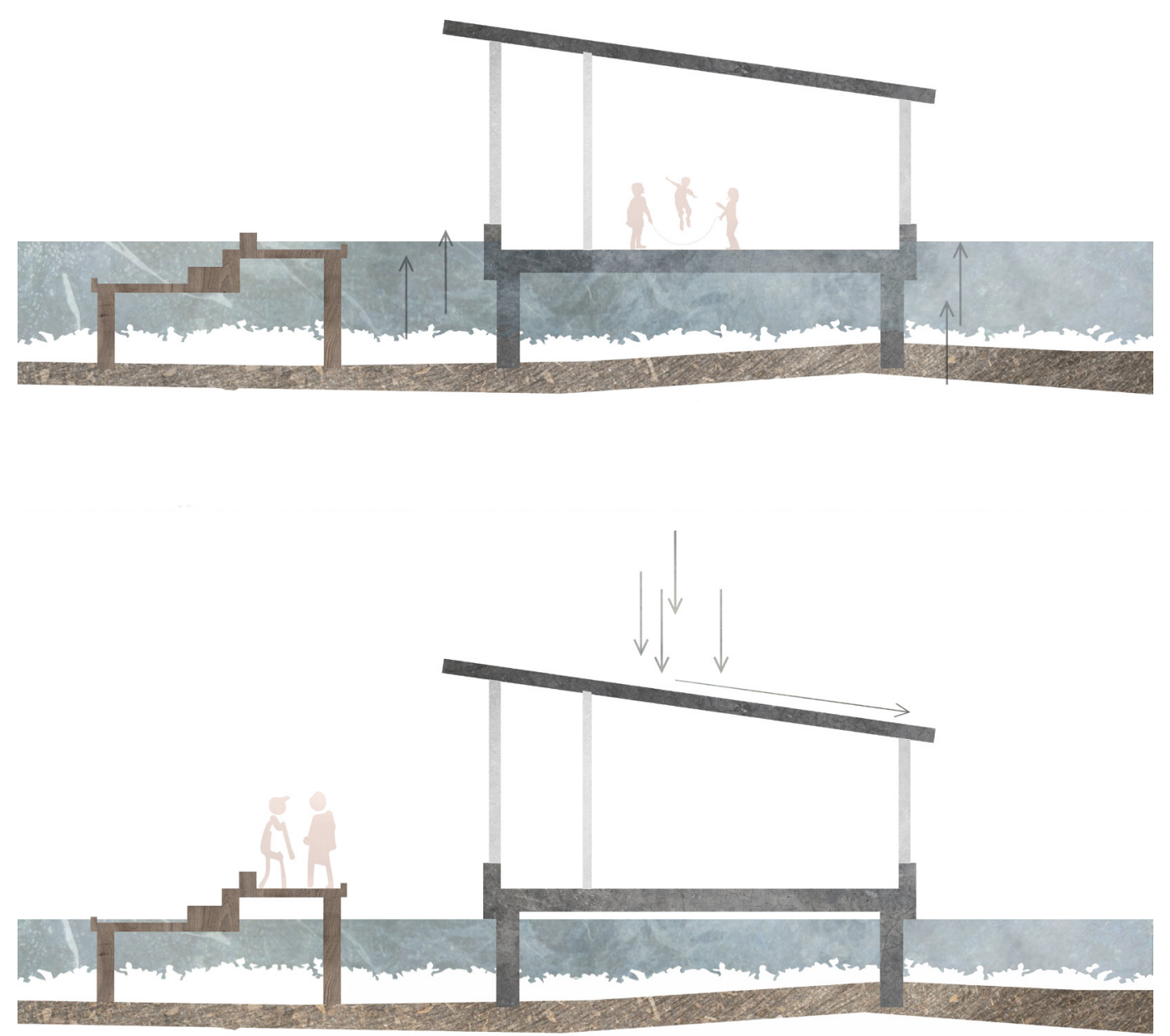

Concept in flash flood.

In the case of a flash flood, the raised walls as an extension of the floor slab allow for extreme rise in water level, while enabling people to stay dry inside.

FIGURE 88

Concept in rain.

During rainy periods, the staggered boardwalk system ensures that the main section of the walkway is still easily useable. 


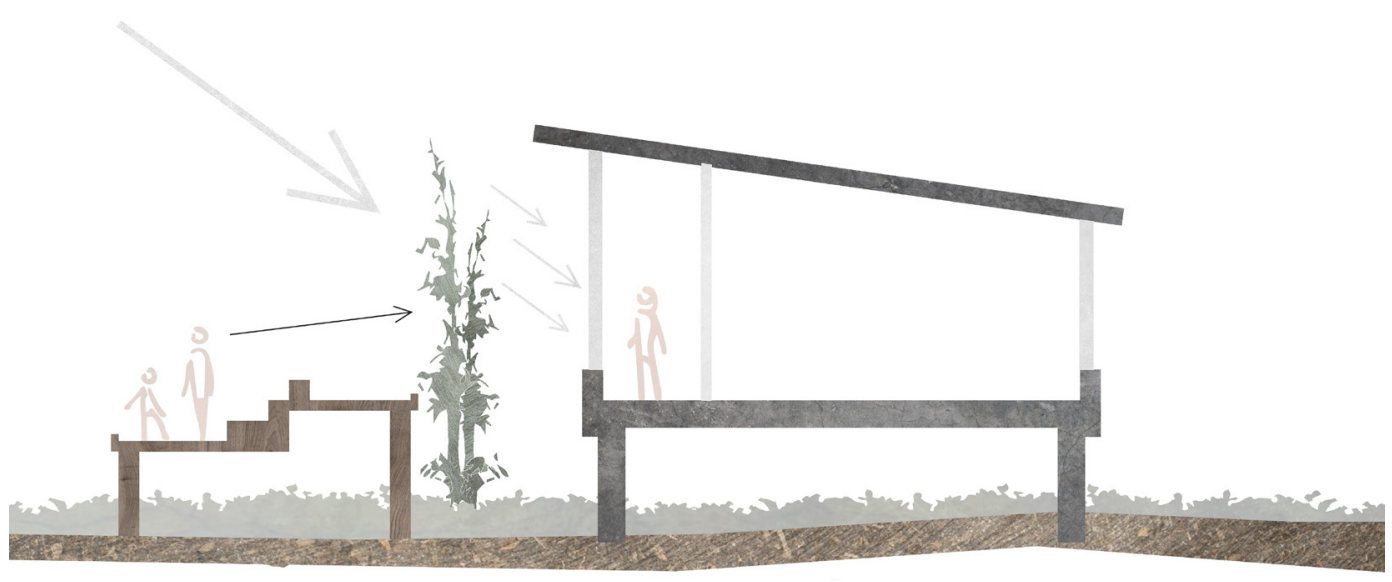

FIGURE 89

Concept in sun.

Due to the hallway in the concept being exposed to large amounts of sunlight, planting will be used to provide privacy and filter sunlight.

FIGURE 90

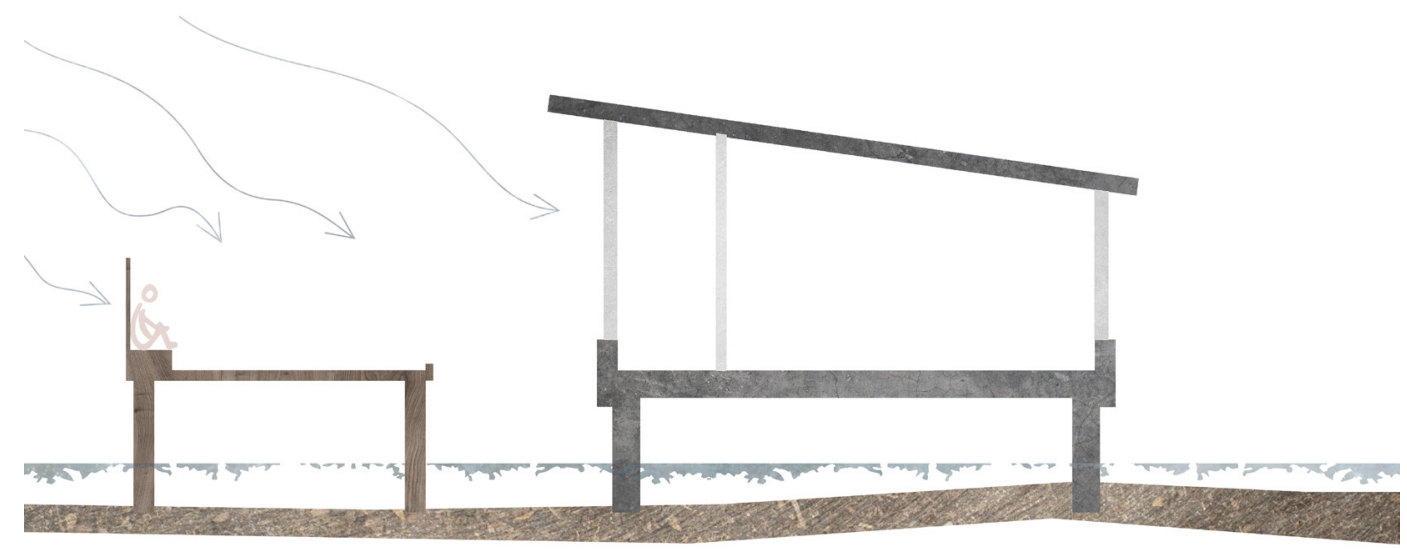

Concept in wind.

In the case of high wind

levels, panels might

be used to shelter the

boardwalk system from

direct wind. This however

may interrupt views across

the site. 


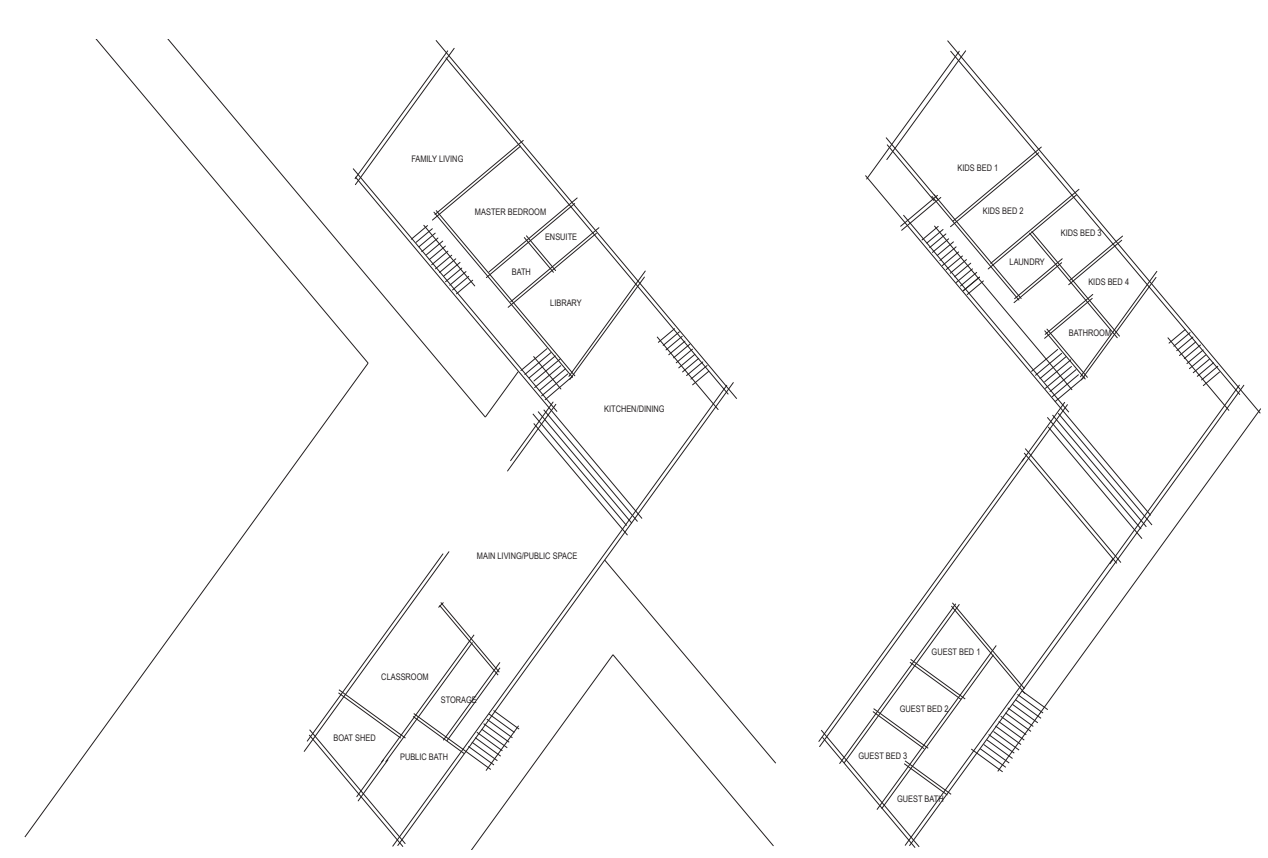

FIGURE 91

Concept floor plans 3.

Splitting the floor plates into two levels shortens

the hallway spans. Raising the family and guest bedrooms up above the boardwalk creates a greater level of privacy.

FIGURE 92

Concept floor plans 4.

Shrinking spaces that were too large left the building looking overly fragmented. This detracted from the simple geometry of the building.
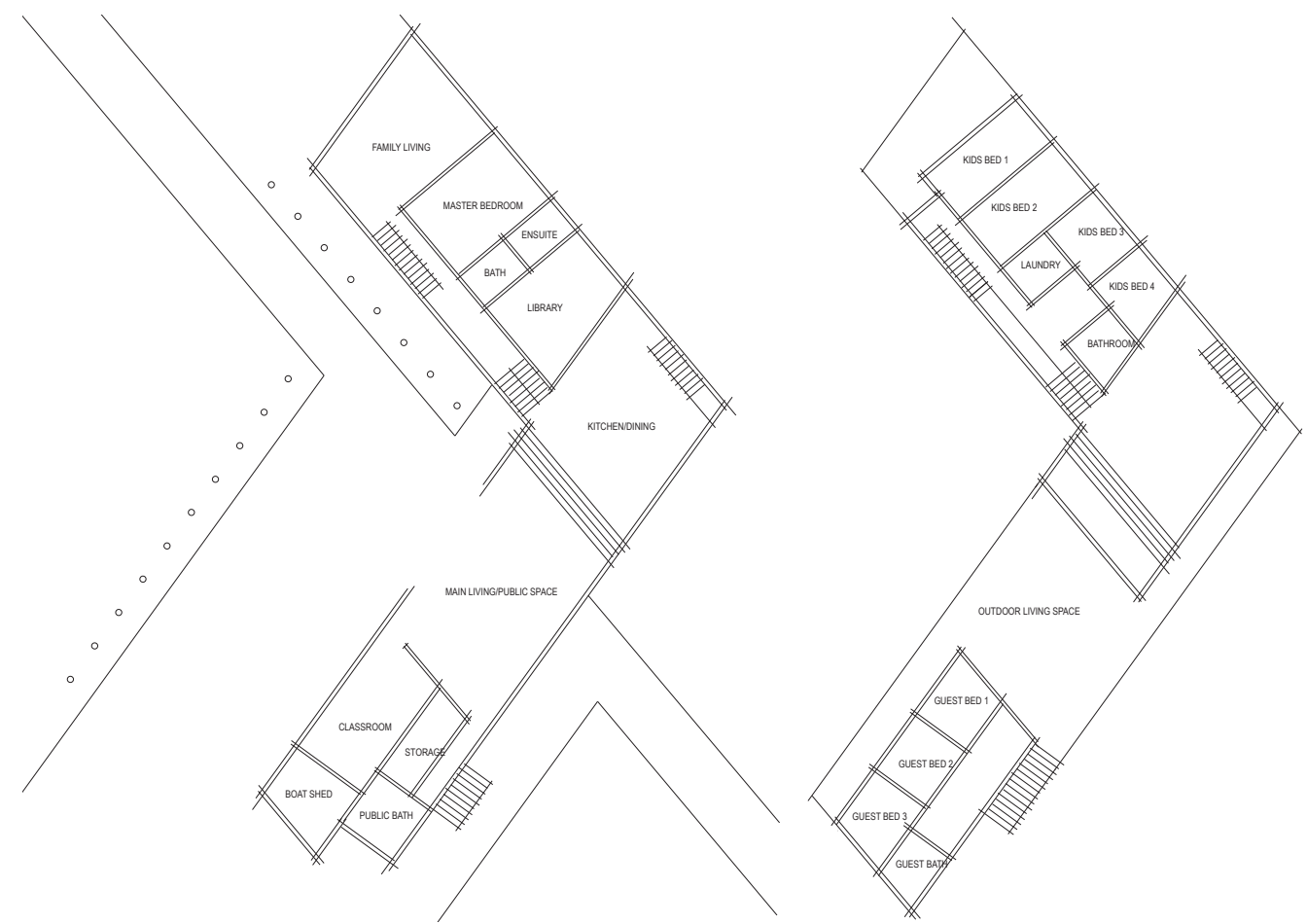


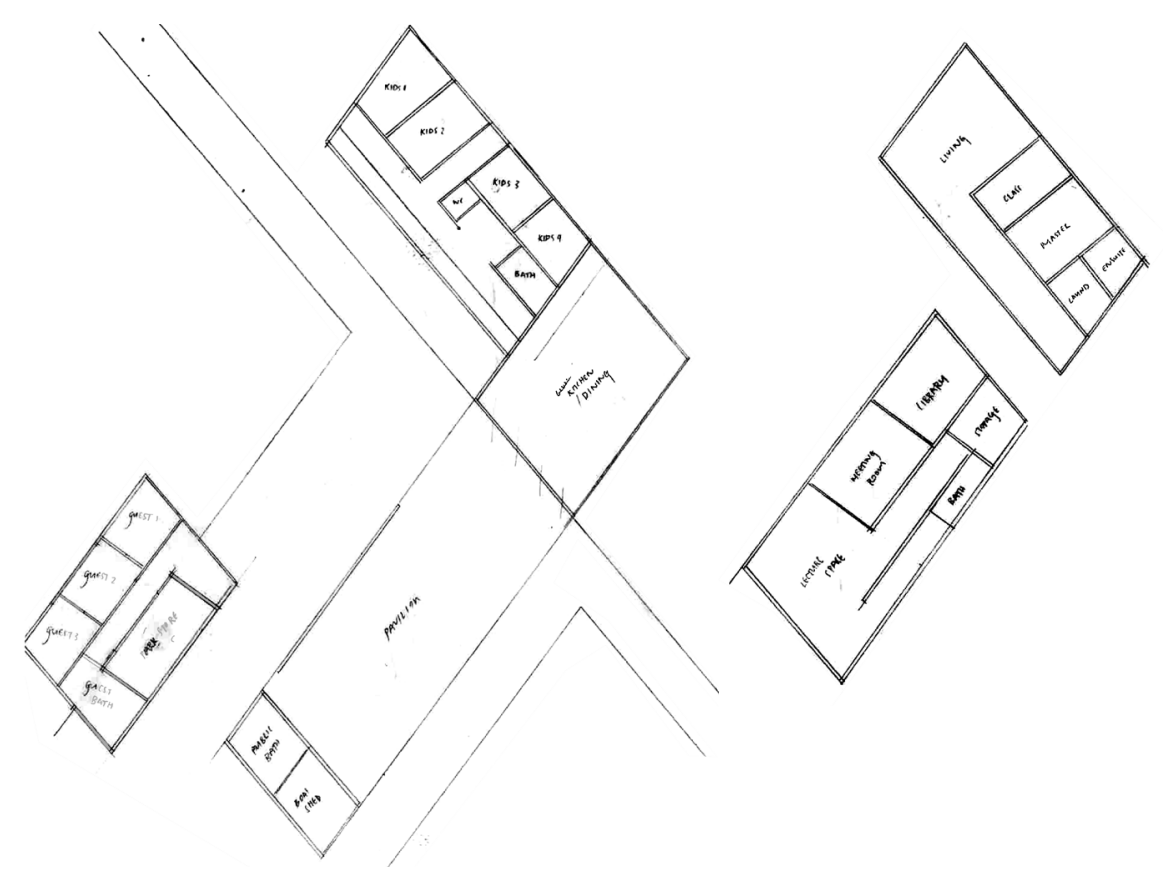

FIGURE 93

Concept floor plans 5.

Sinking the second level below the boardwalk

system begins to establish a more interesting

connection between the wetland system and the building. The layout of the building sections remains largely fragmented in this concept.

FIGURE 94
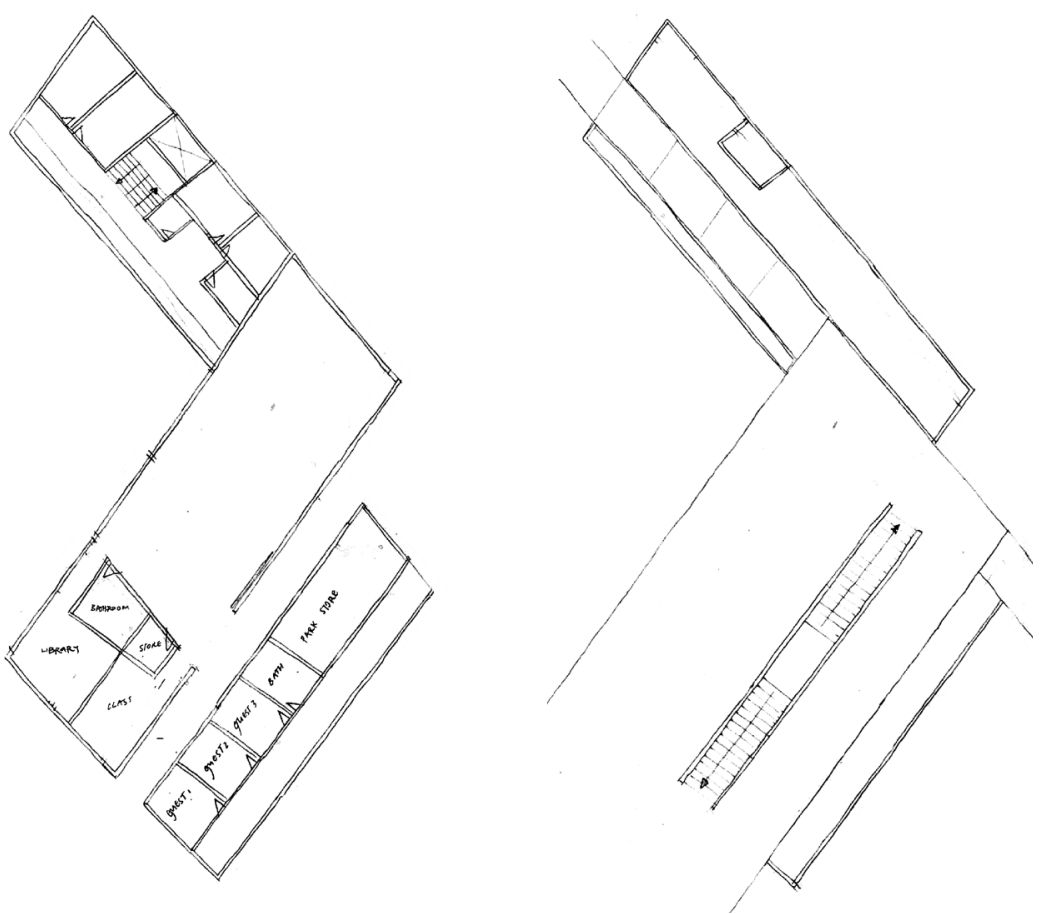


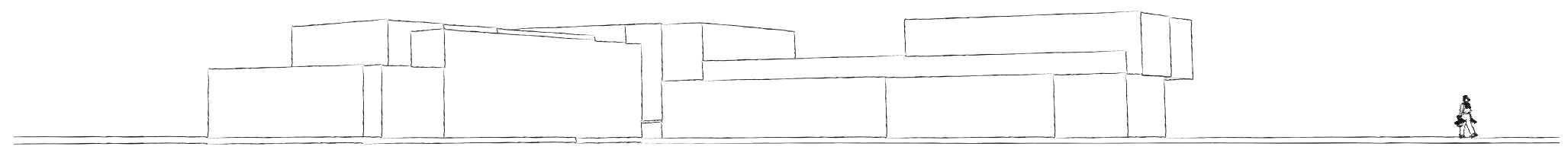

FIGURE 95

Perspective sketches of floor plan concepts.

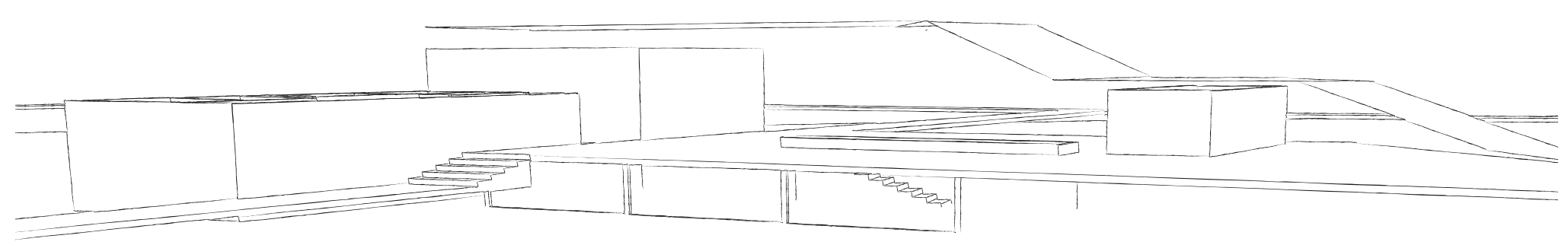

Looking at the concept in perspective sketches shows the strength in clearing solid masses from the boardwalk level. This leaves the design less cluttered and more inviting to visitors of the park.

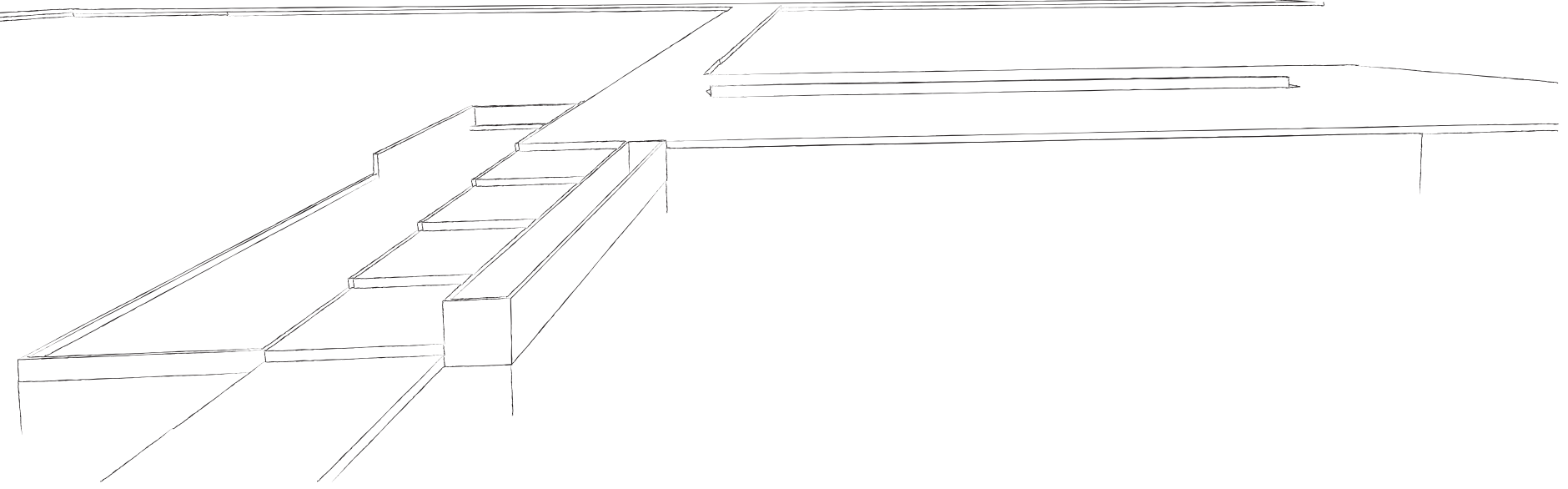




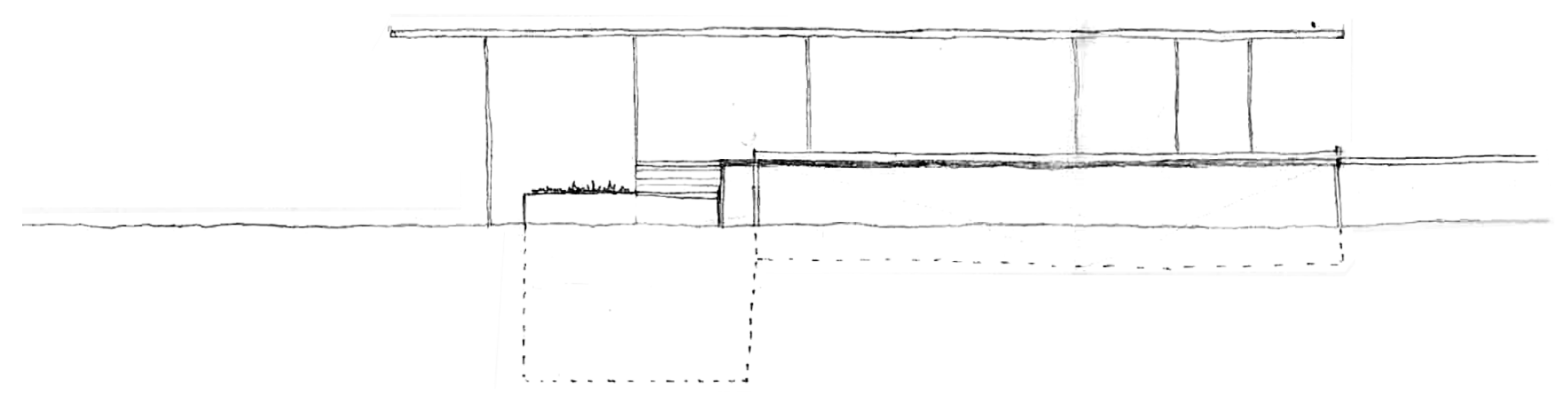

FIGURE 96

Elevation sketches of building canopies.

Leaving the boardwalk level as an open pavilion means that it is also exposed to the elements more severely. This can be minimised by adding a canopy to the design. Adding a canopy opened the opportunity to make this level accessible, which then led to the concept of shifting some of the spaces to this level.

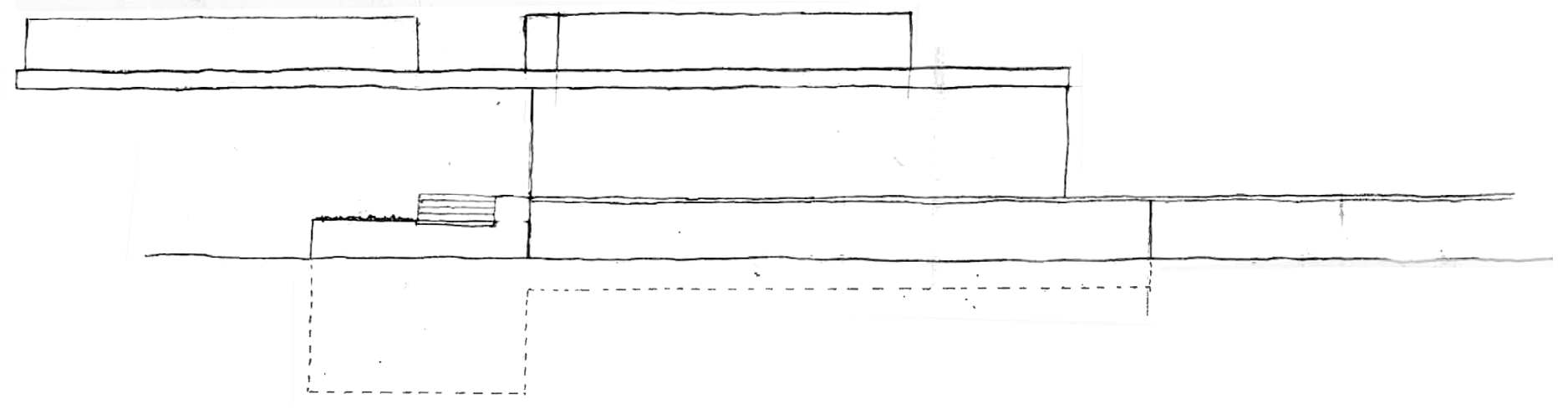



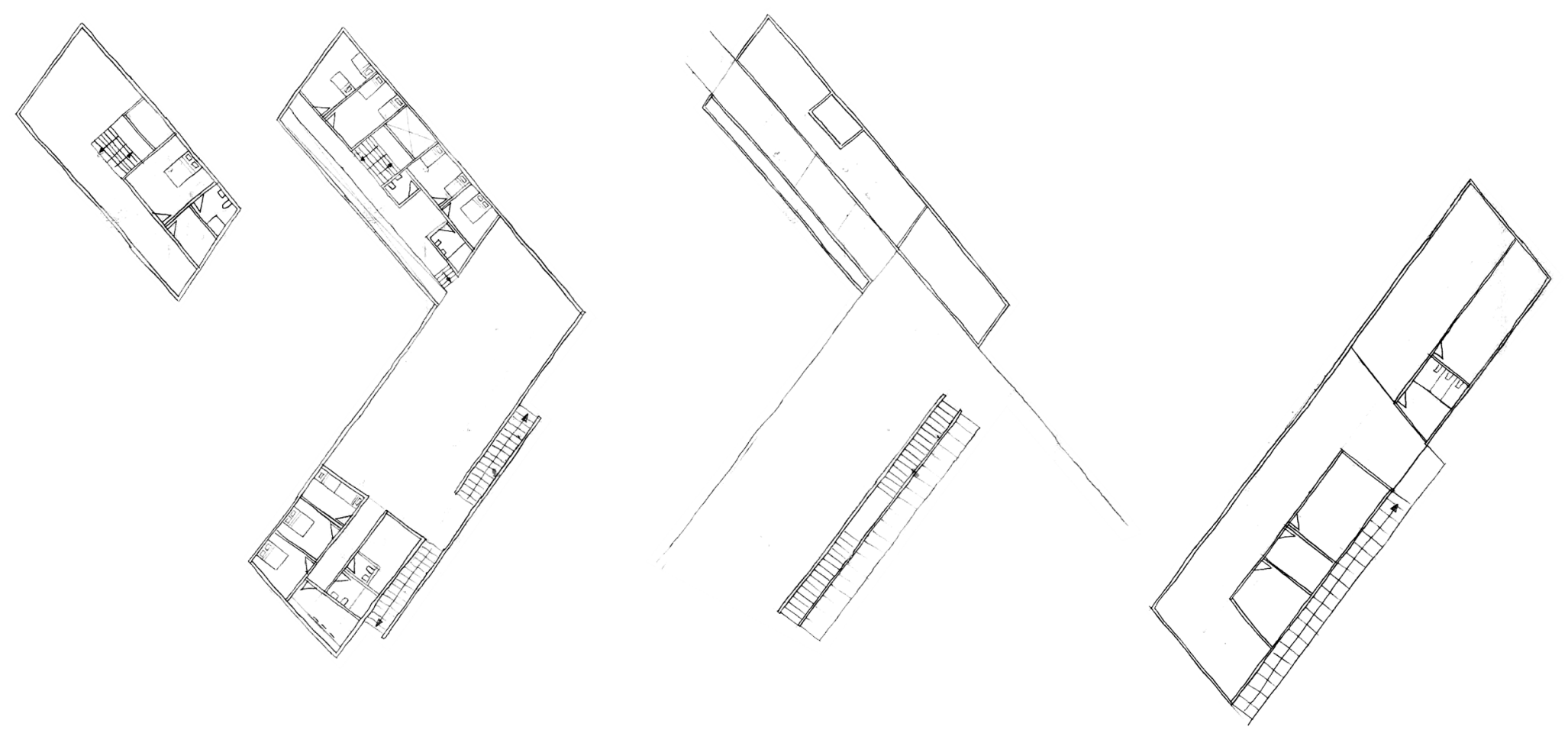

FIGURE 97

Concept floor plans 7 .

This concept looks further into the idea of having an open pavilion level between two enclosed levels. This leads people via the boardwalk right into the centre of the building without them realising they are crossing the threshold. This concept still has two basement levels, which may not be a comfortable space to inhabit.

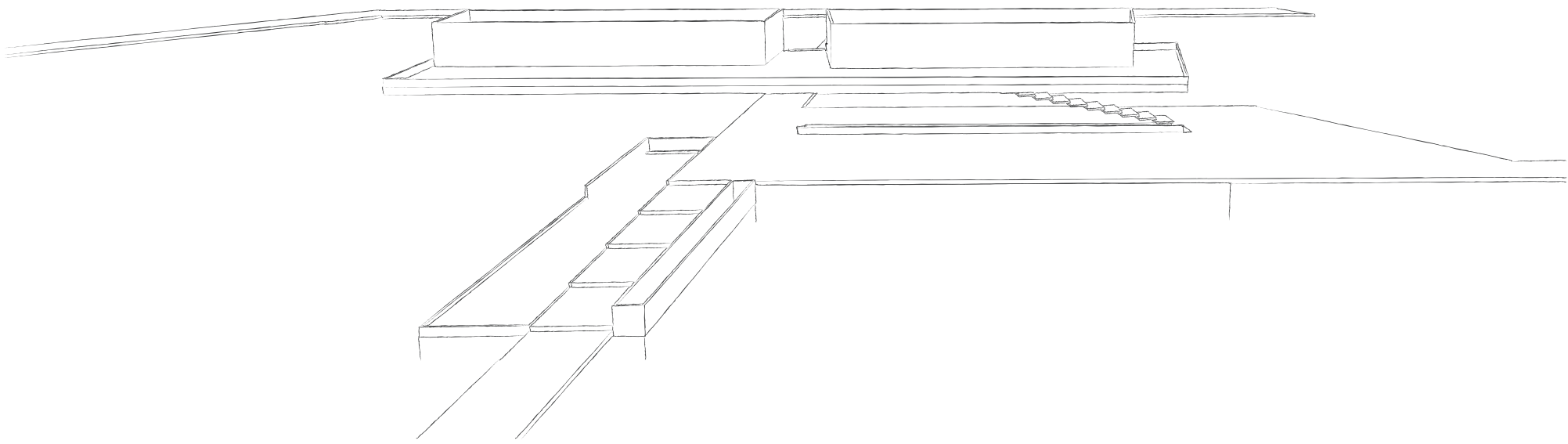




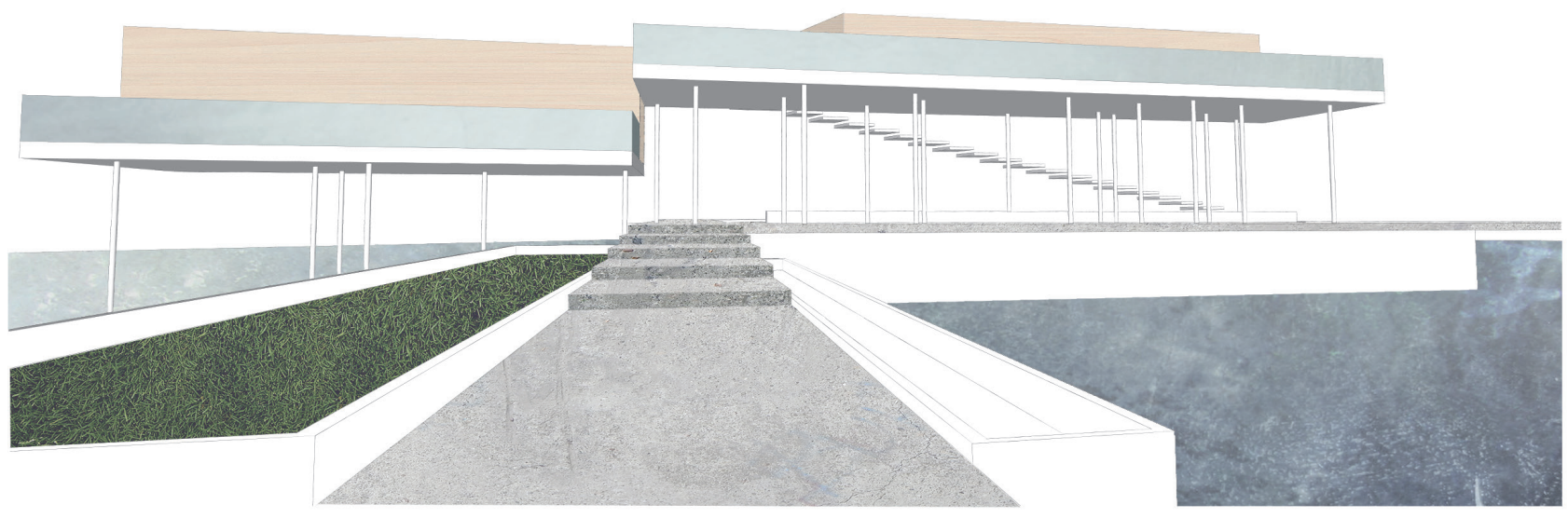

FIGURE 98

Perspective images of pavilion level.

The boardwalk leading directly into the pavilion space. This encourages people to engage with the space without realising they are crossing a threshold.

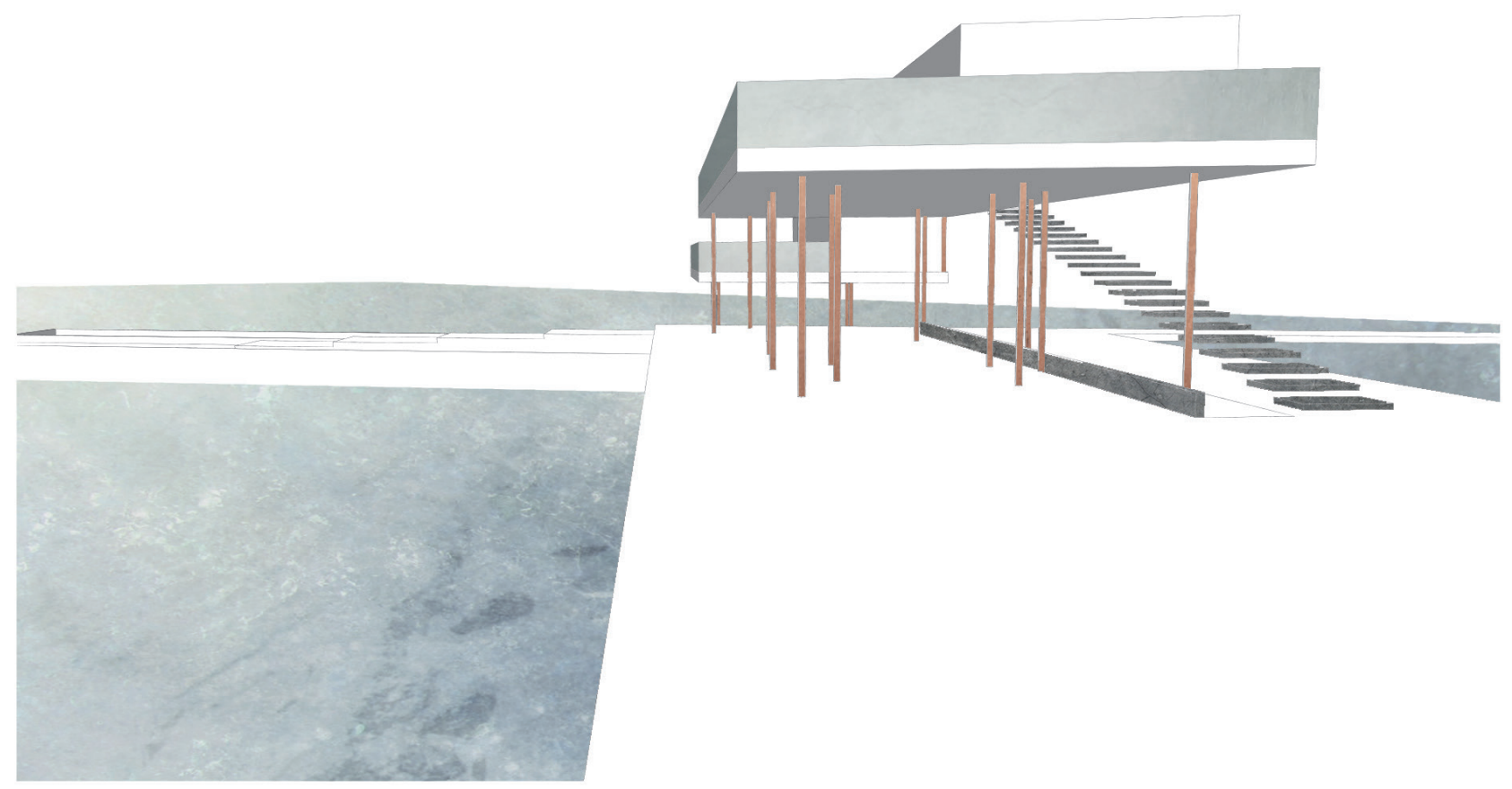




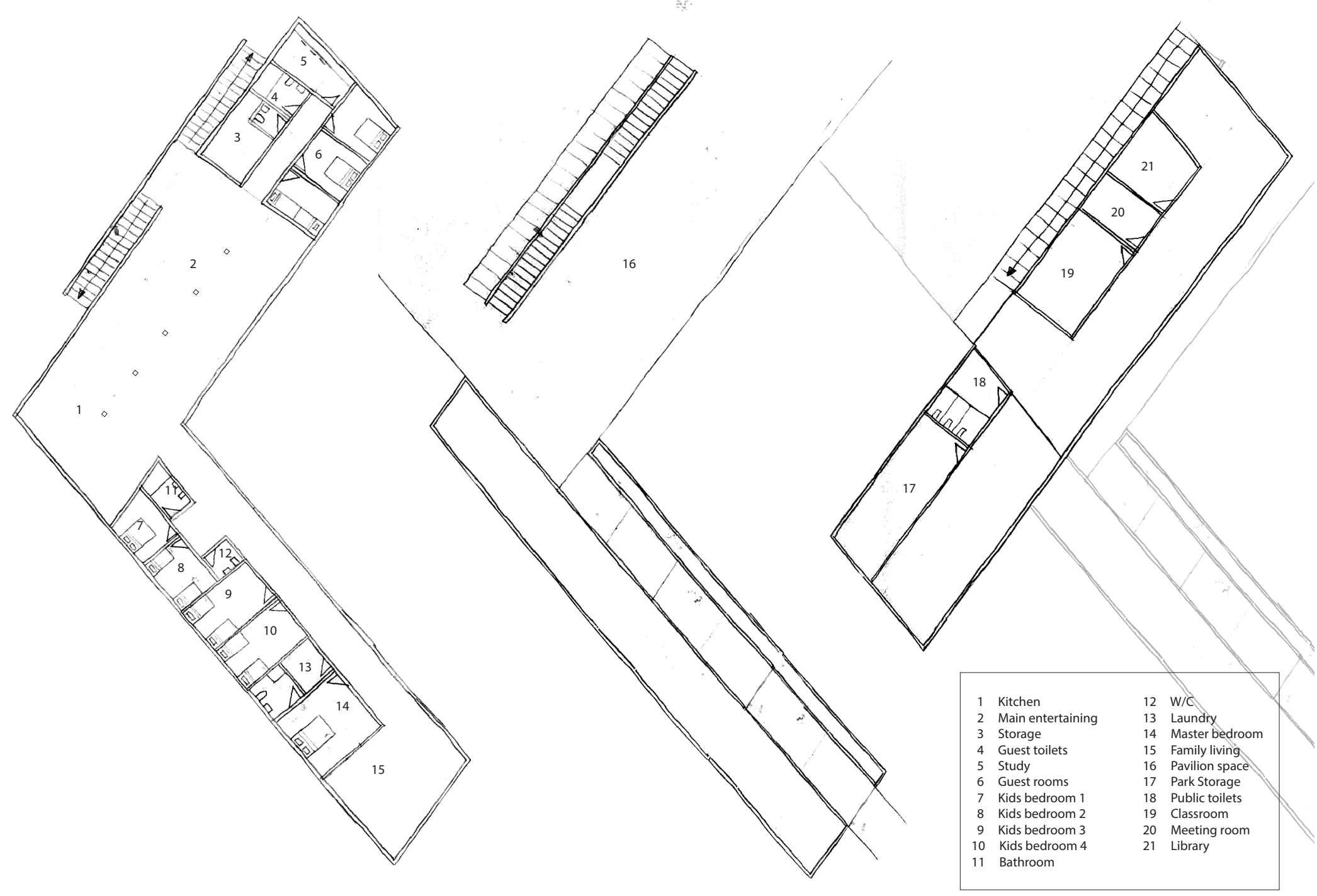

FIGURE 99

Concept floor plans 8 .

While the pavilion level in the centre is successful, the orientation of the private spaces being below the boardwalk system might not be a pleasant living environment for the family. Instead it might be desirable to bring these up above the pavilion level to take advantage of the views and allow for the ranger to easily look out over the site. 

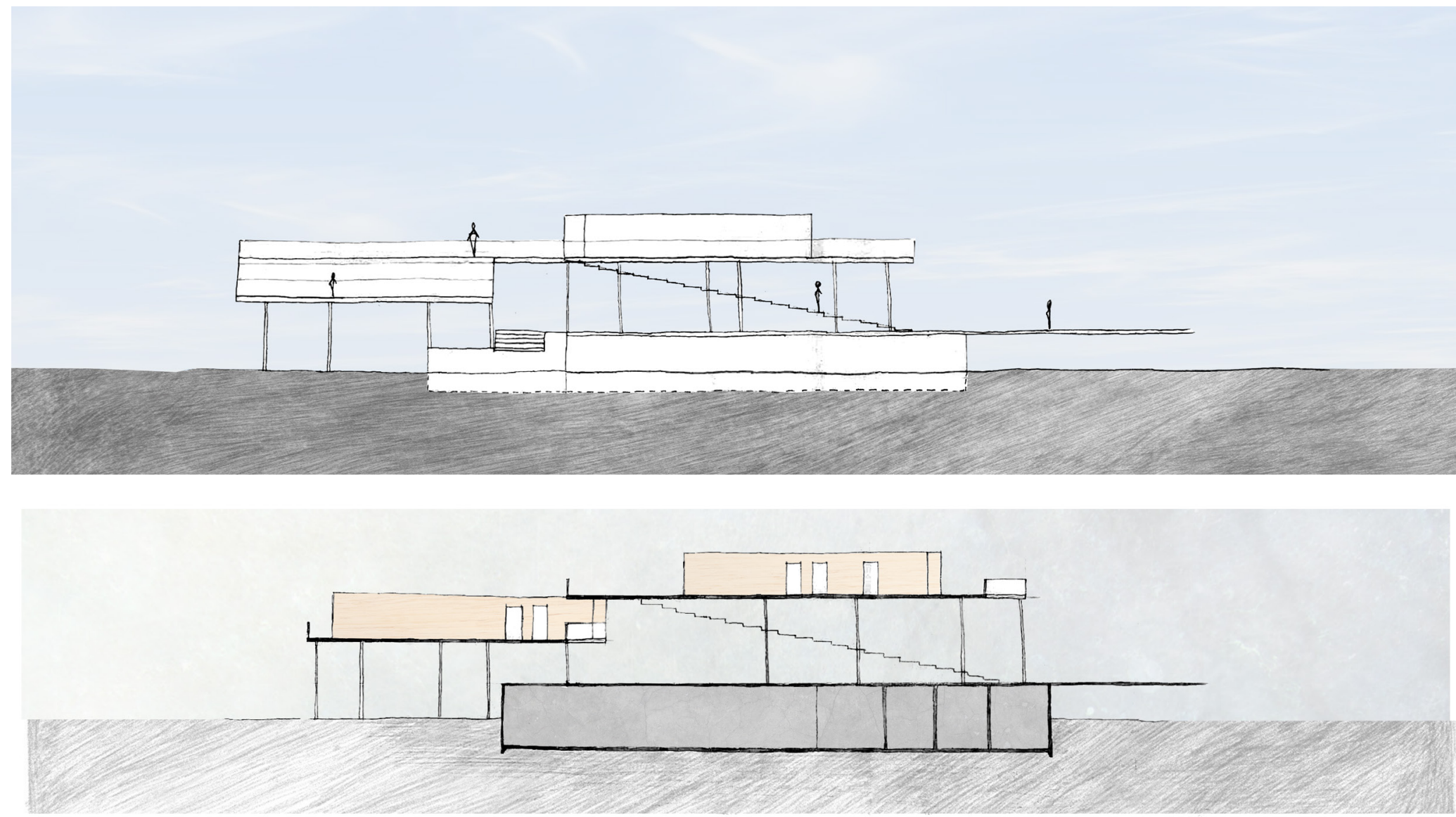

Sectional images showing section through concept levels.

Ignoring the space usages, the sectional images show the success in the building levels. Dividing the space vertically creates a range of public and private spaces. It also allows for inhabitants to experience the site from different vantage points. 
Sketches showing building usage.

Creating spaces to facilitate different types of events is important in creating a resilient building. This is achieved by creating large open spaces in which furniture can be easily moved to alter the usage of the room.

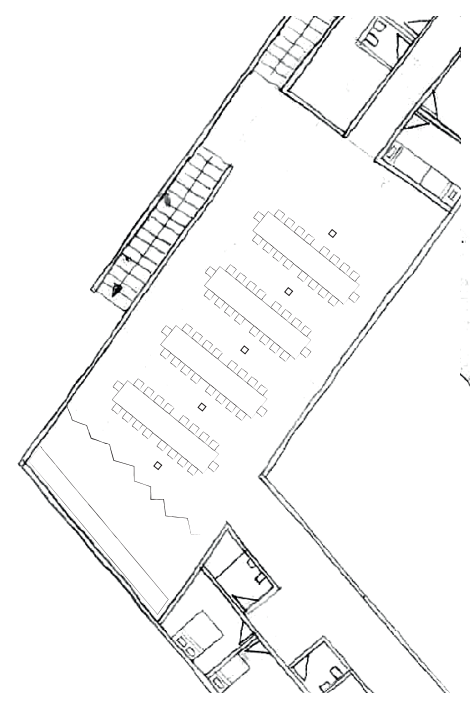

BANQUET

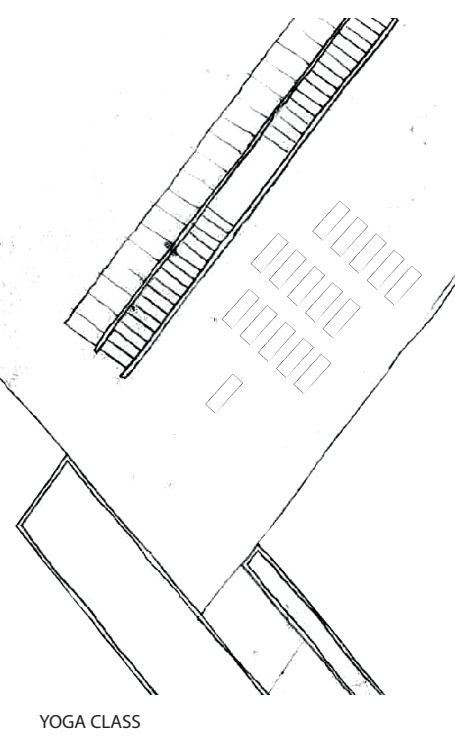

YOGA CLASS

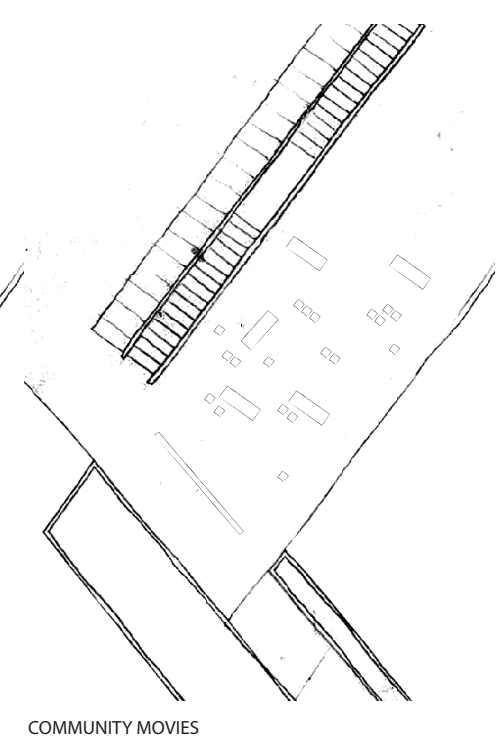

COMMUNITY MOVIES 

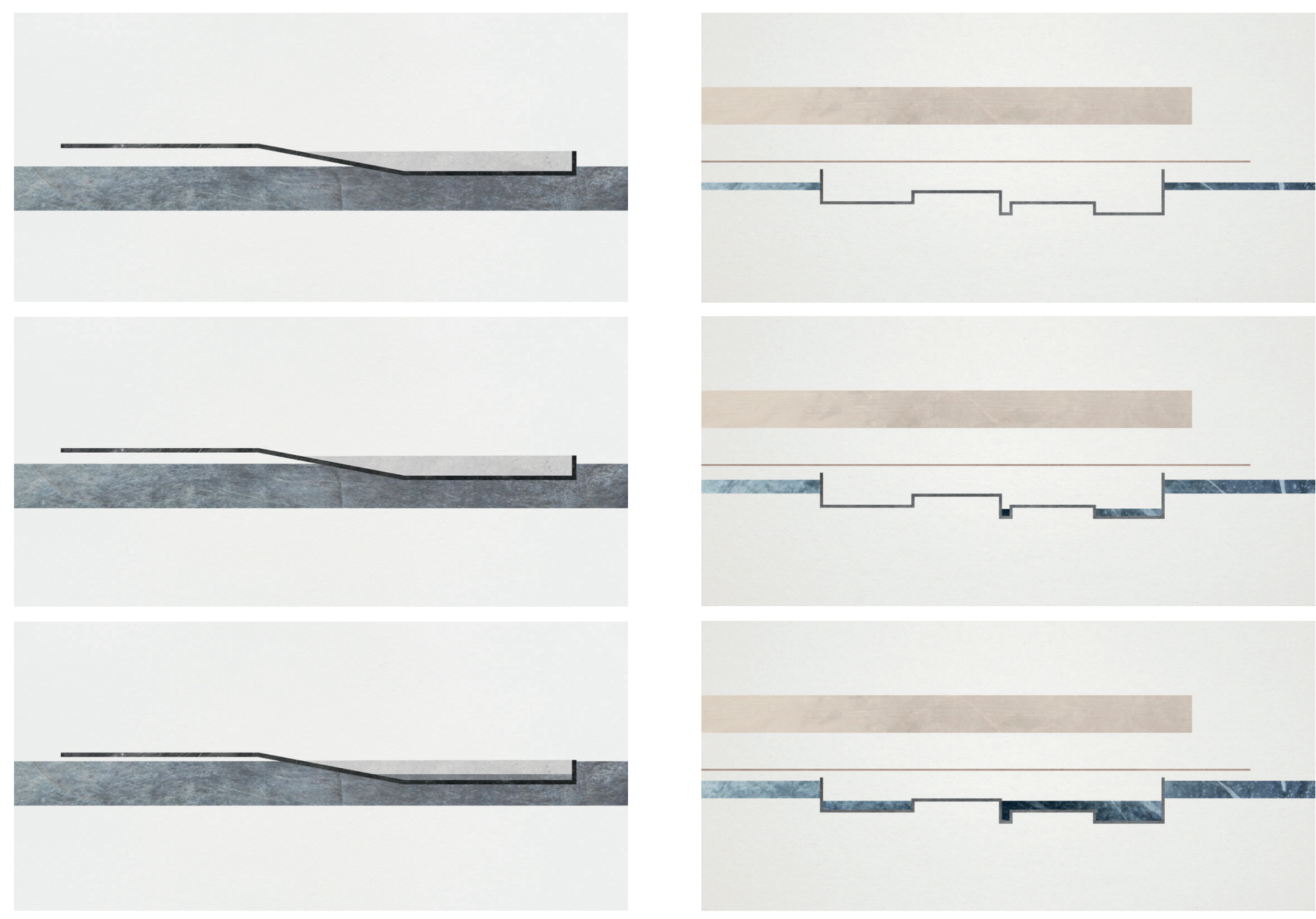

FIGURE 102

Relationship between floor and water levels.

Iterations explore opportunities for variations in floor levels within the basement level. In the case of water entering the space, it would pool in the lower areas, leaving other areas dry. This concept of sacrificial spaces may interrupt the usability of the space. As an alternative, items which are not to get wet will not be stored in this basement level. 
Allen, Laura. Research Output 2: The Retreating Village. Bartlett School of Architecture, 2008. http://discovery.ucl. ac.uk/9740/1/9740.pdf

Blundell, Kay. "Kapiti Erosion Risk May Devalue 1800 Homes." The Dominion Post. Aug. 27, 2012. http://www.stuff. co.nz/dominion-post/news/kapiti/7555304/Kapiti-erosion-risk-may-devalue-1800-homes

"Church on the Water." Architectuul. Accessed Nov. 20, 2016. http://architectuul.com/architecture/church-on-thewater

"Ecclesia." Encyclopaedia Brittanica. Jul. 20, 1998. https://www.britannica.com/topic/Ecclesia-ancient-Greek-assembly

Frayling, Christopher. "Provocation by Sir Christopher Frayling Part 1: Research Through Design Evolution." By Abigail Durrant and James Price, 2015. Vimeo video, 7:08. Posted Jun. 4, 2015. https://vimeo.com/129775325

"From Swamps to Wetlands." Envirohistory NZ. Dec. 6, 2009. https://envirohistorynz.com/2009/12/06/from-swampsto-wetlands/

Greater Wellington Regional Council. Queen Elizabeth Park Resource Statement. Wellington, NZ: GWRC, 2008. Doi: GW/PF-G-07/292.

Greater Wellington Regional Council. Understanding the 'wet' in wetlands. Wellington, NZ: GWRC, 2005. Doi:GW/ RP-G-05/35. 
Holling, C. "Resilience and Stability of Ecological Systems." Annual Review of Ecology and Systematics 4, (1973): 1-23

"HUD - The Big U." Bjarke Ingels Group. Accessed Mar. 30, 2016. https://big.dk/\#projects-hud

"Installing Solar Panels." Builder's Mate. Feb. 2010. Issue 40. Page 2. http://www.branz.co.nz/cms_show_download. php?id=b2528e5315a7091c480aaa3536b84a192e6d26c1

"Kroll, Andrew. "A.D. Classics: Church of the Light". ArchDaily. Accessed Nov. 20, 2016. http://www.archdaily. com/101260/ad-classics-church-of-the-light-tadao-ando

Lepi, Katie. "The 7 Styles of Learning: Which Works For You?" Edudemic. Nov. 27, 2012. http://www.edudemic. com/styles-of-learning/

"ᄀNZ Solar PV Panel Calculator." Mitsubishi Electric. Accessed Feb. 1, 2017. http://www.mitsubishi-electric.co.nz/ solar/selector.aspx

Ok, Yong Sik, Sophie Uchimiya, Scott Chang and Nanthi Bolan. Biochar: Production, Characterization and Applications. CRC Press, 2015.

Oxford Dictionary, s.v. "Embassy," Accessed Jan. 10, 2017. https://en.oxforddictionaries.com/definition/us/embassy

Oxford Dictionary, s.v. "Home," Accessed Jan. 10, 2017. https://en.oxforddictionaries.com/definition/home

Peters, Monica and Beverly Clarkson. "Revegetation". In Wetland Restoration: A Handbook for New Zealand Freshwater Systems. 2. Hamiltion, NZ: Print House Ltd, 2012. Doi: UDC 574(931:252.6). 
"Profile: Using biochar for water filtration in rural South East Asia." International Biochar Initiative. Oct. 2012. http:// www.biochar-international.org/profile/water_filtration

Queen Elizabeth Park - History." Greater Wellington Regional Council. Last modified Nov. 29, 2016. http://www. gw.govt.nz/History-4/

Shand, Roger. Kapiti Coast Erosion Hazard Assessment. Wanganui, NZ: Coastal Systems Limited, 2008. http://www. kapiticoast.govt.nz/contentassets/a933446e8c094de8a946d20b9f36a1de/kapiti_coast-erosion_hazard_assessment_ part1_open_coast.pdf

Turner, Harold. From Temple to Meeting House. Berlin/Boston: De Gruyter, 1979. ProQuest Ebook Central.

"Water Temple." Architectuul. Accessed Nov. 20, 2016. http://architectuul.com/architecture/water-temple

Whareroa Stream at Queen Elizabeth Park." Land Air Water Aotearoa. Accessed Dec. 20, 2016. https://www.lawa.org. nz/explore-data/wellington-region/river-quality/whareroa-stream/whareroa-stream-at-qe-park/

"What is the task of an Embassy?" Renaca. Accessed Jan. 10, 2017. http://www.renaca.ch/wasmacht-en.html

"Why Wetlands". National Wetland Trust of New Zealand. Accessed Oct. 10, 2016. http://www.wetlandtrust.org.nz/ Site/Why_Wetlands.ashx 
Figure 1. Layout collage 1.

Figure 2. Layout collage 2.

Figure 3. Layout collage 3

Figure 4. Section of site.

Figure 5. Concept section.

Figure 6. The end of the wall.

Figure 7. Interior/exterior threshold.

Figure 8 . Study of a wall 1.

Figure 9. Study of a wall 2.

Figure 10. Study of a wall 3.

Figure 11. The wall.

Figure 12. The decay.

Figure 13. Wartime training camp. Reproduced

from http://www.gw.govt.nz/assets/ Parks-and-

Recreation/Misc/QEP-resource-statement.pdf

Figure 14. Disconnecting communities.

Figure 15. Pollution of Whareroa Stream.

Reproduced from https://www.lawa.org.nz/

explore-data/wellington-region/river-quality/

whareroa-stream/whareroa-stream-at-qe-park/
Figure 17. Resilience strategies.

Figure 18. The Retreating Village. Reproduced from http://discovery.ucl.ac.uk/9740/1/9740. pdf Figure 19. The Dryline. Reproduced from https:// big.dk/\#projects-hud

Figure 20.The Water Temple. Reproduced from http://www.jaredlockhart.com/ outonsite sunday-on-awaji-island/

Figure 21.Church on the Water.

Reproduced from http://www.pritzkerprize com/1995/works

Figure 22. Church of Light. Reproduced from http://openbuildings.com/buildings/church-ofthe-light-profile-2976

Figure 23. Current site.

Figure 24. Site after wetland reinstatement.

Figure 25. Letting the water in.

Figure 26. The low point. Reproduced from http://www.gw.govt.nz/assets/Parks-andRecreation/Misc/QEP-resource-statement.pdf Figure 27. Wetland system. Adapted from image at http://www.sundaytimes.Ik/110227/FunDay/ fut 05. html

Figure 28. Dune to wetland in section. 

http://www.wetlandtrust.org.nz/Site/Why_

Wetlands.ashx

Figure 30. The ranger's hut.

Figure 31. Floor plans.

Figure 32. The hallway.

Figure 33. Family portrait.

Figure 34. Family spatial needs

Figure 35. Family spaces and the boardwalks.

Figure 36. Section through children's bedrooms.

Figure 37. Section of the ranger's hut.

Figure 38. Elevations of ranger's hut

Figure 39. The shelves.

Figure 40. The entry.

Figure 41. The watchtower.

Figure 42. The dining table.

Figure 43. Movie night floor plans.

Figure 44. Community movie night.

Figure 45. Banquet floor plans.

Figure 46. Banquet style event.

Figure 47. Learning styles. Definitions

reprpduced from http://www.learning-styles-

online.com/overview/

Figure 48. Solitary learning spaces.

Figure 49. Ranger's library.
Figure 50. Social learning spaces.

89 Figure 51. Large seminar style event.

90 Figure 52. Current gateway.

92 Figure 53. New gateway.

93 Figure 54. The community garden.

95 Figure 55. Rainbow Cres entrance.

96 Figure 56. Bringing the community together.

$98 \quad$ Figure 57. Site Plan.

99 Figure 58. Ranger's hut on axis.
Figure 59. History in Facade.

Figure 60. Public seating.

Figure 61. Section study of relationship between visitor and site

Figure 62. Light qualities in basement.

Figure 63. Water treatment system. Adapted

from image at http://www.biochar-international. org/profile/water_filtration

Figure 64. Solar energy harvesting.

Figure 65. Dunes at Queen Elizabeth Park.

Figure 66. Sea wall structures.

Figure 67. Massing models.

Figure 68. Iterations of large mass on site. Figure 69. Adapting precedents to site.

Figure 70. Fragmented sea walls. 

stairs.

121 Figure 72. Implementation of wetlands.

Figure 73. Section of boardwalk over wetlands. Figure 74. Massing of building uses with boardwalk system.

Figure 75. Elevation of concept.

Figure 76. Section of concept.

Figure 77. Orientation of $500 \mathrm{~m} 2$ masses.

Figure 78. Deck positioning.

Figure 79. Cardboard model of concept.

Figure 80. Concept Floor plans 1.

Figure 81. Perspective of concept on boardwalk.

Figure 82. Concept floor plans 2.

Figure 83. Concept facades.

Figure 84. Model of sliding doors.

Figure 85. Interaction between water levels and building.

Figure 86. Seating concepts.

Figure 87. Concept in flash flood.

Figure 88. Concept in rain.

Figure 89. Concept in sun.

Figure 90. Concept in wind.

Figure 91. Concept floor plans 3.

Figure 92. Concept floor plans 4. 